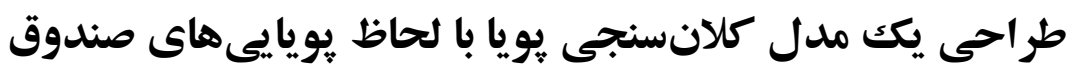 توسعه ملى براى اقتصاد ايران'
}

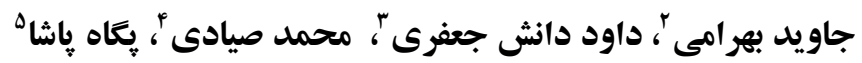

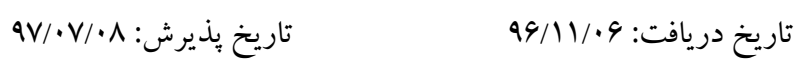

جكيده

مديريت در آمدهاى نفتى به نحوى كه زمينه ييشرفت و توسعه كشور را فراهم آورد،

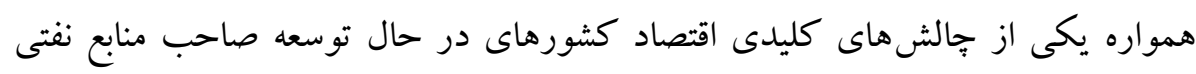

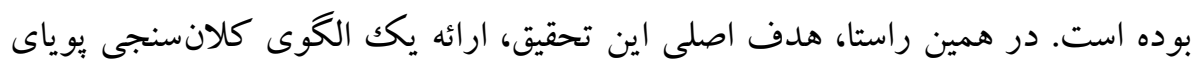

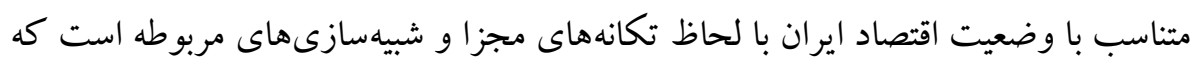
در آن به ارزيابى يويايىهاى صندوق توسعه ملى و تأثير آن بر متغيرهاى اقتصاد كلان

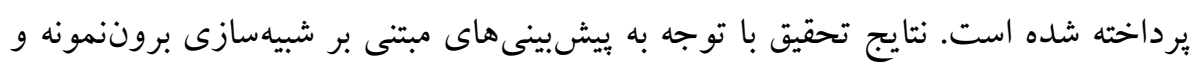

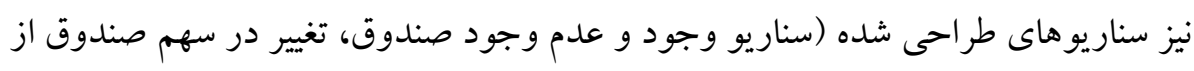

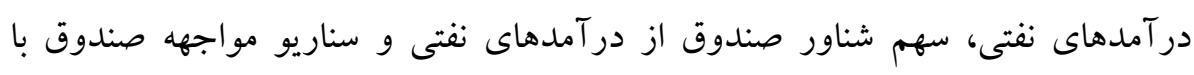

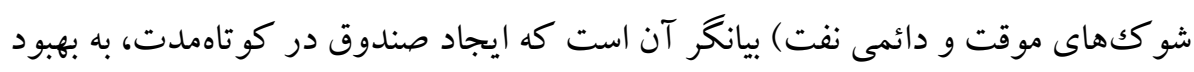
وضعيت متغيرهاى كلان اقتصادى كمكك نمى كند و آثار مثبت جنين سياستى در بلندمدات

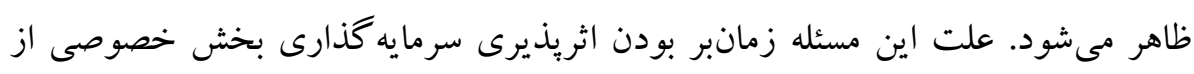
تسهيلات اعطايى صندوق توسعه ملى و و به تبع آن افزايش توليد بخش غيرنفتى در اقتصاد

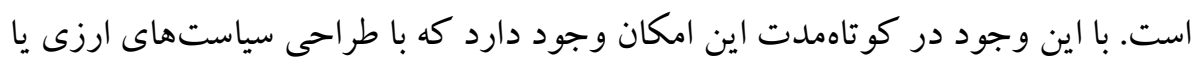

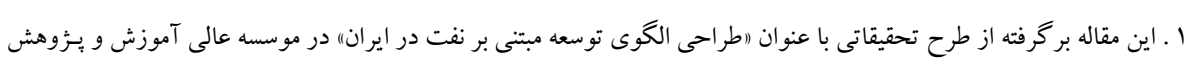
مديريت و برنامهريزى است است

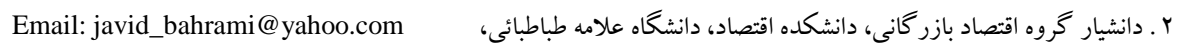

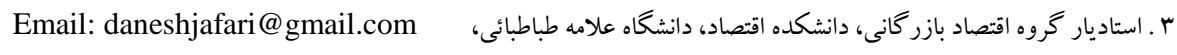

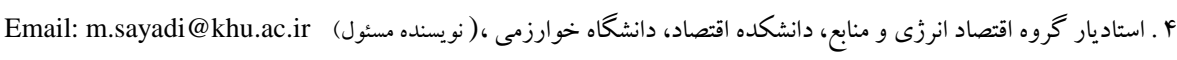

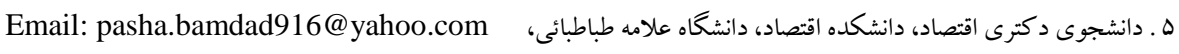


بودجهاى بتوان از افت اوليه سطح فعاليتهاى اقتصاد بر اثر وضع صندوق كاسته و بر بهبود

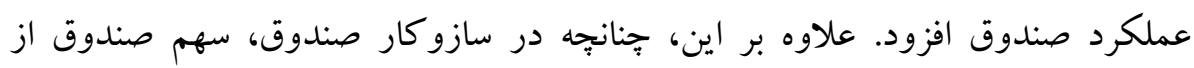
درآمدهاى نفتى شناور (اتخاذ سياست ضدسيكلى در تخصيص درآمدهاى نفتى به به

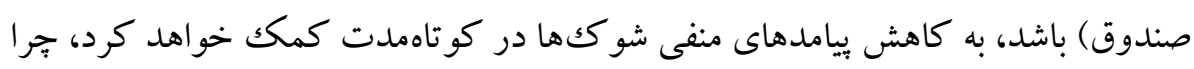

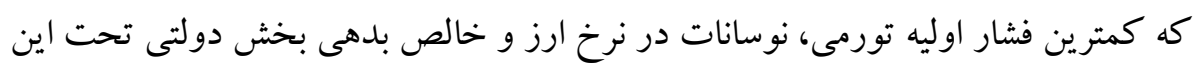
سناريو رخ مىدهد.

وازههاى كليدى: مدل كلان سنجى، شبيهازى تكانها، صندوق توسعه ملى. E27, Q43, C51 : JEL طبقلبندى 
ا. مقدمه

يكى از مشخصههاى اصلى اغلب كشورهاى درحالتوسعه نفتى، وابستخى بالاى اقتصاد به در آمدهاى حاصل از فروش منابع نفت و گاز است. اين مسأله موجب شده است است تا بودجهريزى ساليانه اين كشورها بدون وجود درآمدهاى نفتى، تقريباً غيرممكن شود.

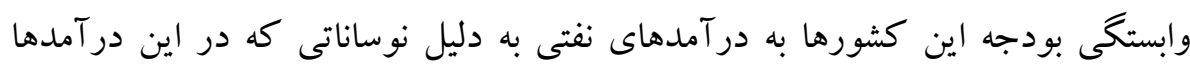

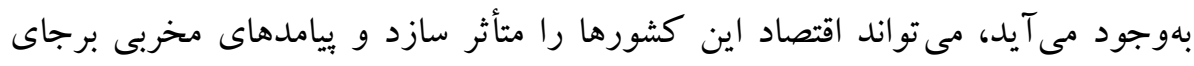

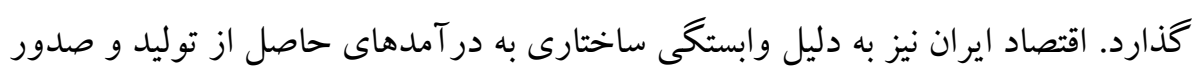

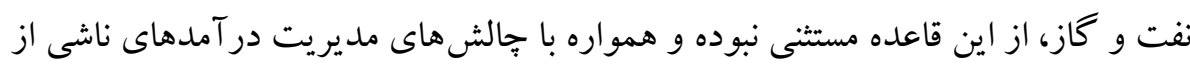

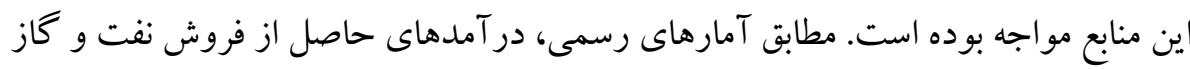

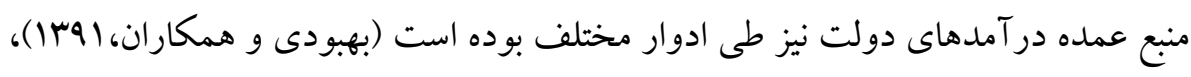
به طورى كه طى سالهاى برنامه اول، دوم، سوم، جهارم و ونجمم توسعه كشور، سهم

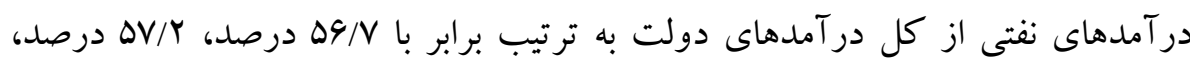

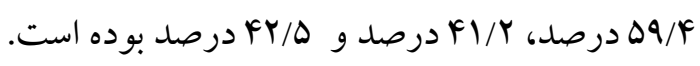
يكى از سازو كارهاى كاهش اثرات منفى سرايت نوسانات در آمدهاى نفتى به اقتصاد داخلى، تأسيس و راهاندازى صندوقهاى ثروت حاكميتى' است. صندوقهایى ارهاى ثروت حاكميتى در كنار اهدافى از قبيل كمكك به تثبيت اقتصاد، انجام بِ بسانداز بين نسلى و

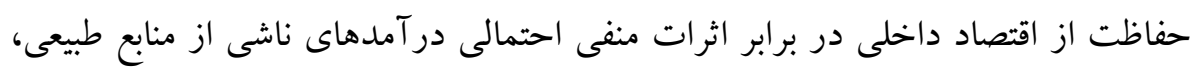
انجام سرمايه كذارى منابع مالى و كسب بازدهى بيشتر را نيز دنبال مى كنند (صيادى،

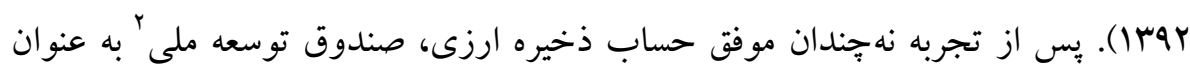
نمونهاى از صندوقهاى ثروت حاكميتى در سال ينجم توسعه كشور و با هدف تبديل بخشى از عوايد حاصل از فروش نفت و و كاز و و

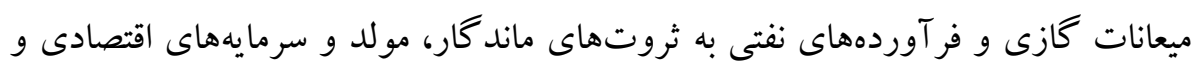

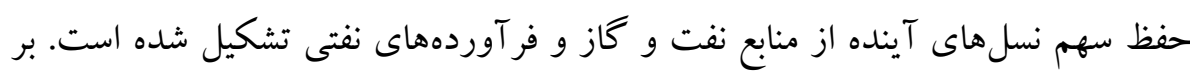




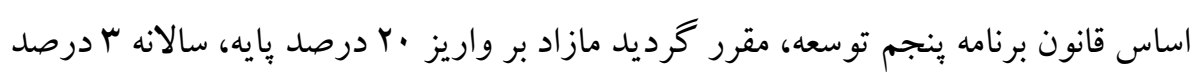

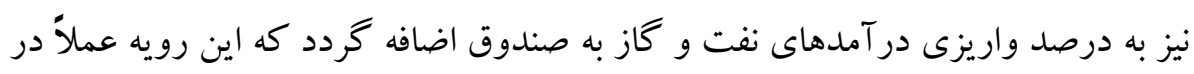

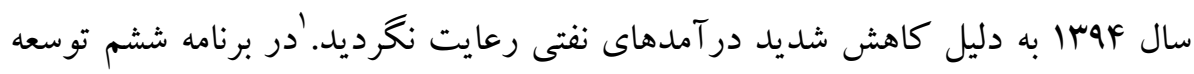

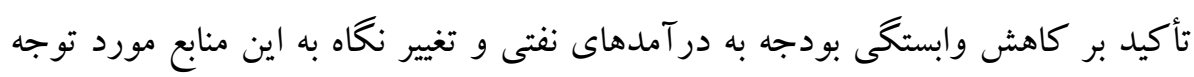

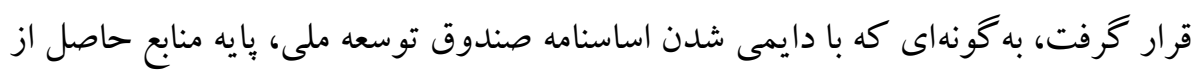

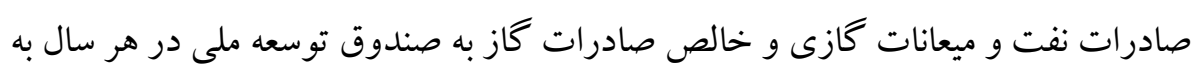

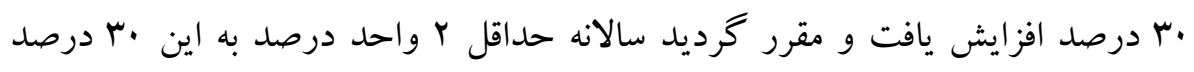
اضافه شود.

با عنايت به توضيحات فوق، ارزيابى عملكرد صندوق توسعه ملى در اقتصاد ايران مى تواند دلالتهاى سياستى مناسبى براى بهبود عملكرد و يا اصلاح روند آتى آن فراهم آورد. ضمن اينكه استفاده از يكك مدل كلان كه قدرت توضيح دهند

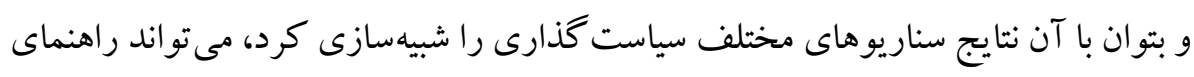

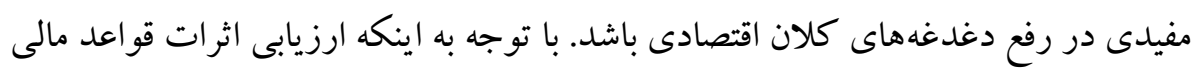

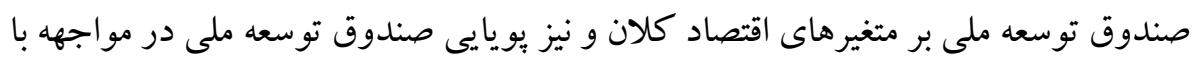

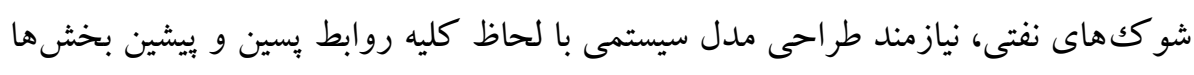

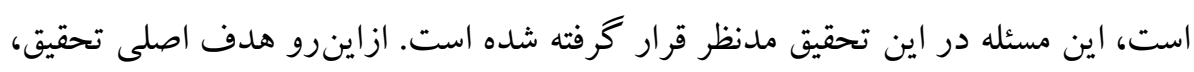

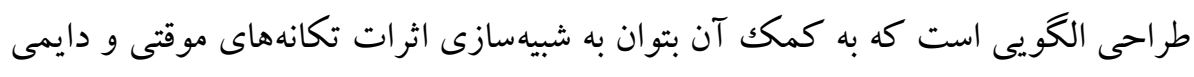

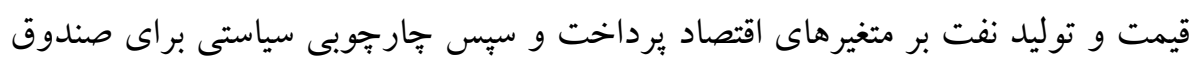

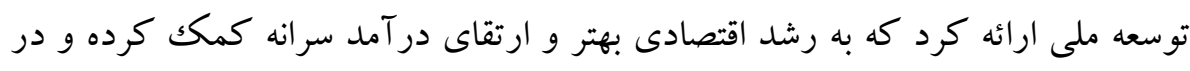

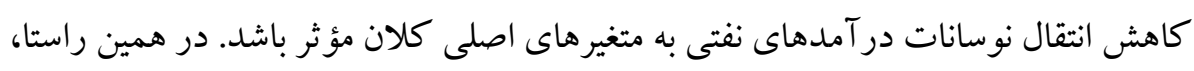
جهار سناريوى ا- وجود و عدم وجود صندوق، r- تغيير در سهم صندوق از در آمدهاى

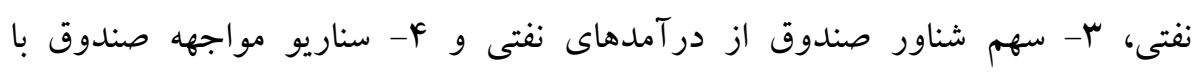

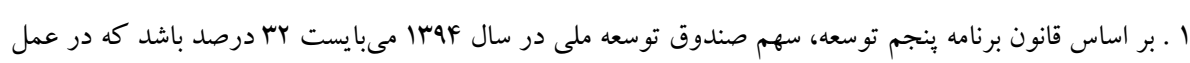

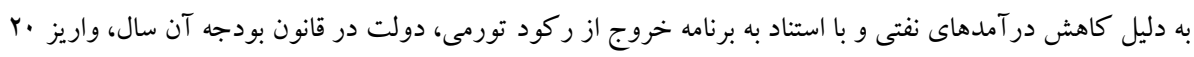


شوككهاى موقت و دائمى نفت) طراحى و اثرات هر يكك مورد تجزيه و تحليل قرار مى گيرد. خاطر نشان مىشود كه سناريوهاى طر احى شده در اين تحقيق، براى نخستين بار در ادبيات موضوعى تحقيق ارائه مىشود.

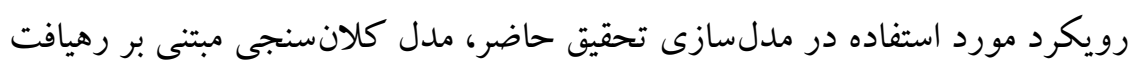

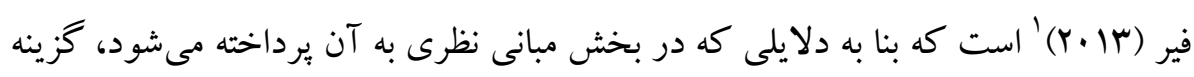

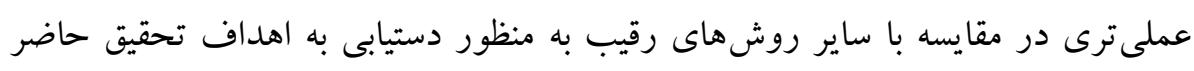

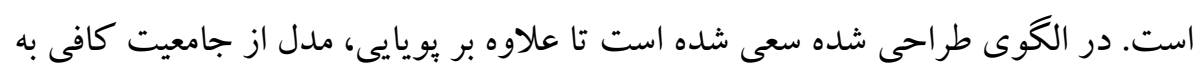

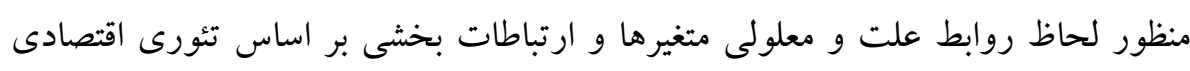

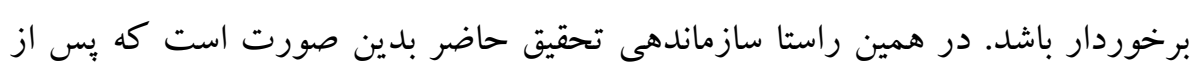

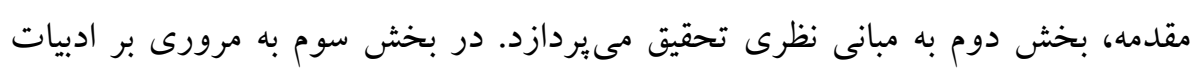

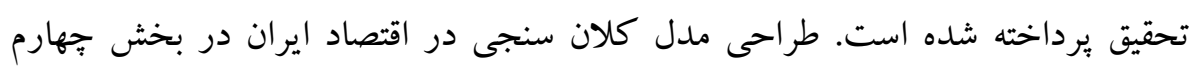

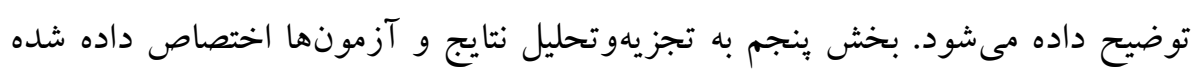

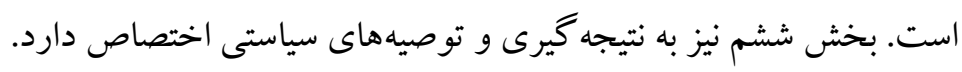

\section{r. مبانى نظرى تحقيق}

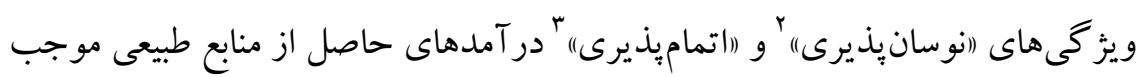

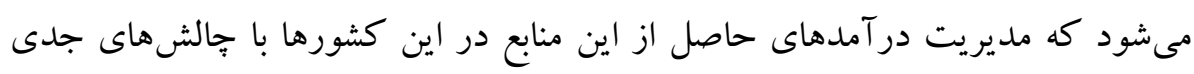

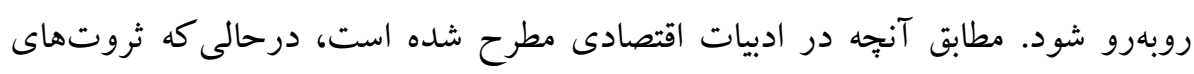

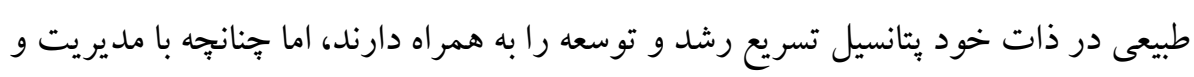

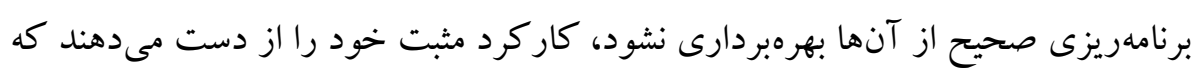

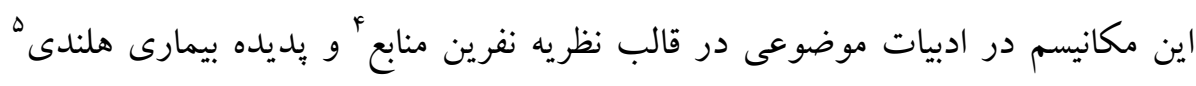
بر بـى شده است.

1. Fair

2. Volatility

3. Exhausability

4 . Resource Curse

5 . Dutch Disease 
در اين راستا، انتقال منابع طبيعى به بخش خصوصى، سرمايه گذارى درآمدهاى

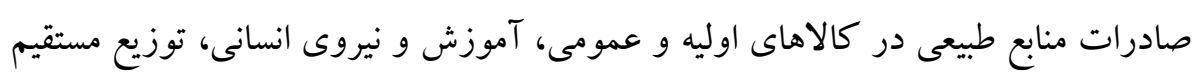
يول در اشكال مختلف و تأسيس صندوقهاى مختلف ذخيره در آمدهاى منابع طبيعى، از

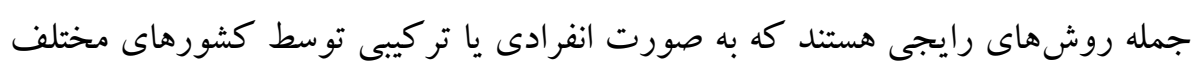

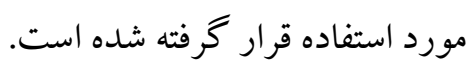
ييشينه ذخيرهسازى درآمدهاى حاصل از صادرات منابع طبيعى و يا فر آوردههاى

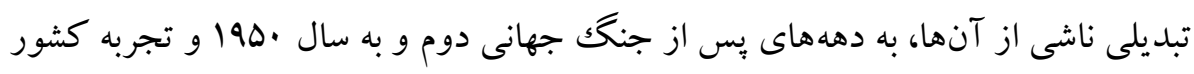

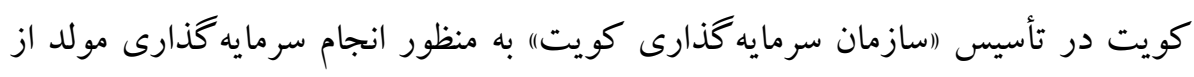
طريق مازاد درآمدهاى نفت در جهت كاهش وابستخى به ذخاير نفتى برمى گردد. بهور كلى صندوقهاى از نوع توسعه به يشتوانه ثروت ملى، در نوع اول خود (مدل ارتقاء

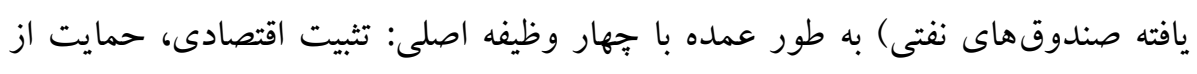

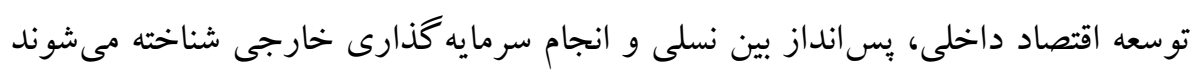

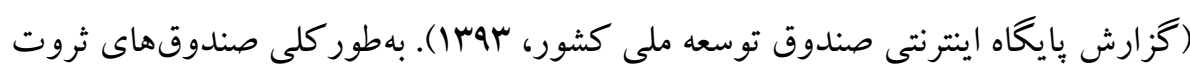
حكومتى را مى توان در سه دسته كلى دستهبندى نمود:

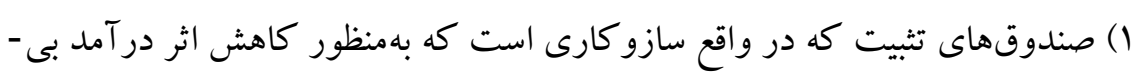
ثبات بر دولت و اقتصاد طراحى شده است. از ديخر اهداف آن، مىتوان به حمايت از

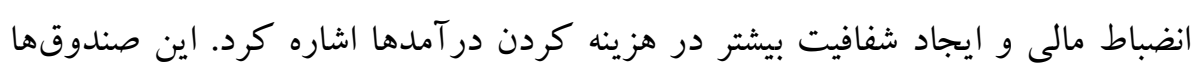

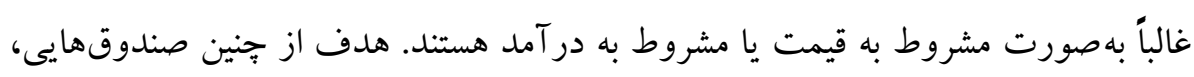

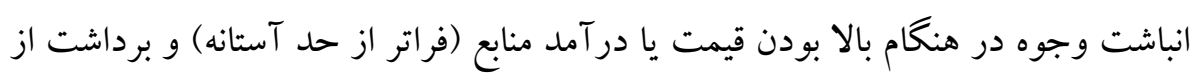

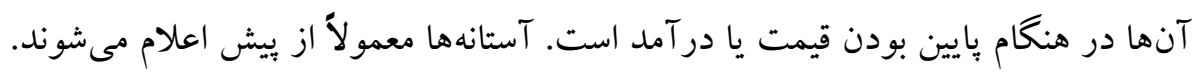
در واقع هدف از اين صندوقها، كاهش نوسانات منابع دائمى بودجه از طريق كاهش يا باني

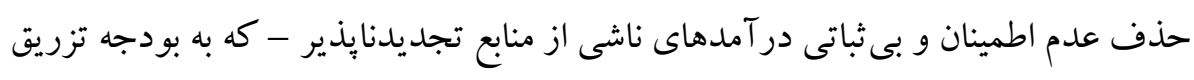

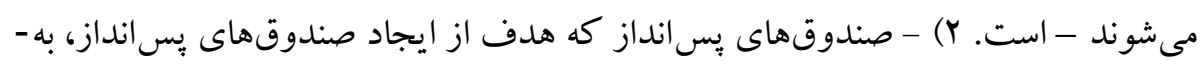

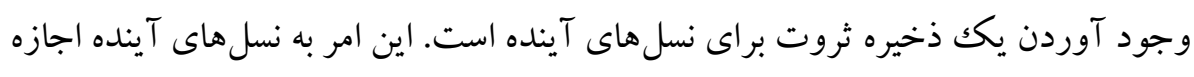

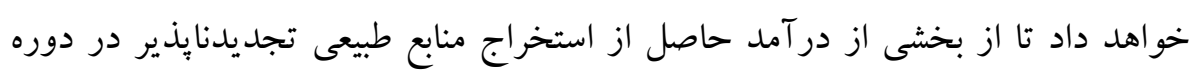


جارى بهرهمند شوند. صندوقهاى بِ انداز اغلب بر قواعد مستقلى تكيه دارند، به عنوان

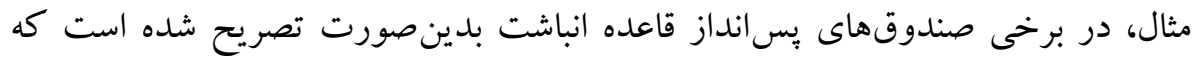

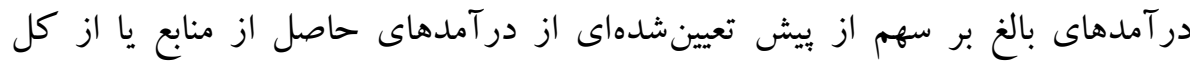

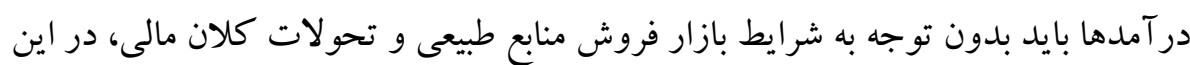

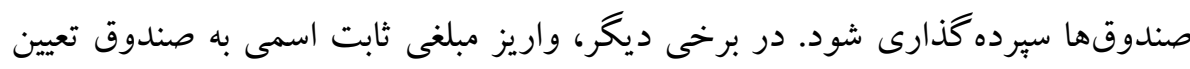

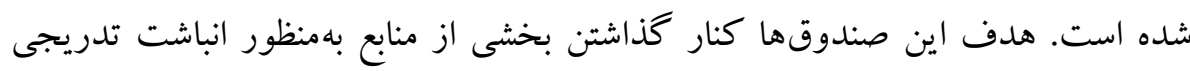

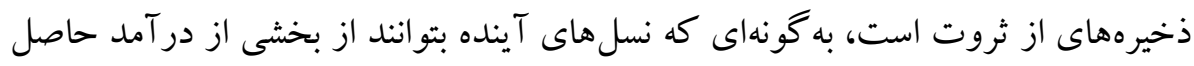

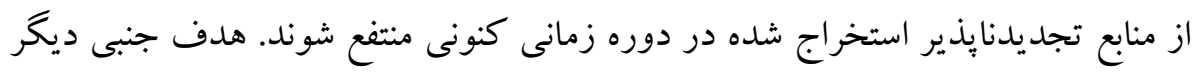

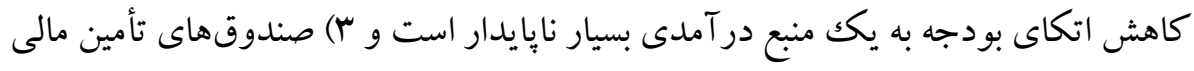
كه در آنها قو اعد عملياتى به گونهاى وضع مى شود كه تراز كل بودجه بهطور مؤثر تأمين مالى شود. صندوق نفت دولت نروز بر اين اساس فعاليت مى كند. بر اساس قو اعد موجود، در آمدهاى خالص نفت بايستى به صندوق منتقل شده و صندوق نيز كسرى غيرنفتى بودجه را از طريق يكك نقلوانتقال معكوس تأمين مالى كند. در عمل، اين مبلغ به صندوقى واريز مىشود كه تراز كل بودجه را تأمين مالى مى كند. اكر مازاد كلى بودجه وجود داشته باشد،

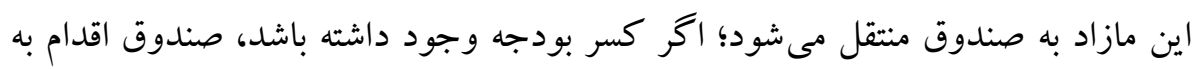

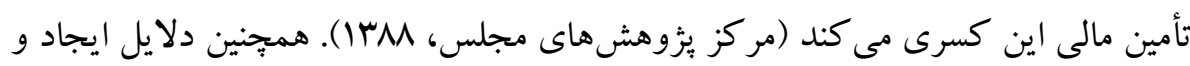
اهداف هر صندوق متفاوت است. برخى اهداف متداول صندوقها به شرح زير است:

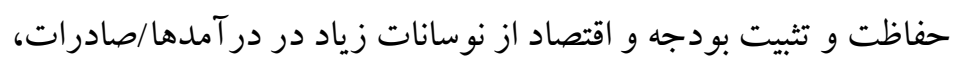

$$
\begin{aligned}
& \text { كم كردن وابستخى و تمركز بر صادرات كالاهاى غير بازيافتى، }
\end{aligned}
$$

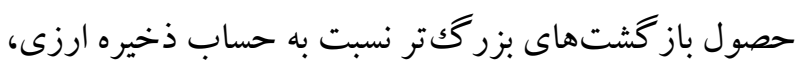

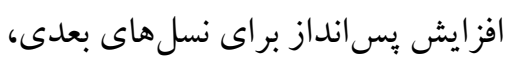

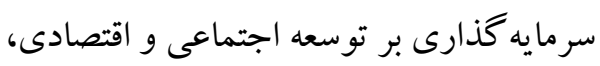

$$
\begin{aligned}
& \text { رشد سرمايه يايدار بلندمدت براى كشورها، و و برسي } \\
& \text { استراتزى سياسى }
\end{aligned}
$$


با عنايت به توضيحات فوق مى توان جنين عنوان نمود كه صندوق توسعه ملى ايران

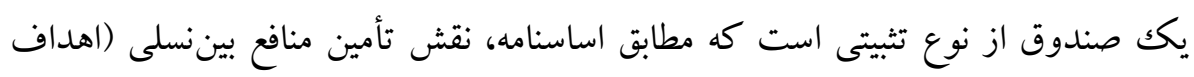

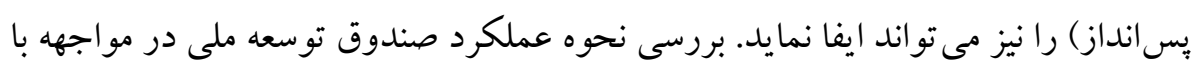
تكانها و نقش تثبيتى آن مىتواند دلالتهاى سياستى قابل اتكايى را براى سياست كذاران فراهم آورد. در ادامه در خصوص مبناى نظرى مدل تحقيق توضيحاتى ارائه مى شود: روش مورد استفاده در اين تحقيق، روش كلانسنجى (سيستم معادلات همزمان) است.

در اين خصوص جنين مىتوان كفت، سه انتخاب ممكن كه امروزه در مدلسازى و و تحليل

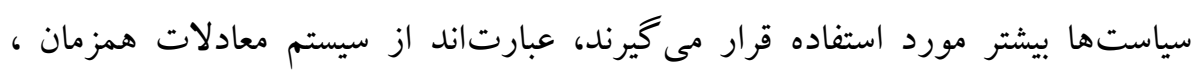

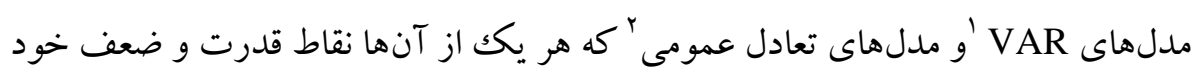

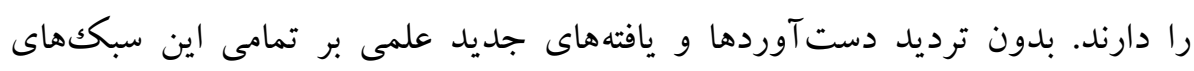

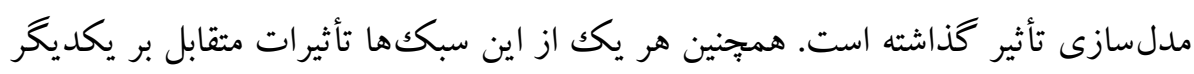
داشتهاند. مدلهاى خودتوضيحى بردارى ساختارى ؟ و آزمونهاى قيود بلندمدت و كو تاهمدت

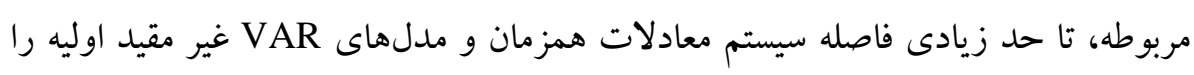

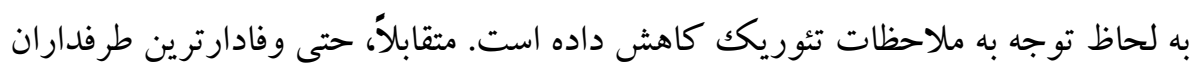
معادلات همزمان مثل رىسىفير "نيز، عليرغم طرفدارى بايدار از اين سبكى، تحت تأثير

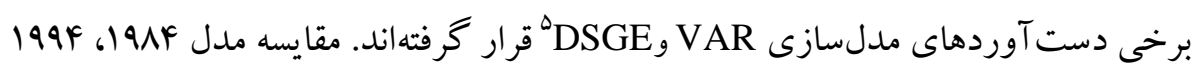

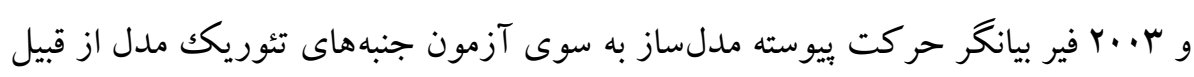
شكل گيرى عقلايى انتارات و توجه به مقوله مانايى است كه منجر به رد انتظارات عقلائي

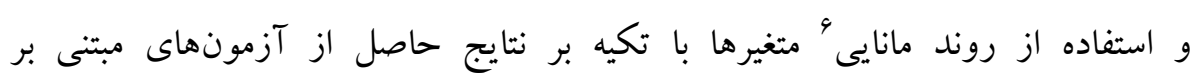

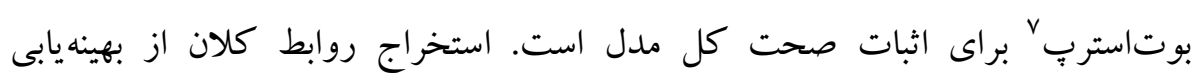

1. Vector Auto Regressive

2. General Equilibrium

3 . SVAR

4. Ray C. Fair

5. Dynamic Stochastic General Equilibrium

6 . Trend Stationary

7 . Bootstrap 
مطلوييت و حداكثر كردن سود در فضاى رقابت انحصارى در مدل r...r او، بدون شك

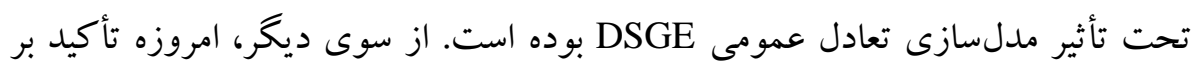

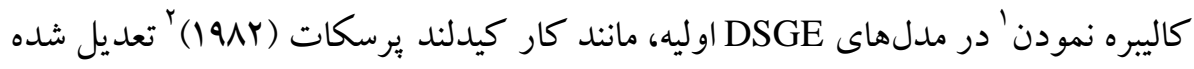

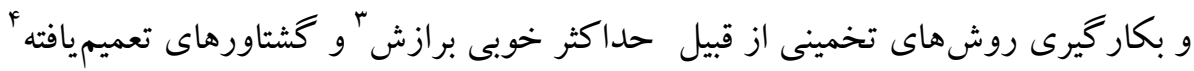

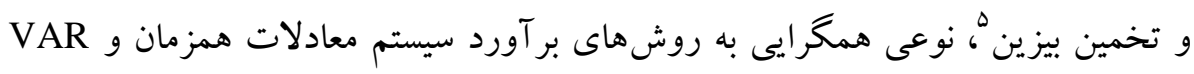
محسوب مىشود.

عليرغم اين، هنوز اين سه سبك مدلسازى داراى هويت مستقل و كاملاً متمايز از

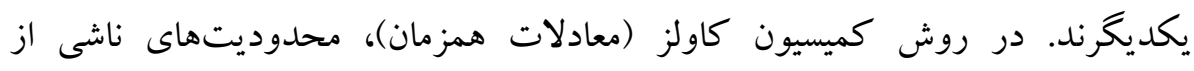
ملاحظات نظرى، مثل محدوديتهاى صفرى بر روى ضرايب يا محدوديتهاى مربوط به

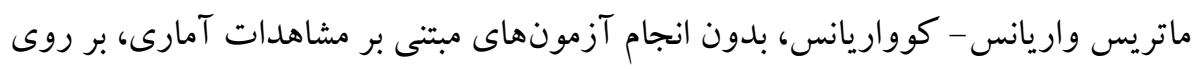
مدل وضع مىشود. در واقع در اين روش، ساختار مدل توسط تئورى، مشخص شده و از روشهاى آمارى مناسب براى تخمين استفاده مىشود. برعكس، در روش مدل مدلسازى

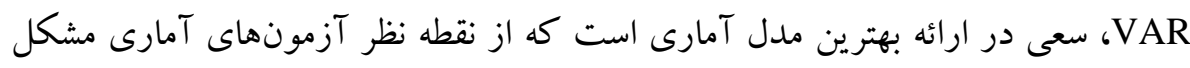

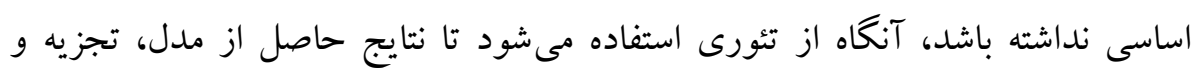
تحليل شود. در واقع در روش VAR، آمار نقشى فعال دارد درحالى كه در روش كميسيون كاولز نقش آمار انفعالى است.

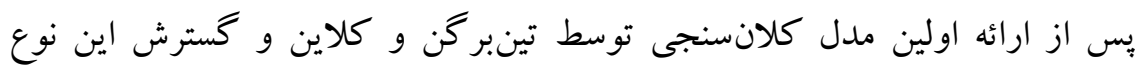
مدلها در مطالعات اقتصادسنجى بنياد كاولز، مدلهاى كلان سنجى به فراوانى توسط له

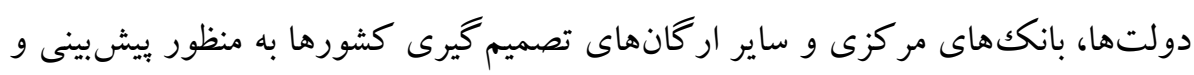

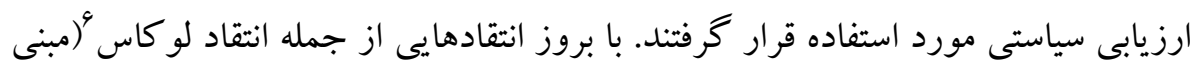
بر تغيير پارامترهاى سيستم همزمان با تغيير متغيرهاى برونزا) و مشكل شناسايى سيستم

1. Calibration

2 . Kydland, Prescott

3 . Maximum Likelihood

4. Generalized Method of Moments

5 . Baysian

6. Lucas Critique 
(سيمز، ••191)، استفاده از مدلهاى تعادل عمومى، VAR و مانند آنها نيز مرسوم شده است. با وجود اين، محدوديت در استفاده از متغيرهاى بيشتر در مدلهاى مزبور، فراهم

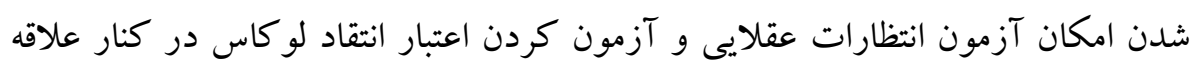

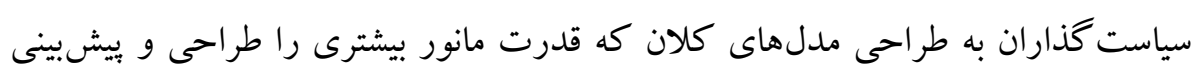

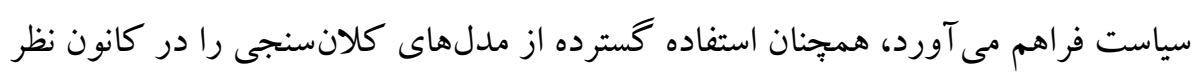

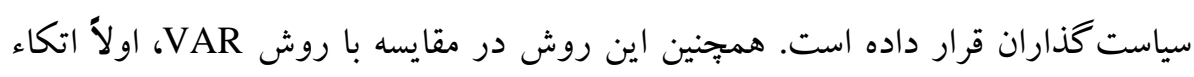
كمترى به دادههاى آمارى دارد. هنگامى كه از دقت دادههاى آمارى مطمئن نبوده و نيز آمارها كاملاً به روز نيستند، اعتماد به محدوديتهاى نظرى توجيه بيشترى ميى يابد. اينكه

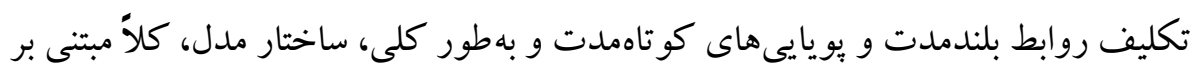

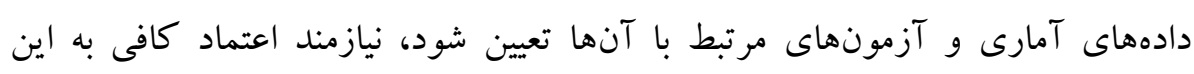
اطلاعات است. در غير اين صورت، محدوديت هايى كه توجيه نظرى داشته باشند، موجه تر

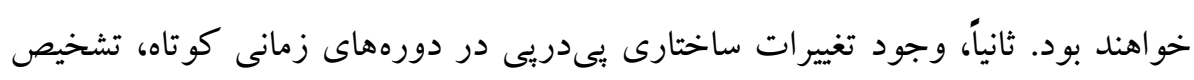

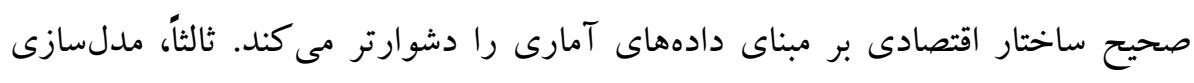

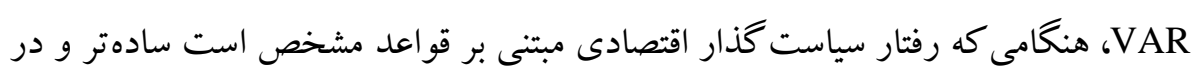

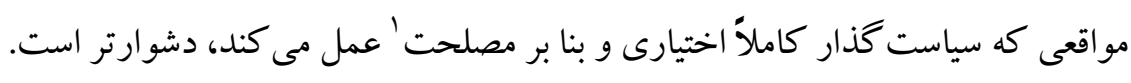

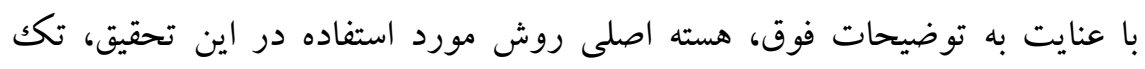

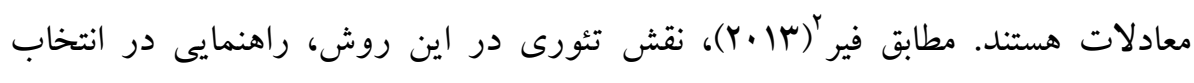
متغيرهاى وابسته و مستقل معادلات تصادفى مدل است. زمانى كه متغيرها شناسايى شدند،

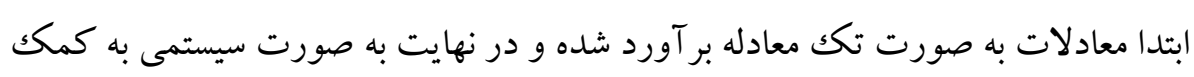

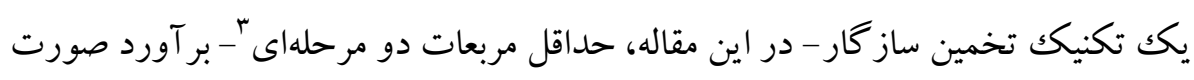

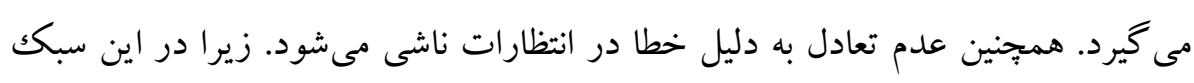
مدلسازى، فرض صفر بر اين اساس است كه انتظارات عقلايى نيستند. به منظور داشتن

1. Discretion

2. Macroeconometric Modeling, Fair

3. 2SLS 
بنكاهى با انظظارات عقلايى بنگًاه بايد از مسئله بهينه سازى تمامى بنگاههاى ديخر و خانوارها آكاهى داشته باشد. فرض شده است كه بنگًاهها جِنين دانشى ندارند (مثلاً به مدل كامل دسترسى ندارند) و ازاينرو در تشخيص انتظارات مى توانند با خطا روبهرو شوند. لازم به

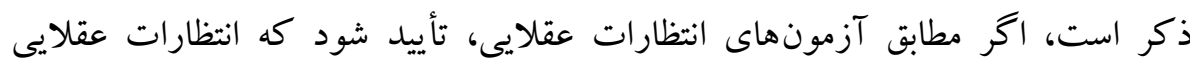

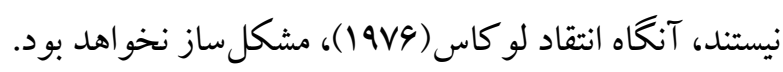

در نهايت اينكه، مبناى نظرى انتخاب برخى متغيرها و فرم روابط و معادلات در مدل

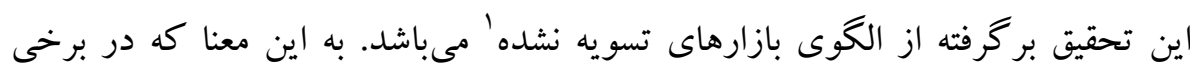

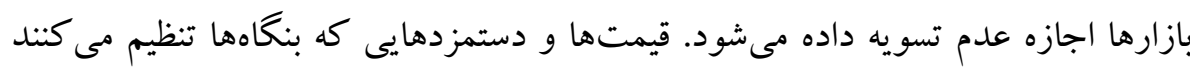

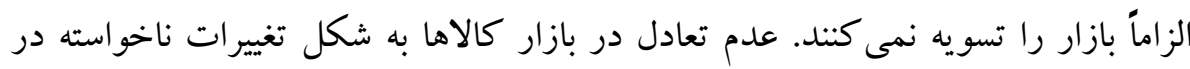

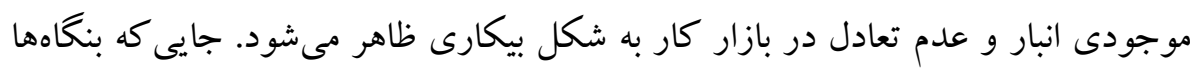

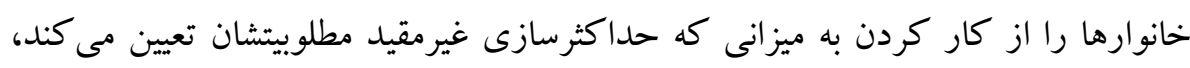
محروم مى كنند. عدم تعادل، از خطاهايى كه در انتظارات است ناشى مى شود. براى بر اينكه

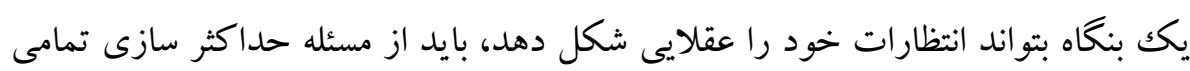
بنگاههاى ديخر و خانوارها مطلع باشد. فرض مى شود كه بنگاهها هنين دانشى ندارند (مدل

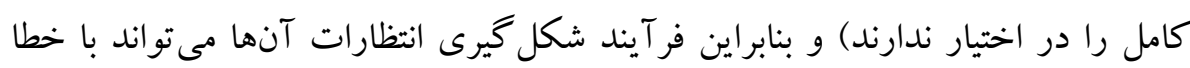

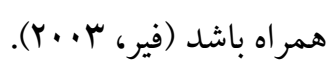

\section{r. ادبيات موضوعى تحقيق}

با بررسى مطالعات انجام شده در ادبيات موضوعى به برغيوى از مطالعات مرتبط با

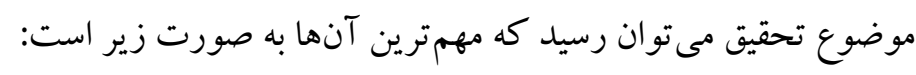




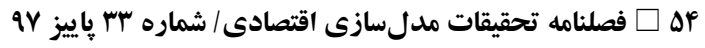

\begin{tabular}{|c|c|c|c|c|}
\hline نتايج عمده & روش مورد استفاده & هدف تحقيق & عنوان تحقيق & نويسنده (سال) \\
\hline 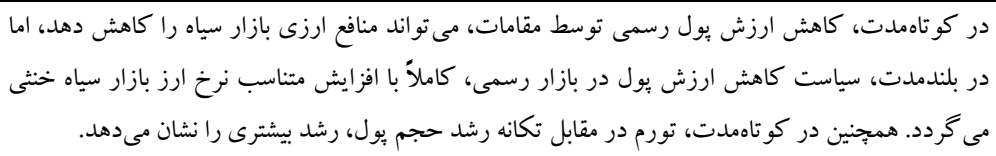 & 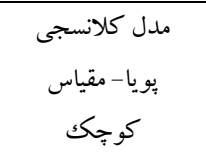 & 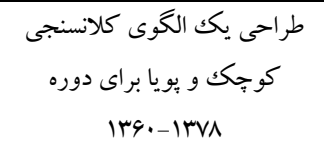 & 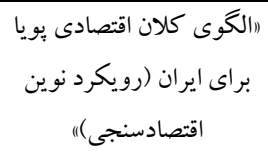 & خيابانى (Ir/I) \\
\hline 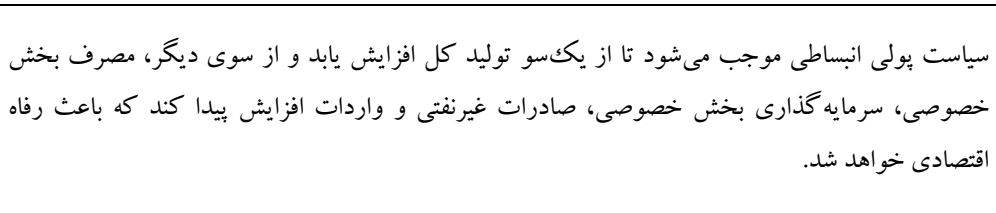 & 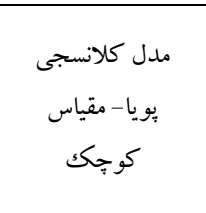 & 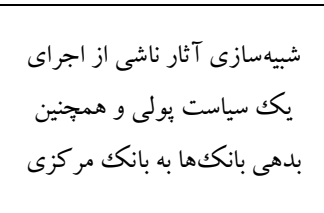 & 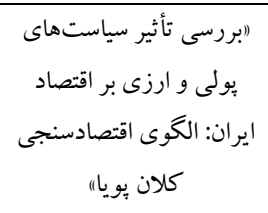 & نوفرستى (IrAF) \\
\hline نتايج نشان از سرعت تعديل بايين (ميانكين وقفه زمانى بالا) براى قيمتها و دستمزدها و سرعت تعديل بالا & شبيهسازى مدل با & 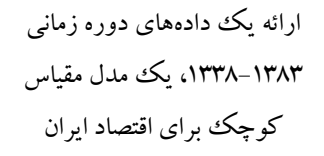 & 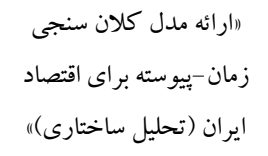 & 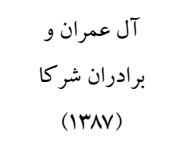 \\
\hline 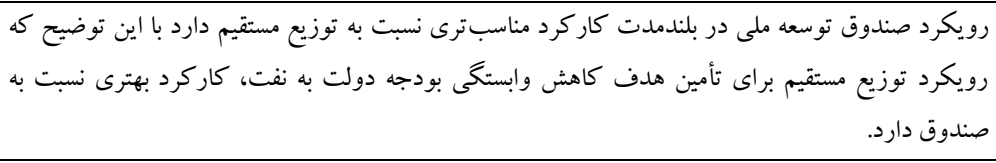 & مدل 'CGE & 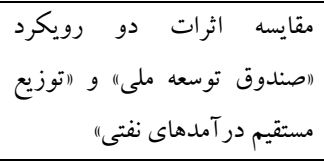 & تفوزيع مستقيم در آمدهاى ملى ياى دور رويكرد مقايساى" & 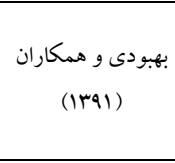 \\
\hline 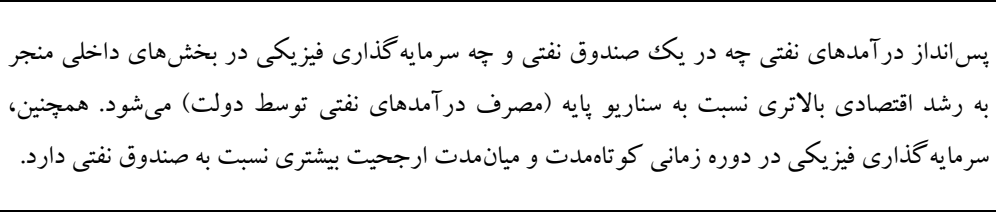 & 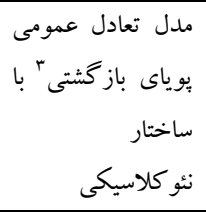 & 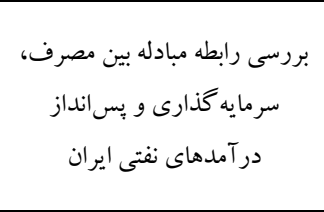 & "خصيص در آمد نفت در زينهاى مختلف & صبوحى (r) بر ب (r) \\
\hline
\end{tabular}

1. Computable General Equilibrium

2 . Barkhordar and Saboohi

3 . Recursive Dynamic Computable General Equilibrium 
طراحى يك مدل كلانسنجى بويا با لحاظ بويايىهاى صندوق توسعه ملى براى اقتصاد ايران

\begin{tabular}{|c|c|c|c|c|}
\hline نتايج عمده & روش مورد استفاده & هدف تحقيق & عنوان تحقيق & نويسنده (سال) \\
\hline 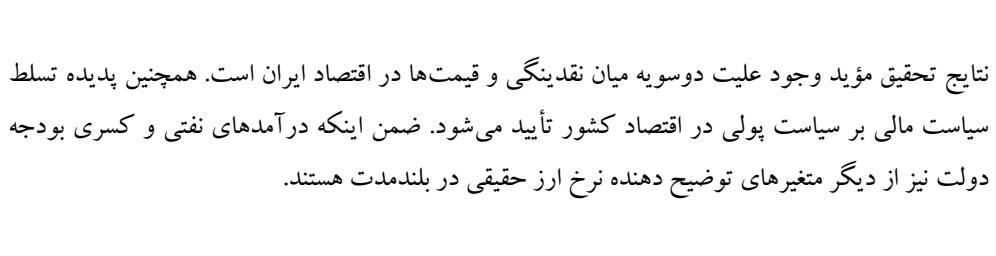 & مدل كلانسجى & 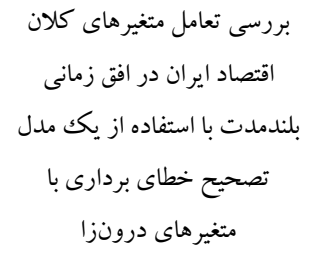 & 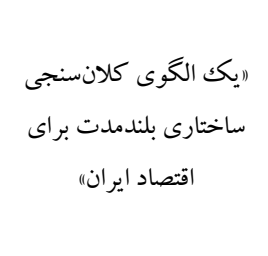 & 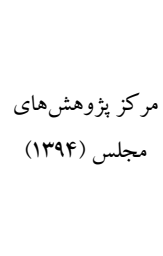 \\
\hline 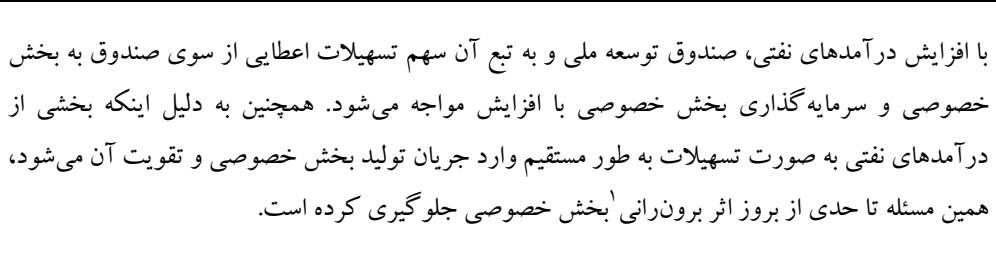 & مدل (DSGE) & 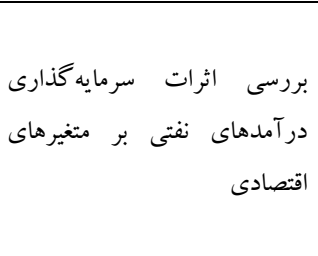 & 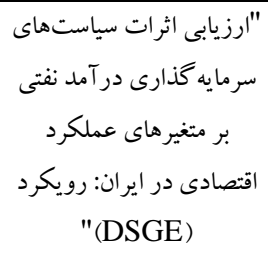 & 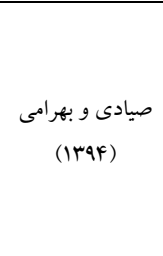 \\
\hline 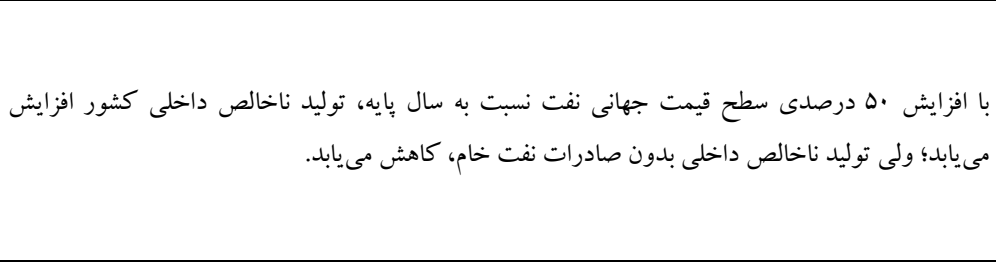 & مدل (DCGE) & 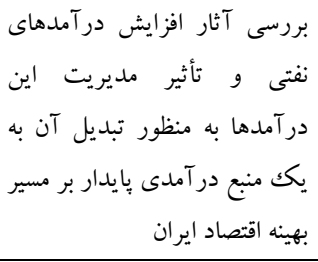 & 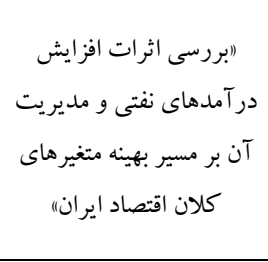 & 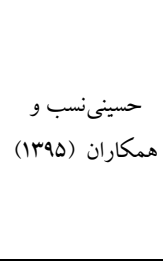 \\
\hline آثار مستقيم تحريمها تنها در خصوص رشد اقتصادى و رابطه مبادله معنادار است. & 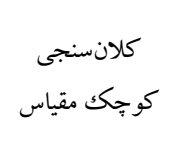 & تأثير تحريمها بر متغيرهاى كلان & 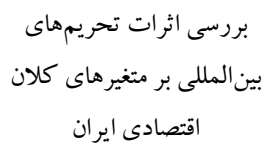 & يوسفى ديندارلو و \\
\hline
\end{tabular}

\section{Crowding Out Effect}




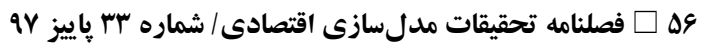

\begin{tabular}{|c|c|c|c|c|}
\hline نتايج عمده & روش مورد استفاده & هدف تحقيق & عنوان تحقيق & نويسنده (سال) \\
\hline 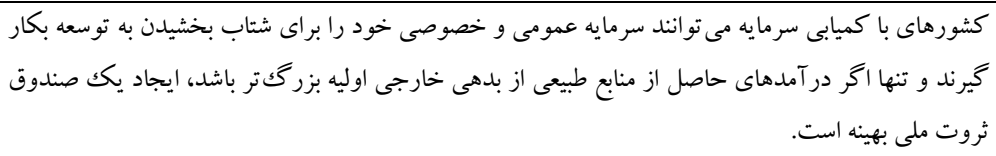 & كاليبره كرده تابع & 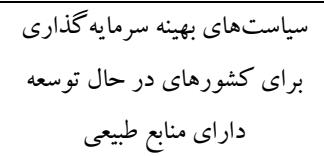 & 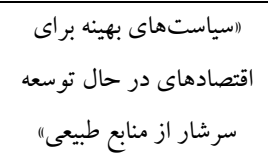 & 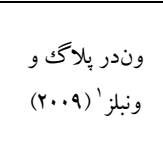 \\
\hline 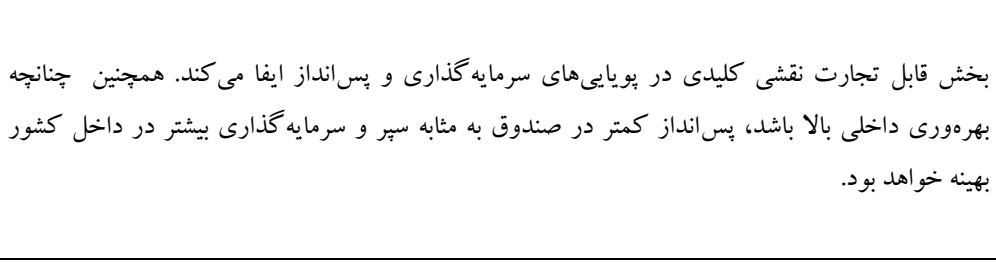 & 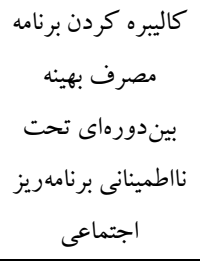 & كررسى سياست مالى گروهاى نفت خيز & 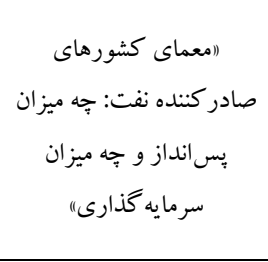 & جريف و حسنف \\
\hline 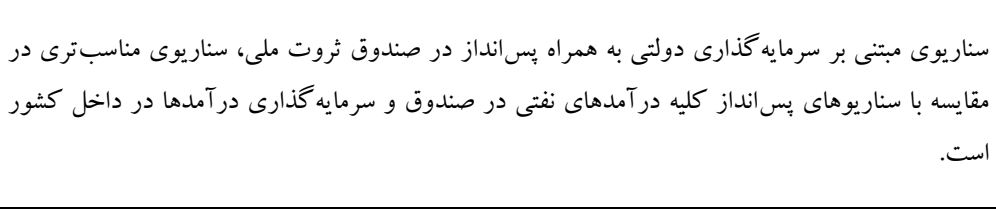 & مدل DSGE & 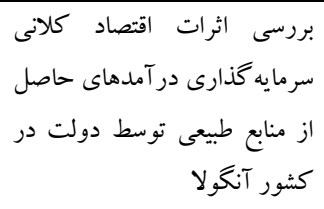 & 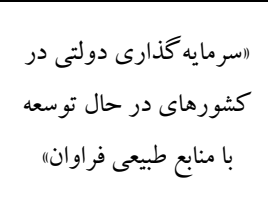 & 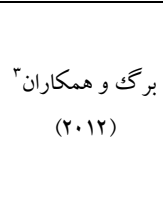 \\
\hline 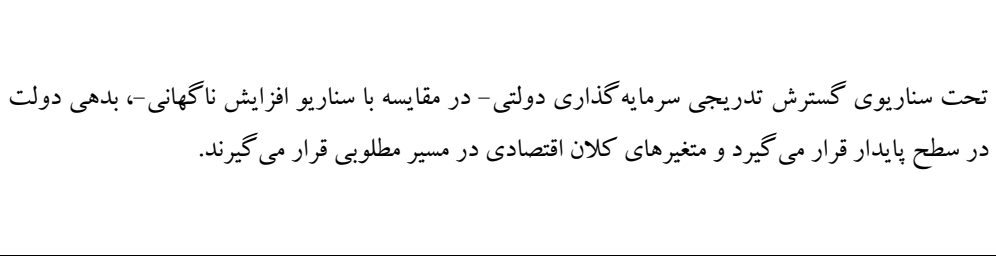 & مدل DSGE & 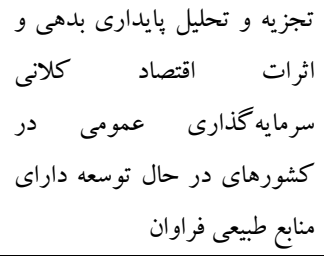 & 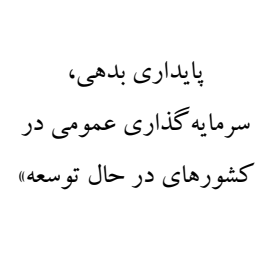 & 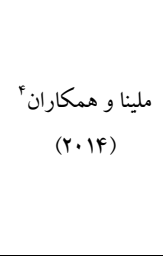 \\
\hline
\end{tabular}

1. Frederick van der Ploeg and Anthony J. Venables

2. Cherif and Hasanov

3. Berg

4. Giovanni Melina et al. 
bY

\begin{tabular}{|c|c|c|c|c|}
\hline نتايج عمده & روش مورد استفاده & هدف تحقيق & عنوان تحقيق & نويسنده (سال) \\
\hline يرداختىهاى صندوق آلاسكا منجر به افزايش نابرابرى در آمدى در كو تاممدت و بلندمدت شده است. & 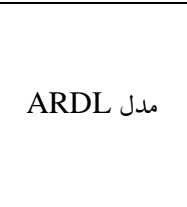 & در آزمون تجربى اثر عايدى صندى آلاسكا بر نابرابرى & 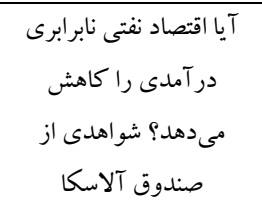 & بكوزمينكسى و \\
\hline 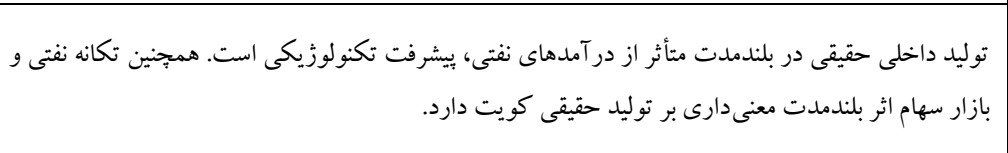 & مدل كلانسنجى & 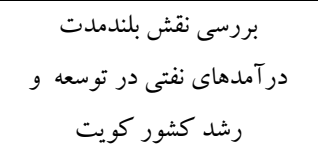 & 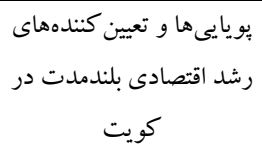 & 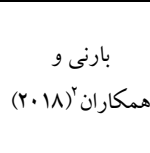 \\
\hline
\end{tabular}

1 . Kozminski, K., \& Baek 2. Burney 
با بررسى مطالعات انجام شده مشاهده مىشود به رغم اينكه تلاشهاى خوبى براى

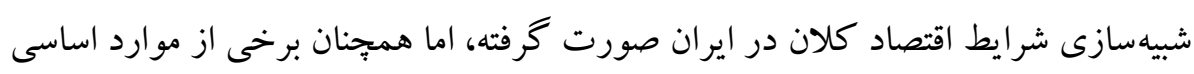
از جمله مدل سازى بويايى صندوق توسعه ملى با لحاظ روابط اصلى با ساير بخشها ها و نيز

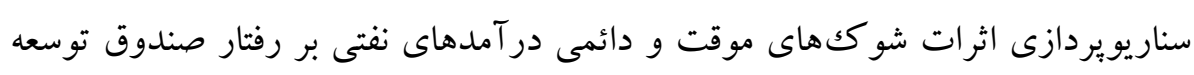

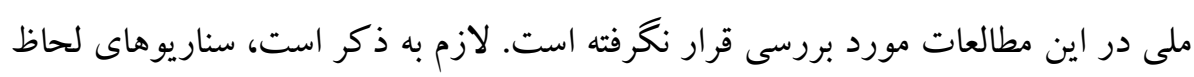

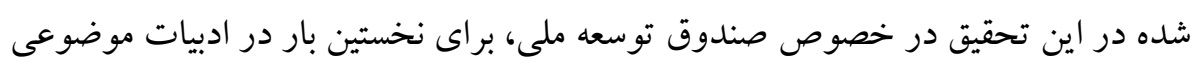

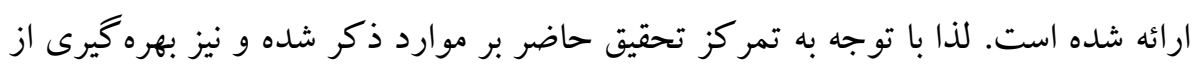
روش كلانسنجى در مدلسازى، تحقيق حاضر داراى نوآورى نسبت به ساير مطالعات موجود است.

\section{† أ. طراحى مدل كلان سنجى متناسب با اقتصاد ايران}

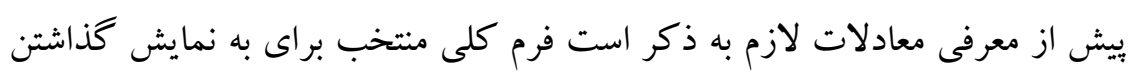
ارتباطات بلندمدت و كو تاهمدت در اكثر معادلات، فرم تصحيح خطا است. در فرم تصحيح

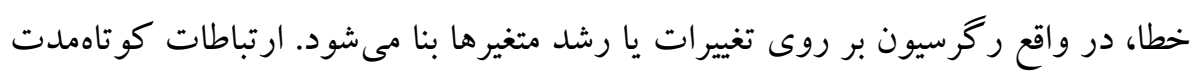
توسط ضرايب مشخص مىشوند و جز تصحيح خطا انحر افات از رابطه بلندمدت ران ران نشان

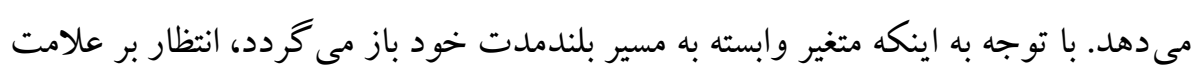

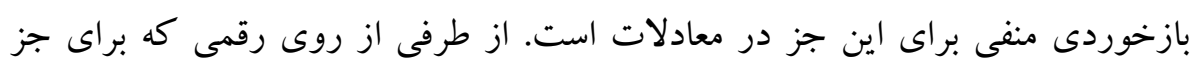

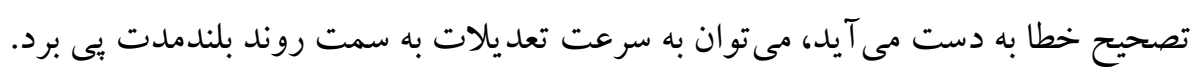

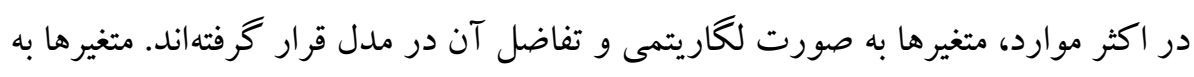

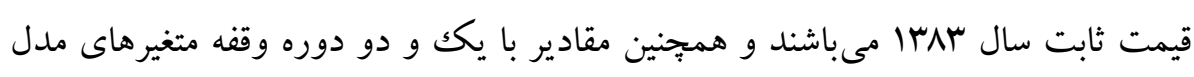
بهنوان متغيرهاى ابزارى در روش 2SLS مورد استفاده قرار گر فتهاند.

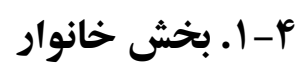

مطابق تئورىهاى اقتصادى، مصرف يكى انوار مهممترين متغيرهاى تصميم در مسأله

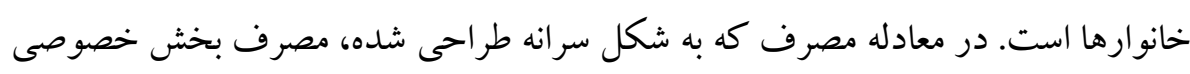

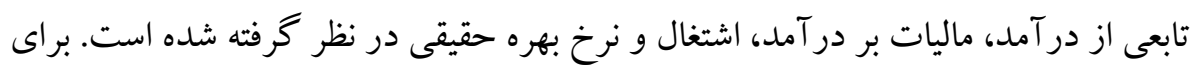
انعكاس تفاوتهاى موجود در رفتار كوتاهمدت و بلندمدت مصرف، بر مبناى بايههاى 
نظرى مختلف، اشكال متنوعى از مدلهاى توزيع وقفه' به كار گرفته مىشود. به دليل عدم دسترسى به اطلاعات قابل اطمينان در مورد در آمد قابل تصرف، توليد ناخالص غيرنفتى به عنوان جايگزين قرار داده شده است و با لحاظ متغير ماليات بر درآمد حقيقى تلاش شده

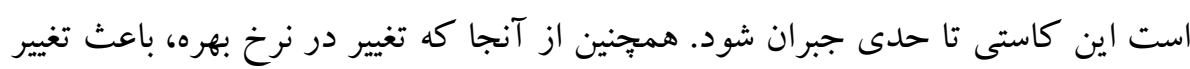

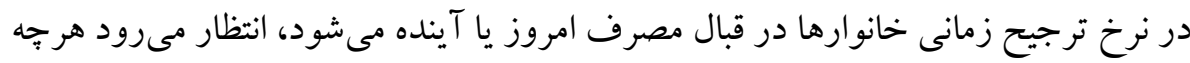
نرخ بهره بيشتر باشد، خانوارها مصرف آينده را جايگزين مصرف فعلى نمايند. به عبارت

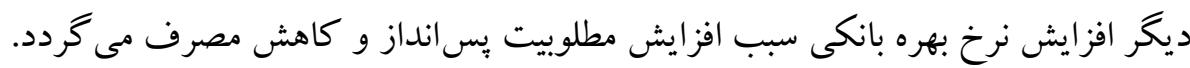

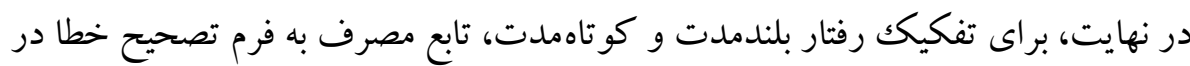

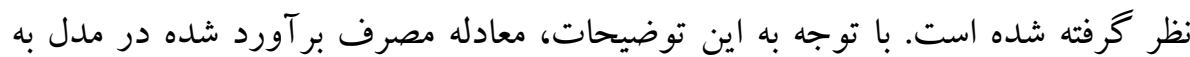
صورت زير مىباشد.

$\left.\operatorname{dlog}\left(\left(\frac{\mathrm{pc}}{\mathrm{pop}}\right)_{\mathrm{t}}\right)=2.6-0.64 \log \left(\left(\frac{\mathrm{pc}}{\mathrm{pop}}\right)_{\mathrm{t}-1}\right)+0.67 \log \left(\left(\frac{\mathrm{ynoil}}{\mathrm{pop}}\right)_{\mathrm{t}-1}\right)-0.18 \log \left(\frac{\mathrm{it}}{\mathrm{p} \text { pop }}\right)_{\mathrm{t}-1}\right)+0.11 \log \left(\mathrm{l}_{\mathrm{t}-1}\right)+$ $0.93 \mathrm{~d} \log \left(\left(\frac{\text { ynoil }}{\text { pop }}\right)_{\mathrm{t}}\right)-0.09 \mathrm{~d} \log \left(\left(\frac{\mathrm{it}}{\mathrm{p} * \text { pop }}\right)_{\mathrm{t}}\right)+0.24 \mathrm{~d} \log \left(\left(\frac{\text { ynoil }}{\text { pop }}\right)_{\mathrm{t}-1}\right)-0.24 \mathrm{~d}\left(\mathrm{rr}_{\mathrm{t}-1}\right)$ مصرف بخش خصوصى، ynoil توليد غيرنفتى، it ماليات بر درآمد، pc

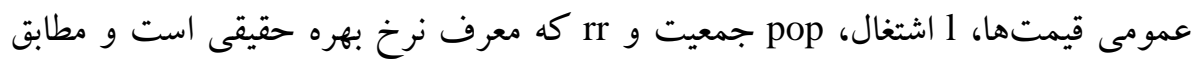
رابطه زير محاسبه گرديده است:

$$
\mathrm{rr}=\frac{1+\frac{\mathrm{ir}}{100}}{1+\Delta \log (\mathrm{p}(-1))}-1
$$

$$
\begin{aligned}
& \text { ir نرخ بهره اسمى است. } \\
& \text { r-r-r بخش بنغاه }
\end{aligned}
$$

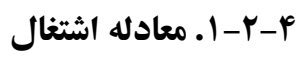

با توجه به اينكه بازار كار در اين مدل در شرايط عدم تسويه طراحى شده است، لذا نياز به طراحى هر دو سمت عرضه و تقاضاى بازار نيست. زيرا قيمتها از تقابل عرضه و و تقاضاى ذهنى افر اد حاصل نشده و همواره سمت تقاضاى بازار حاكم شده و سيس قيمتها بر اساس قدرت جانهزنى طرفين مشخص مى گردند. در بازار كار ميزان اشتغال به شكل

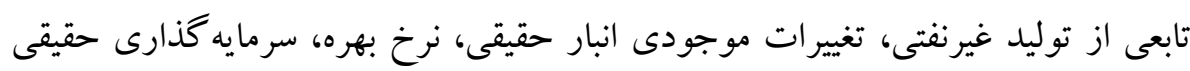


دولتى و دستمزد حقيقى در نظر گرفته مىشود. همجينين با توجه به اثرى كه نرخ بهره از

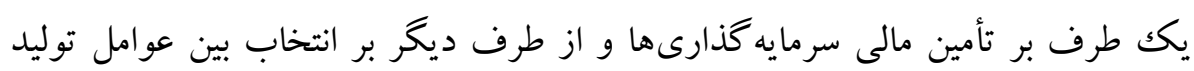

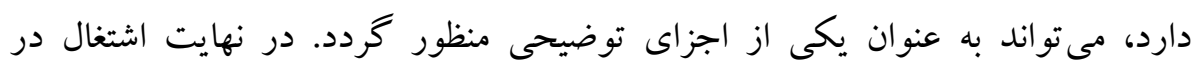

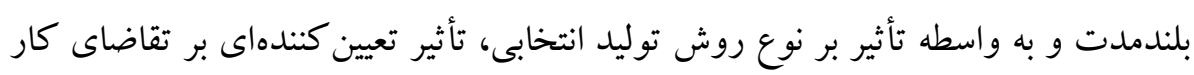

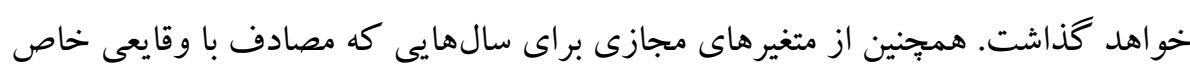

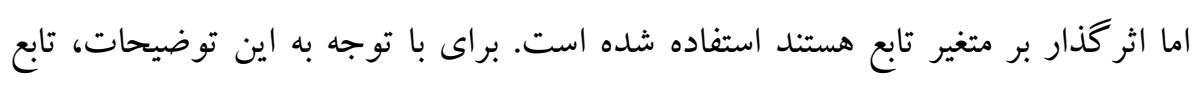
تقاضاى نيروى كار به صورت زير تصريح شده است:.

$\operatorname{dlog}\left(\mathrm{l}_{\mathrm{t}}\right)=0.56-0.04 \log \left(\mathrm{l}_{\mathrm{t}-1}\right)-0.03 \log \left(\left(\frac{\mathrm{w}}{\mathrm{p}}\right)_{\mathrm{t}-1}\right)-5.45 \mathrm{E}-$ $08\left(\right.$ inv $\left._{\mathrm{t}-1}\right)+0.08 \mathrm{~d} \log \left(\right.$ ynoil $\left._{\mathrm{t}}\right)-0.05 \mathrm{~d} \log \left(\mathrm{ir}_{\mathrm{t}}\right)+$ $0.02 \mathrm{~d} \log \left(\mathrm{ig}_{\mathrm{t}-1}\right)+0.04 \mathrm{~d}(\mathrm{~d} 84)+0.03 \mathrm{~d}(\mathrm{~d} 91)$

W شاخص دستمزد، ig مخارج سرمايهاى دولت و inv، تغييرات در موجودى انبار است كه به عنوان باقيمانده تراز توليدى اقتصاد كلان و از رابطه زير محاسبه مىشود: $\operatorname{inv}_{\mathrm{t}}=\mathrm{y}_{\mathrm{t}}-\mathrm{pc}_{\mathrm{t}}-\mathrm{gc}_{\mathrm{t}}-\mathrm{ip}_{\mathrm{t}}-\mathrm{ig}_{\mathrm{t}}-\mathrm{nx}_{\mathrm{t}}$

به عبارتى تغييرات در موجودى انبار از تفاضل مخارج مصرفى و سرمايهاى خصوصى

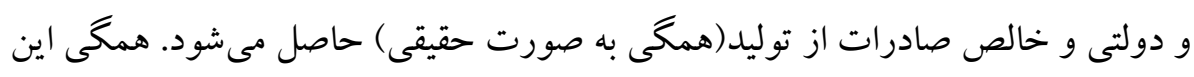
متغيرها در داخل مدل و توسط معادلات يا تساوىها به دست مى آيند كه هر كدام در بخشهاى مربوطه توضيح داده خو اهند شد.

\section{P}

در اين معادله تابع توليد غيرنفتى از نوع كاب داكلاس بالبا بازده ثابت نسبت به مقياس معرفى شده است.

$$
\text { ynoil }=\mathrm{A}(\mathrm{Kno})^{\theta_{1}} \mathrm{~L}^{\left(1-\theta_{1}\right)}
$$

ميزان سرمايه انباشته شده(ذخيره سرمايه) نيز از عوامل تعيين كننده توليد غيرنفتى است.

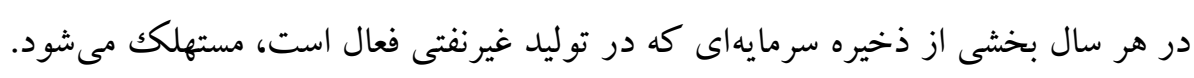

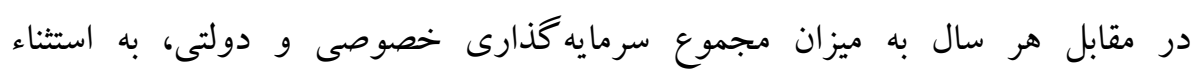


سرمايه گذارى دولت در نفت و كاز، به ذخيره سرمايه دولت در سال قبل افزوده مىشود.

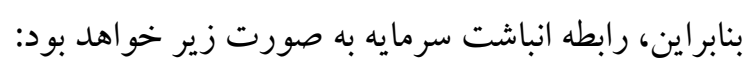

$$
\mathrm{Kno}_{\mathrm{t}}=\left(1-\mathrm{dep}_{\mathrm{t}}\right) \mathrm{kno}_{\mathrm{t}-1}+\mathrm{ip}_{\mathrm{t}}+\mathrm{ig}_{\mathrm{t}}-\mathrm{ogsi}_{\mathrm{t}}
$$

كه در اين رابطه، Kno، ذخيره سرمايه مورد استفاده در توليد غيرنفتى بر حسب قيمت

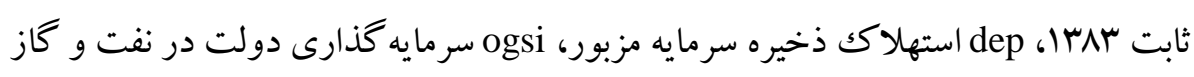

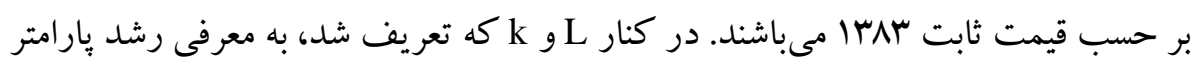

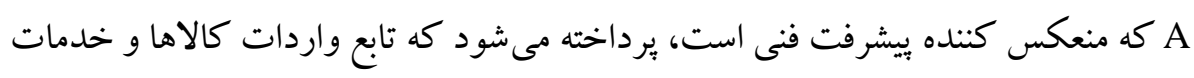
دلارى در نظر گرفته شده است:

$$
A=A_{0} \exp \left(\theta_{0}+\theta_{2} z z \$\right)
$$

$$
\begin{aligned}
& \text { نتيجه مى شود كه رشد پارامتر A يعنى Aبارت است از: } \\
& \dot{\mathrm{A}}=\Delta \log (\mathrm{A})=\theta_{2} \Delta(\mathrm{zz} \$) \\
& \text { اكنون اكر طرفين رابطه (9) را بر Lقسيم كنيم، رابطه زير حاصل مىشود: } \\
& \frac{\text { ynoil }}{\mathrm{L}}=\mathrm{A}\left(\frac{\mathrm{kno}}{\mathrm{L}}\right)^{\theta_{1}} \\
& \text { شكل لكاريتمى رابطه (•) (1) را در نظر مى گيريم: (1) } \\
& \log \left(\frac{\text { ynoil }}{\mathrm{L}}\right)=\log (\mathrm{A})+\theta_{1} \log \left(\frac{\mathrm{kno}}{\mathrm{L}}\right) \\
& \text { با جايخزينى A از رابطه (^)، رابطه زير به دست مى آيد: } \\
& \log \left(\frac{\text { ynoil }}{\mathrm{L}}\right)=\log \left(\mathrm{A}_{0}\right)+\theta_{0}+\theta_{2} \mathrm{zz} \$+\theta_{1} \log \left(\frac{\mathrm{kno}}{\mathrm{L}}\right) \\
& \operatorname{dlog}\left(\left(\frac{\text { ynoil }}{\mathrm{l}}\right)_{\mathrm{t}}\right)=0.32-0.23 \log \left(\left(\frac{\text { ynoil }_{\mathrm{l}}}{\mathrm{l}}\right)_{\mathrm{t}-1}\right)+0.06 \log \left(\mathrm{zz} \$_{\mathrm{t}-1}\right) \\
& +0.12 \mathrm{~d} \log \left(\mathrm{zz} \$_{\mathrm{t}}\right)+0.52 \mathrm{~d} \log \left(\left(\frac{\mathrm{kno}}{\mathrm{l}}\right)_{\mathrm{t}}\right)-0.1 \mathrm{~d}(\mathrm{~d} 67)
\end{aligned}
$$

gZ\$ واردات كالاها و خدمات را نشان مىدهد. همجنين با داشتن توليد غيرنفتى مى توان

$$
\begin{aligned}
& \text { از جمع اين رقم با ارزش افزوده نفت، كل توليد اقتصاد را به صورت زير استخراج كرد: } \\
& \mathrm{y}_{\mathrm{t}}=\text { ynoil }_{\mathrm{t}}+\text { yoil }_{\mathrm{t}}
\end{aligned}
$$


سرمايه گذارى بخش خصوصى به به دو زير مجموعه سرمايه گذارى بخش ساختمان و سرمايه گذارى ماشين آلات تفكيك شده است. در تابع سرمايه گذارى بخش سارئ ساختمان،

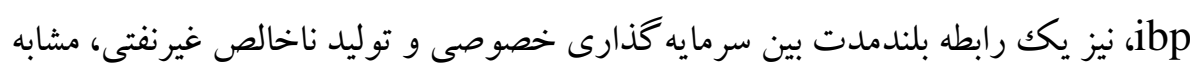
با تابع مصرف طراحى شده، در نظر گرفته شده است. علاوه بر شكل تصحيح خطا كه به ونه

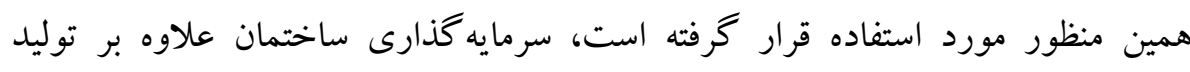
ناخالص غيرنفتى و وقفههاى آن به صورت تابعى از نرخ بهره حقيقى و نرخ تورم نيز

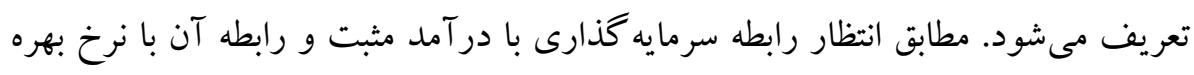

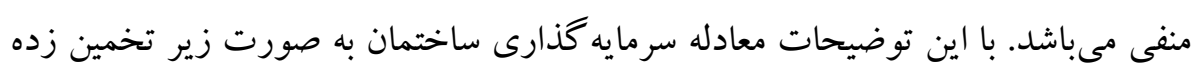
شده است: $\operatorname{dlog}\left(\mathrm{ibp}_{\mathrm{t}}\right)=5.68-0.8 \log \left(\mathrm{ibp}_{\mathrm{t}-1}\right)+0.9 \log \left(\left(\frac{\text { ynoil }}{1}\right)_{\mathrm{t}-1}\right)-0.8 \mathrm{~d} \log \left(\mathrm{p}_{\mathrm{t}}\right)-$ $0.6 \mathrm{~d}\left(\mathrm{rr}_{\mathrm{t}}\right)+0.2(\mathrm{~d} 86)+0.2(\mathrm{~d}(\mathrm{~d} 62))$

سرمايه گذارى در ماشين آلات، ieqp، توسط متغيرهاى توليد غيرنفتى، تورم و واردات كه به كمك شاخص قيمت دلارى usp حقيقى شده است، توضيح داده مىشود. معادله تصريح شده به صورت زير است: $\operatorname{dlog}\left(\right.$ ieqp $\left._{\mathrm{t}}\right)=-0.7-0.6 \log \left(\right.$ ieqp $\left._{\mathrm{t}-1}\right)+0.5 \log \left(\right.$ ynoil $\left._{\mathrm{t}-1}\right)-$ $1.4 \mathrm{~d} \log \left(\mathrm{p}_{\mathrm{t}}\right)+0.9 \mathrm{~d} \log \left(\left(\frac{\mathrm{zz} \$}{\mathrm{usp}}\right)_{\mathrm{t}}\right)-(\mathrm{d}(\mathrm{d} 65))+0.8(\mathrm{~d} 58)+$ $2.1 \operatorname{dog}\left(\right.$ ynoil $\left._{\mathrm{t}-1}\right)+$

$0.4 \mathrm{~d} \log \left(\left(\frac{\mathrm{zz} \$}{\mathrm{usp}}\right)_{\mathrm{t}-1}\right)$

همجيني مىتوان از جمع سرمايه گذارىهاى بخش ساختمان و ماشين آلات بر طبق

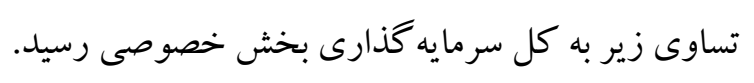

$\mathrm{ip}_{\mathrm{t}}=\mathrm{ibp}_{\mathrm{t}}+\mathrm{ieqp}_{\mathrm{t}}$

\section{F-r-r-r.}

در معادله قيمت از متغيرهاى نرخ ارز غيررسمى، نرخ بهره و نقدينگى استفاده شده

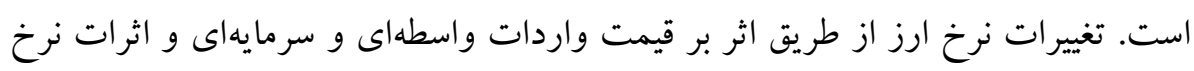

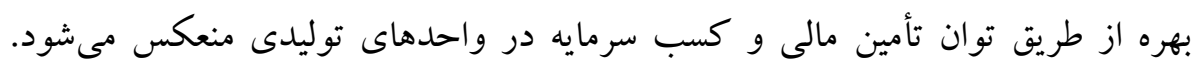


همجنين آهنك افزايش حجم نقدينكى از عوامل ديخرى است كه در تعيين نرخ تورم اثر

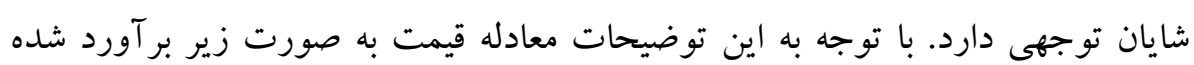
است:

$\operatorname{dlog}\left(\mathrm{p}_{\mathrm{t}}\right)=-1.3-0.18 \log \left(\mathrm{p}_{\mathrm{t}-1}\right)+0.11 \log \left(\right.$ uoex $\left._{\mathrm{t}-1}\right)+0.08 \log \left(\mathrm{mu}_{\mathrm{t}-1}\right)-$ $0.001 \mathrm{~d}\left(\left(\frac{1}{\text { opi1 }}\right)_{\mathrm{t}-1}\right)+0.14 \mathrm{~d} \log \left(\right.$ uoex $\left._{\mathrm{t}}\right)+0.6 \mathrm{~d} \log \left(\mathrm{mu}_{\mathrm{t}}\right)+0.3 \mathrm{~d} \log \left(\mathrm{ir}_{\mathrm{t}}\right)+$ $0.3 \mathrm{~d} \log \left(\mathrm{p}_{\mathrm{t}-1}\right)-0.1(\mathrm{~d}(\mathrm{~d} 68))$

شاخص قيمت نفت در داخل است كه بر اساس قيمت صادراتى و شاخص Opi1 ضمنى ارزش افزوده نفت ساخته شده است. Uoex نرخ ارز بازار سياه و همجنين در معادله فوق mu حجم نقدينكى است كه حضور آن در مدل در واقع بيان عرضه يول از ديدگاه منابع نقدينكى است. كه در بازار بول به اين گونه تعيين مىشود: $\mathrm{mu}_{\mathrm{t}}=\mathrm{nfa}_{\mathrm{t}}+\mathrm{dcg}_{\mathrm{t}}+\mathrm{dcp} \mathrm{t}_{\mathrm{t}}$

درحالى كه nfa خالص دارايى هاى خارجى سيستم بانكى، dcg اعتبارات داخلى بخش دولت، معادل خالص بدهى بخش دولتى به سيستم بانكى و dcp، اعتبارت داخلى بخش دانى دانى

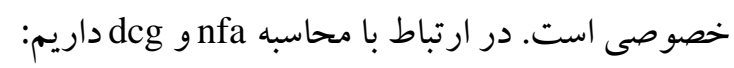
$\frac{100 * \mathrm{dcg}_{\mathrm{t}}}{\mathrm{p}_{\mathrm{t}}}=\frac{100 * \mathrm{dcg}_{\mathrm{t}-1}}{\mathrm{p}_{\mathrm{t}}}+\left(\mathrm{gc}_{\mathrm{t}}+\mathrm{ig}_{\mathrm{t}}-\mathrm{othr} 1_{\mathrm{t}}\right)-\frac{100 *\left(\operatorname{tiadj}_{\mathrm{t}}+\mathrm{it}_{\mathrm{t}}+\mathrm{oi}_{\mathrm{t}}\right)}{\mathrm{p}_{\mathrm{t}}}+\mathrm{u}_{-} \mathrm{dcg}$

كه dcg خالص بدهى دولت به سيستم بانكى است. در سمت راست تساوى، كسرى

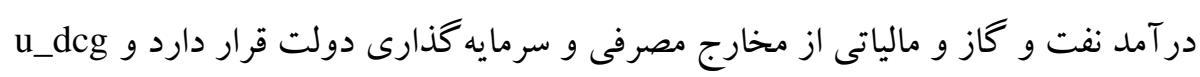
نيز متغيرى برونزاست كه دربر گيرنده ساير عوامل تغيير در خالص بلدهى دولت بـ به به سيستم

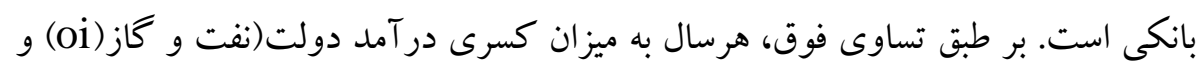

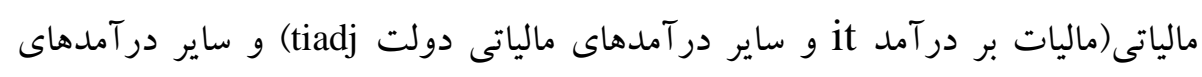
دولت othr1 از مخارج دولت بعلاوه u_dcg به بدهى خالص دوره قبل دولت به سيستم بانكى افزوده مىشود. در واقع dcg را مى توان سهم دولت از اعتبارات داخلى نيز دانست.

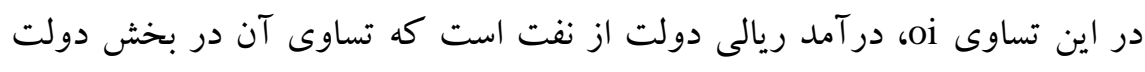
تشريح مىشود. $\frac{100 * \mathrm{nfa}_{\mathrm{t}}}{\mathrm{p}_{\mathrm{t}}}=\left(\frac{\mathrm{nfa}_{\mathrm{t}} \cdot \mathrm{oex}_{\mathrm{t}}}{10 * \mathrm{p}_{\mathrm{t}}}\right) * \mathrm{u} \_$nfa 
u_nfa

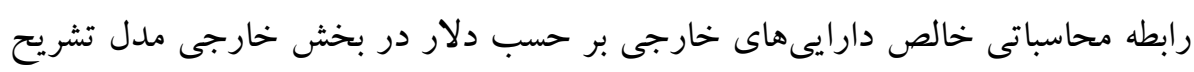
مى حكردد.

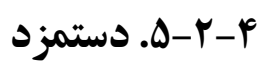

در منطق عدم تسويه در نهايت قدرت جانهزنى طرفين در تعيين قيمتها (در اينجا

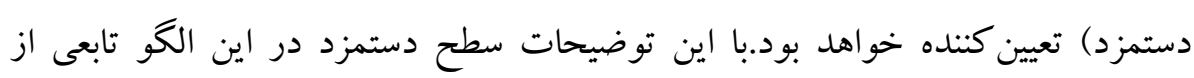
متغيرهاى توليد غيرنفتى سرانه، نرخ بيكارى و سطح عموم قيمتها بيان شده است.هميجنين

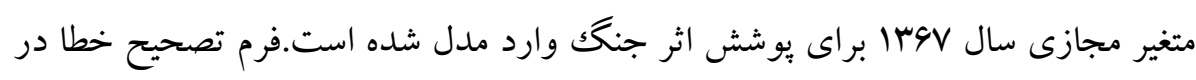

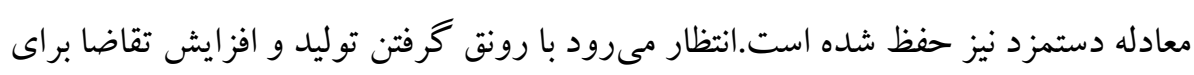
عوامل توليد سطح دستمزد افزايش يابد و با افزايش نرخ بيكارى و وفور نيروى كار سطح دستمزدها كاهش يابد.معادله دستمزد به شكل زير ارائه مى گرددد:

$\operatorname{dlog}\left(\mathrm{w}_{\mathrm{t}}\right)=$

$0.03-0.02 \log \left(\mathrm{w}_{\mathrm{t}-1}\right)+0.18 \log \left(\left(\frac{\text { ynoil }}{\mathrm{l}}\right)_{\mathrm{t}-1}\right)-0.25 \log \left(\mathrm{ur}_{\mathrm{t}-1}\right)-$

$0.51 \mathrm{~d} \log \left(\mathrm{ur}_{\mathrm{t}}\right)+0.25 \mathrm{dlog}\left(\mathrm{p}_{\mathrm{t}}\right)+012 \mathrm{~d} 67$

همجينين نرخ بيكارى بر اساس تعريف آن (نسبت تعداد جمعيت بيكار(·ل ساله و

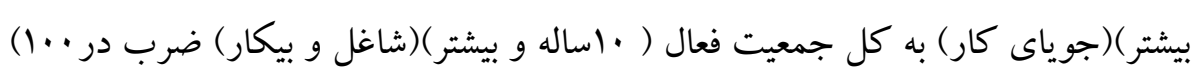
به صورت زير به دست مى آيد:

$\mathrm{ur}_{\mathrm{t}}=100\left(1-\left(\frac{\mathrm{l}_{\mathrm{t}}}{\text { laborf }_{\mathrm{t}}}\right)\right)$

كه laborft به ترتيب اشتغال و جمعيت فعال در سال t مىباشند.

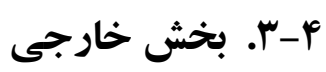

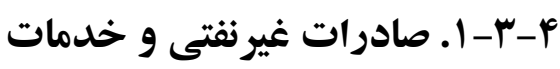

در اين مورد، با فرض اينكه اقتصاد ايران در زمينه صادرات غيرنفتى عاد، منطبق با شرايط

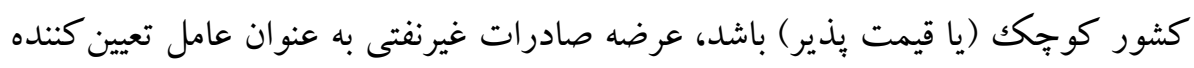

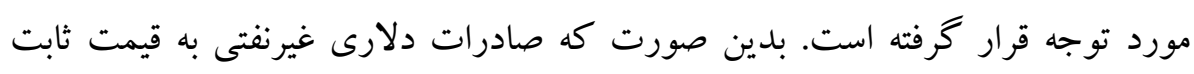

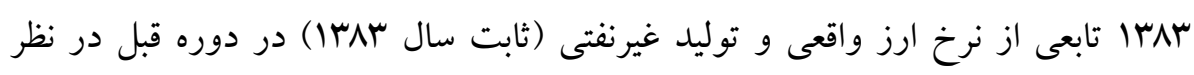


كر فته شده است. براى نمايش ارتباطات كو تاهمدت و بلندمدت معادله عرضه صادرات در قالب شكل تصحيح خطا طر احى شده است و براى انعكاس اثرات تحولات ارزى سالهاى

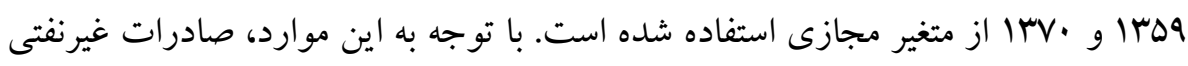

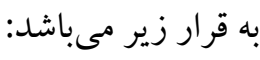
$\operatorname{dlog}\left(\mathrm{xx}_{\mathrm{t}}\right)=-8.2-0.09 \log \left(\mathrm{xx}_{\mathrm{t}-1}\right)+0.18\left(\log \left(\right.\right.$ uoex $\left.\left._{\mathrm{t}-1}\right)+\log \left(100\left(\frac{\text { usp }}{\mathrm{p}}\right)_{\mathrm{t}-1}\right)\right)+0.47 \log \left(\mathrm{ynoil}_{\mathrm{t}-1}\right)-$

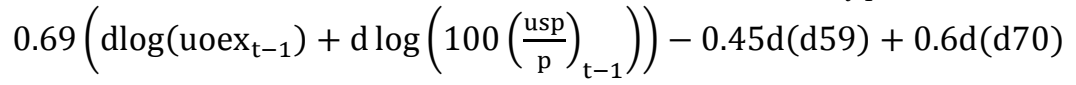
كه usp، شاخص قيمتى مصرف كننده براى كشور آمريكا و Uoex و نex نرخ ارز رسمى و غير رسمى مىباشند.

r r-r-r.r. واردات كالاها و خدمات

براى اجتناب از دركير شدن با دشوارىها و همهِجنين به منظور انعكاس تصويرى تقريبى از تأثير كنترلهاى ارزى به گونهاى كه تابع واردات طراحى شده انعطاف لازم براى كاربرد در شبيه سازى فضاهاى سياستى ديخر را نيز داشته باشد، سعى بر آن بوده است كه عملكرد كنترلهاى ارزى در قالب تعيين نرخ ارز وارداتى تبيين شود. بدين منظور فرض شده رك است

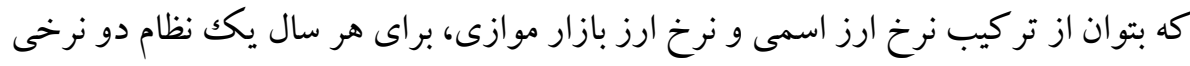

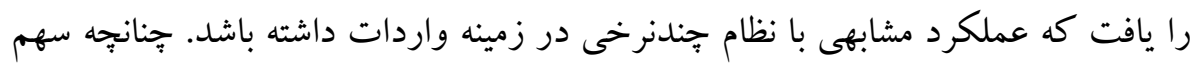
هندسى بازار موازى در تأمين ارز مورد نياز براى واردات را با متغير ع كه همواره در فاصله

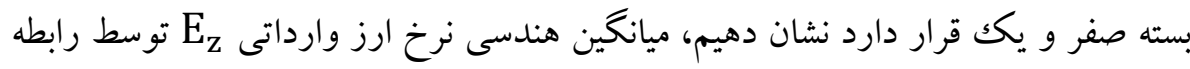
زير محاسبه مىشود:

$\mathrm{E}_{\mathrm{z}}=(\text { uoex })^{\varepsilon}(\text { oex })^{(1-\varepsilon)} ; 1 \geq \varepsilon \geq 0$

فرض مىشود كه ع يكك تابع كاهنده از خالص دارايىهاى خارجى سيستم بانكى بر حسب دلار ثابت سمץ| باشد. به بيان سادهتر، فرض مى كنيم، هر اندازه كه ذخاير خارجى

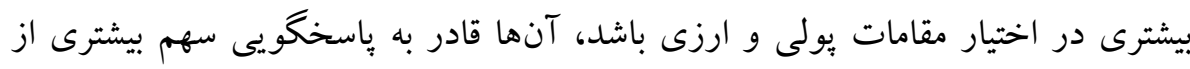
تقاضاى ارز براى واردات در نرخ رسمى خواهند بود و بالعكس، هنگًامى كه اين ذخاير كاهش بيدا مى كند، كاهش سهميههاى وارداتى سبب مى شود كه سهم بيشترى از تقاضاى ارز براى واردات، به بازار موازى ارز سرازير شود. بدين ترتيب مىتوان نوشت: 
$\varepsilon=\pi_{1}^{\prime}+\pi_{2}^{\prime}\left(\frac{\operatorname{NFA} \$(-1)}{\operatorname{USP}(-1)}\right) ; \pi_{1}^{\prime} \geq 0, \pi_{2}^{\prime} \leq 0$

در رابطه فوق، NFA\$ خالص دارايىهاى خارجى سيستم بانكى است. از طرفى، همان گونه كه در تابع صادرات غيرنفتى ملاحظه شد، نرخ ارز واقعى، بر مبناى نرخ ارز

$$
\mathrm{re}_{\mathrm{z}}=\frac{100 \mathrm{E}_{\mathrm{z}} \cdot \mathrm{USP}}{\mathrm{p}}
$$$$
\text { وارداتى E E E ابر است با: }
$$

با جايكزينى ع از رابطه (Yq) در (Yه) و با لكاريتم گيرى از طرفين رابطه، رابطه زير

$\pi_{2}^{\prime}\left(\frac{\operatorname{NFA} \$(-1)}{\operatorname{USP}(-1)}\right)(\log (\mathrm{UOEX})-\log (\mathrm{OEX}))+(\log (\mathrm{OEX})+$ حاصل مىشود: $\left.\log \left(\mathrm{re}_{\mathrm{z}}\right)=\pi_{1}^{\prime}(\log (\mathrm{UOEX})-\log (\mathrm{OEX}))+\log \left(\frac{100 . \mathrm{USP}}{\mathrm{p}}\right)\right)$ با جايخزين كردن $\log \left(\mathrm{re}_{z}\right)$ از رابطه ب ب در تابع واردات، همجنين اضافه كردن متغير توليد غيرنفتى به عنوان متغير توضيحى و متغيرهاى دامى براى سالهاى VY و شكل نهايى اين تابع به قرار زير به دست مى آيد: $\log \left(\left(\frac{\text { zz\$ }}{\text { usp }}\right)_{t}\right)=26.1-1.4\left(\log \left(\right.\right.$ uoex $\left._{t}\right)-\log \left(\right.$ oex $\left.\left._{t}\right)\right)+0.0008\left(\left(\frac{\text { nfa }}{\text { usp }}\right)_{t-1}\right) *\left(\log \left(\right.\right.$ uoex $\left._{t}\right)-\log \left(\right.$ oex $\left.\left._{t}\right)\right)-$ $1.5\left(\log \left(\right.\right.$ oex $\left.\left._{\mathrm{t}}\right)+\log \left(100 * \frac{\mathrm{usp}_{\mathrm{t}}}{\left(\mathrm{p}_{\mathrm{t}}\right)}\right)\right)+1.02 \mathrm{dlog}\left(\right.$ ynoil $\left._{\mathrm{t}-1}\right)+0.66(\mathrm{~d} 61)-0.31\left(\mathrm{~d} 72_{\mathrm{t}-1}\right)$

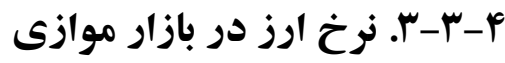

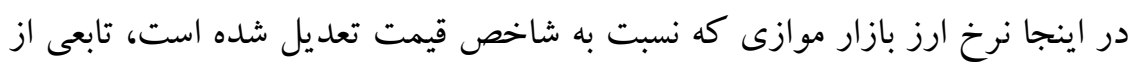

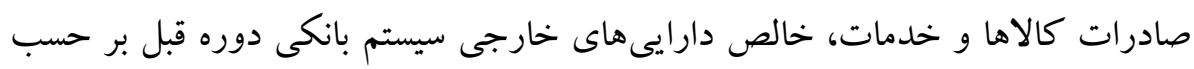

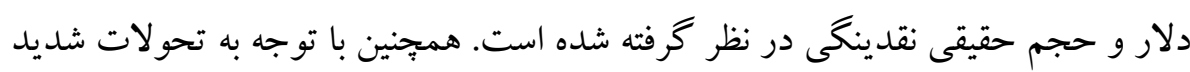

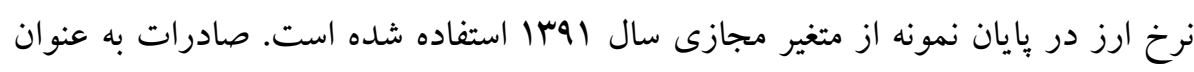

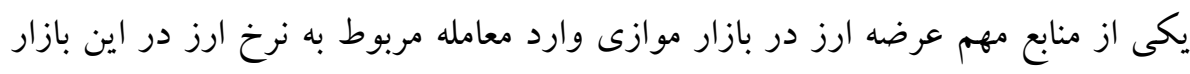

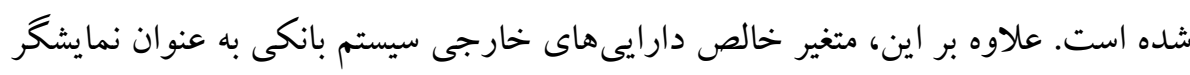

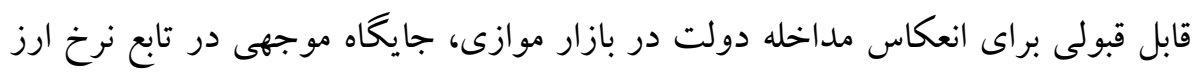

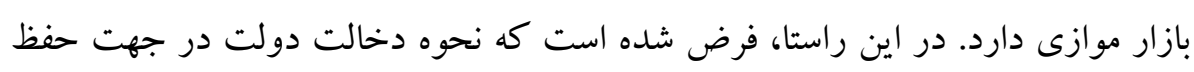

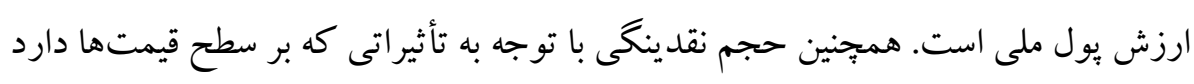


و به عنوان متغيرى كه مىتواند اثر تحولات بازار كالا را بر بازار ارز منعكس كند، منظور

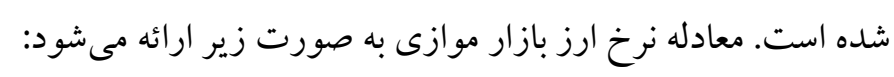
$\operatorname{dlog}\left(\left(\frac{100 . \text { uoex }}{\mathrm{p}}\right)_{\mathrm{t}}\right)=12.5-0.86 \log \left(\left(\frac{100 . \text { uoex }}{\mathrm{p}}\right)_{\mathrm{t}-1}\right)-0.3 \log \left(\mathrm{xx}_{\mathrm{t}-1}\right)-0.18 \log \left(\mathrm{nfa}_{\mathrm{t}-1}\right)-$ $0.13 d \log \left(x x \$_{t}\right)+0.48 d \log \left(\left(\frac{m u}{p}\right)_{t-1}\right)+0.26 d \log \left(\left(\frac{100 \cdot u \text { eex }}{p}\right)_{t-1}\right)+0.56 d(d 91)$

خالص دارايى هاى خارجى سيستم بانكى است كه به صورت زير محاسبه مىشود: $\mathrm{nfa} \$_{\mathrm{t}}=\mathrm{nfa} \$_{\mathrm{t}-1}+\operatorname{bop} \$_{\mathrm{t}}$ يعنى هر سال به ميزان تراز برداختها بر حسب دلار به خالص دارايىهاى خارجى بر

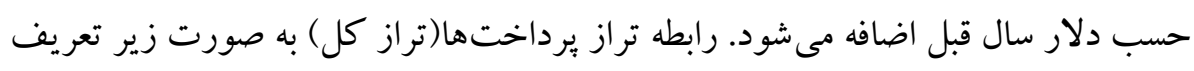
مىشود:

bop $\$_{t}=o x \$_{t}+x x \$_{t}+n s i \$_{t}-z z \$_{t}+$ bca $\$_{t}+u_{-} b o p \$$ به عبارتى موازنه كل يرداخت ها در هر سال برابر است با صادرات دلارى نفت به اضافه خالص صادرات غيرنفتى كالاها و خدمات، خالص در آمد بهرهاى و تراز سرمايه، منهاى واردات كالاها و خدمات و يكك جز باقيمانده U_bop\$ كه براى حفظ تساوى منظور شده است. همجنين صادرات دلارى نفت خود بر اساس رابطه زير به دست مى آيد: $\operatorname{dlog}(\mathrm{ox} \$ \mathrm{t})=\operatorname{dlog}\left(\mathrm{oxr}_{\mathrm{t}}\right)+\operatorname{dlog}\left(\mathrm{op} \$ 1_{\mathrm{t}}\right)$

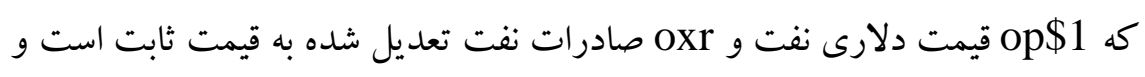
از تفاضل ارزش افزوده نفت و مصرف داخلى نفت به صورت زير محاسبه مىشود: $\operatorname{oxr}_{\mathrm{t}}=$ yoil $_{\mathrm{t}}-$ ocr $_{\mathrm{t}}$

همجِين مى توان به كمكك نرخ ارز اسمى و نسبت شاخص هاى قيمت داخلى و خارجى نرخ ارز حقيقى را به صورت زير محاسبه كرد: $\operatorname{ruoex}_{\mathrm{t}}=\operatorname{uoex}_{\mathrm{t}}\left(\frac{\mathrm{usp}_{\mathrm{t}}}{\mathrm{p}_{\mathrm{t}}}\right)$

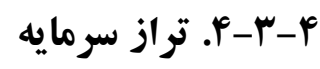

يكى از مشخصههاى اقتصاد ايران در اين مورد، اعمال كنترل بر نقل و انتقالات سرمايه است. هنگامى كه كسرى تراز تجارى وجود دارد موانع موجود بر سر راه وروود به كشور

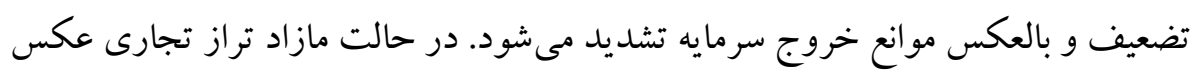


رفتار فوق اتخاذ خواهد شد. بنابراين انتظار مىرود به غير از متغيرهايى جون نرخ بهره خارجى و داخلى، وضعيت تراز تجارى نيز به واسطه عملكرد اين نوع خاص كنترل بر تراز سرمايه، از عوامل مؤثر بر تراز سرمايه باشد. بر مبناى مطالب فوق معادله تراز سرمايه دلارى به به

$$
\text { به قيمت ثابت به صورت زير طرح شده است: }
$$

$\mathrm{d}\left(\left(\frac{\text { bca\$ }}{\text { usp }}\right)_{\mathrm{t}}\right)=67.8-0.9\left(\left(\frac{\text { bca\$ }}{\text { usp }}\right)_{\mathrm{t}-1}\right)-0.44\left(\left(\mathrm{ox} \$_{\mathrm{t}-1}+\mathrm{xx} \$_{\mathrm{t}-1}+\mathrm{nsi}_{\mathrm{t}-1}-\mathrm{zz} \$_{\mathrm{t}-1}\right) / \mathrm{usp}_{\mathrm{t}-1}\right)+$

$11.8\left(\mathrm{rr}_{\mathrm{t}-1}-\mathrm{usrr}_{\mathrm{t}-1}\right)-0.62 \mathrm{~d}\left(\left(\mathrm{ox} \$_{\mathrm{t}}+\mathrm{xx} \$_{\mathrm{t}}+\mathrm{nsi} \$_{\mathrm{t}}-\mathrm{zz}_{\mathrm{t}}\right) / \mathrm{usp}_{\mathrm{t}}\right)-131.5 \mathrm{~d}(\mathrm{~d} 59)$

$-111.1 d 88+219.6 d(d 90)$

در اين رابطه usrr نرخ بهره حقيقى آمريكاو برونزا وnsi خالص در آمد بهرهاى مىباشد.

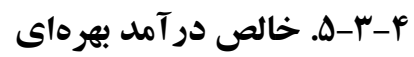

خالص دارايىهاى خارجى بخش خصوصى و بخش دولتهى، منشأ كسب اين قبيل

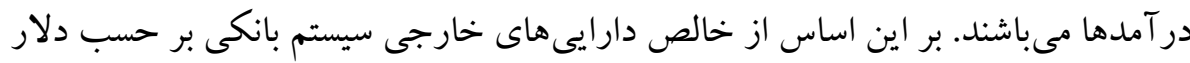
به عنوان متغير توضيحى استفاده شده است. همجنين تلاش شده در سالهايى كه وقايع

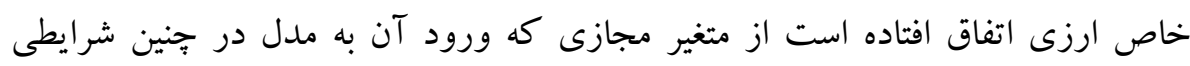
توجيه يذير است، استفاده شود. فرض اين است كه به بخشى از خالص دارايىهاى خارجى

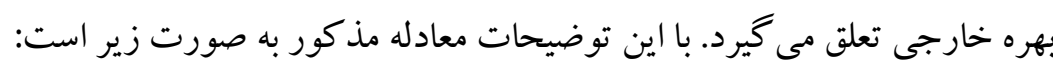
$\mathrm{nsi} \$_{\mathrm{t}}=81.74+0.43 \mathrm{nsi} \$_{\mathrm{t}-1}+0.67\left(\left(\frac{\text { nfas.usrr }}{100}\right)_{\mathrm{t}-1}\right)-0.61\left(\left(\frac{\text { nfas.usrr }}{100}\right)_{\mathrm{t}-2}\right)+0.26\left(\left(\frac{\text { nfas.usrr }}{100}\right)_{\mathrm{t}-3}\right)$ $-518.57(\mathrm{~d} 72)+412.1 \mathrm{~d}\left(\mathrm{~d} 80_{\mathrm{t}-1}\right)+1750.6 \mathrm{~d}(\mathrm{~d} 91)$

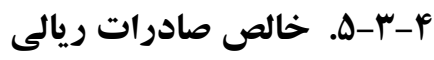

$$
\begin{aligned}
& \text { از تساوى زير استخراج مىشود: } \\
& \mathrm{nx}_{\mathrm{t}}=\operatorname{oxr}_{\mathrm{t}}+\left(\frac{\text { uoex }_{\mathrm{t}} *\left(\mathrm{xx} \$_{\mathrm{t}}+\mathrm{nsi} \phi_{\mathrm{t}}-\mathrm{zz} \$_{\mathrm{t}}\right)}{10 * \mathrm{p}}\right)+\mathrm{u} \_\mathrm{nx} \\
& \text { متغيرى برونزا است كه طرفين رابطه را برابر مى كند. U_nx }
\end{aligned}
$$

\section{P}

\section{F}

در اين معادله كه به فرم سرانه و تصحيح خطا تعريف شدوه دوه است، مخارج مصرفى دولت به كل درآمدهاى دولت و سطح عمومى قيمتها مرتبط شده است. تصريح اين معادله به صورت زير خواهد بود: 
$\operatorname{dlog}\left(\left(\frac{\mathrm{gc}}{\mathrm{pop}}\right)_{\mathrm{t}}\right)=0.12-0.09 \log \left(\left(\frac{\mathrm{gc}}{\mathrm{pop}}\right)_{\mathrm{t}-1}\right)+0.1 \mathrm{~d} \log \left(\left(\frac{\mathrm{tr}}{\mathrm{p} * \mathrm{pop}}\right)_{\mathrm{t}-1}\right)-$

$0.2 \mathrm{~d} \log \left(\mathrm{p}_{\mathrm{t}}\right)-0.2(\mathrm{~d}(\mathrm{~d} 65))-0.06(\mathrm{~d} 89)+0.1 \mathrm{~d}(\mathrm{~d} 72)$

$$
\text { rr }
$$

$\frac{100 * \operatorname{tr}_{\mathrm{t}}}{\mathrm{p}_{\mathrm{t}}}=\frac{100 *\left(\text { tiadj }_{\mathrm{t}}+\mathrm{it}_{\mathrm{t}}+\mathrm{oi}_{\mathrm{t}}\right)}{\mathrm{p}_{\mathrm{t}}}+$ othr $1_{\mathrm{t}}$

كه it ماليات بر درآمد، tiadj، ساير درآمدهاى مالياتى، oi درآمد ريالى نفت و

$$
\text { othr1 }
$$

\section{政}

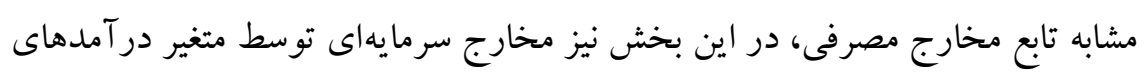
دولت توضيح داده مىشود و جسبند گىهاى مخارج در فرم تصحيح خطا قابل مشاهده

$$
\text { است كه نتايج اين معادله به صورت زير مىباشد: }
$$

$\operatorname{dlog}\left(\left(\frac{\mathrm{ig}}{\text { pop }}\right)_{\mathrm{t}}\right)=-1.59-0.47 \log \left(\left(\frac{\mathrm{ig}}{\mathrm{pop}}\right)_{\mathrm{t}-1}\right)+0.44 \operatorname{dlog}\left(\left(\frac{\operatorname{tr}}{\mathrm{p} * \text { pop }}\right)_{\mathrm{t}}\right)+$

$0.14 \log \left(\left(\frac{\operatorname{tr}}{p * \text { pop }}\right)_{t-1}\right)-0.87 \mathrm{~d} \log \left(\mathrm{p}_{\mathrm{t}}\right)-0.6(\mathrm{~d} 58)-0.4(\mathrm{~d}(\mathrm{~d} 68))$

\section{(}

مصرف سرانه نفت در داخل كه از تجزيه ارزش افزوده حاصل شده احل است تابعى از توليد سرانه غيرنفتى، نسبت شاخص قيمت نفت در داخل به سطح عمومى قيمتها و و واردات حقيقى در نظر گرفته شده است كه اين معادله به صورت زير ارائه مى گرددد: $\operatorname{dlog}\left(\left(\frac{\text { ocr1 }}{\text { ynoil }}\right)_{t}\right)=-1.98-0.9 \log \left(\left(\frac{\text { ocr } 1}{\text { ynoil }}\right)_{t-1}\right)-0.09 \log \left(\left(\frac{\text { zz } \$}{\text { usp }}\right)_{t-1}\right)+0.15 \operatorname{dlog}\left(\left(\frac{\text { ocr } 1}{\text { ynoil }}\right)_{t-1}\right)-$ $0.2 \mathrm{~d} \log \left(\left(\frac{\mathrm{zz} \$}{\mathrm{usp}}\right)_{\mathrm{t}}\right)-0.16 \mathrm{~d} \log \left(\left(\frac{\mathrm{zzz} \mathrm{s}}{\mathrm{usp}}\right)_{\mathrm{t}-1}\right)-0.02 \mathrm{~d}\left(\left(\frac{\mathrm{opi} 1}{\mathrm{p}}\right)_{\mathrm{t}}\right)-0.6(\mathrm{~d}(\mathrm{~d} 59))+0.6(\mathrm{~d}(\mathrm{~d} 61))-0.97(\mathrm{~d} 67)$

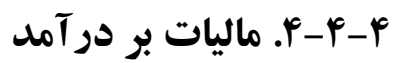

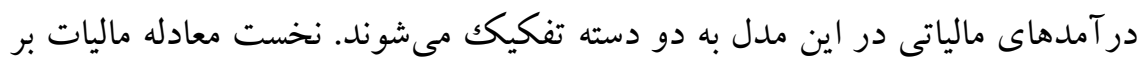
درآمد و پِ از آن ساير در آمدهاى مالياتى بر آورد شدهاند. همانطور كه انتظار مىرود

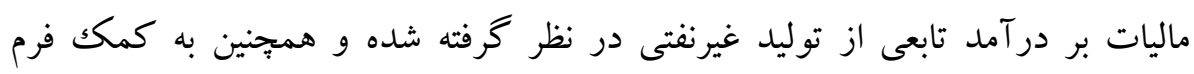


تصحيح خطا به مقدار گذشته متغير تابع مربوط كشته است. نتايج اين تخمين به صورت زير است: $\operatorname{dlog}\left(\left(\frac{i t}{p}\right) t\right)=-11.47-0.6 \log \left(\left(\frac{i t}{p}\right)_{t-1}\right)+1.05 \log \left(\right.$ ynoil $\left._{t-1}\right)+$

$1.39 \mathrm{~d} \log \left(\right.$ ynoil $\left._{\mathrm{t}}\right)-0.16 \mathrm{~d} 62-0.33 \mathrm{~d} 80_{\mathrm{t}-1}$

(FY)

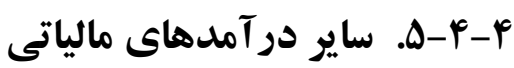

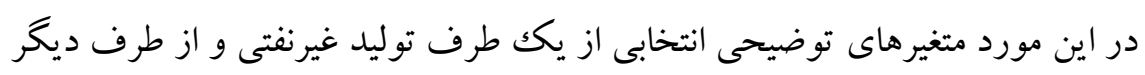

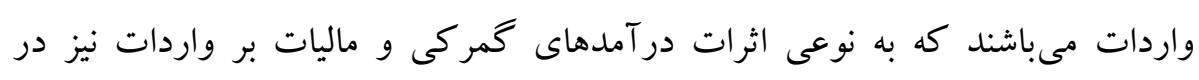

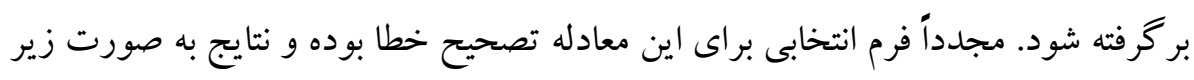
است: $\operatorname{dlog}\left(\left(\frac{\text { tiadj }}{p}\right) t\right)=-2.88-0.3 \log \left(\left(\frac{\text { tiadj }}{p}\right)_{t-1}\right)+0.34 \log \left(\right.$ ynoil $\left._{t-1}\right)+$ $1.24 \mathrm{~d} \log \left(\right.$ ynoil $\left._{\mathrm{t}}\right)+0.36 \mathrm{dlog}\left(\left(\frac{\mathrm{zz} \$}{\mathrm{usp}}\right)_{\mathrm{t}-1}\right)$

\section{F-F-F}

سرمايه گذارى دولت در بخش نفت و كاز تابعى از توليد نفت به صورت كرفته شده است: $\operatorname{dlog}\left(\operatorname{ogsi}_{\mathrm{t}}\right)=0.53-0.57 \log \left(\operatorname{ogsi}_{\mathrm{t}-1}\right)-0.68(\mathrm{~d} 64)+0.92(\mathrm{~d} 75)-$

$1.18(\mathrm{~d}(\mathrm{~d} 90))+0.62 \mathrm{~d} \log \left(\right.$ yoil $\left._{\mathrm{t}}\right)+0.4 \log \left(\right.$ yoil $\left._{\mathrm{t}-1}\right)$

تساوى آخر از بخش دولت مربوط به درآمد ريالى دولت از نفت است كه به صورت

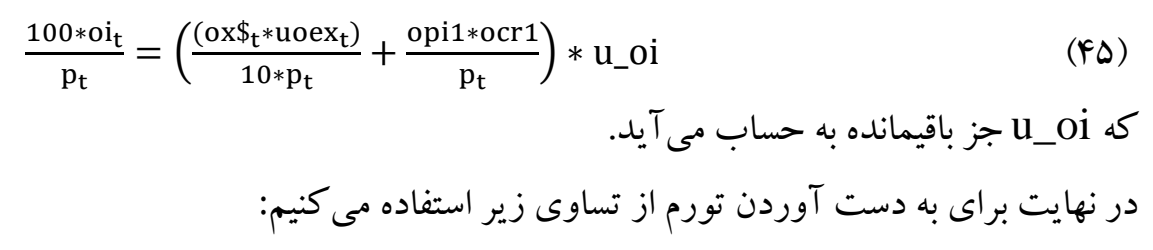

$\mathrm{pi}_{\mathrm{t}}=100 * \operatorname{dlog}\left(\mathrm{p}_{\mathrm{t}}\right)$

لازم به ذكر است، متغيرهاى درونزا و برونزاى معادلات فوق در جداول (1) و (Y) 


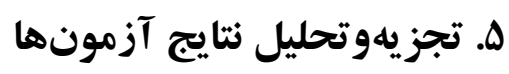

ه- ا. - هادههاى تحقيق

كليه دادهاى سرى زمانى مورد استفاده در اين تحقيق در فاصله سالهاى

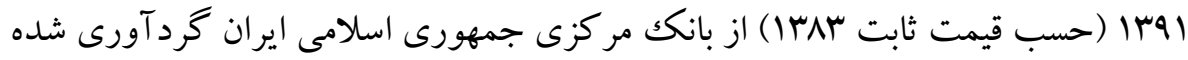

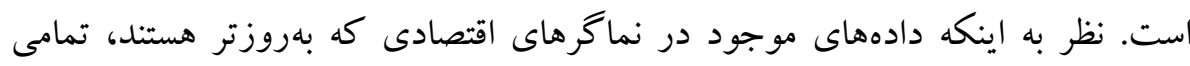

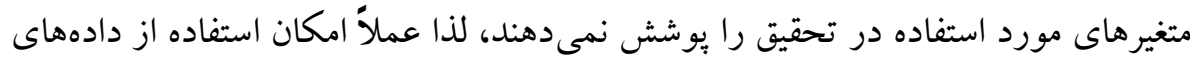

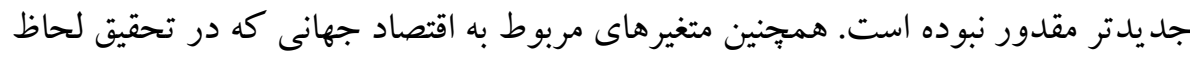

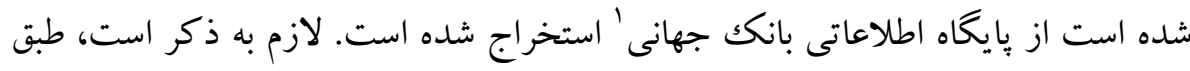

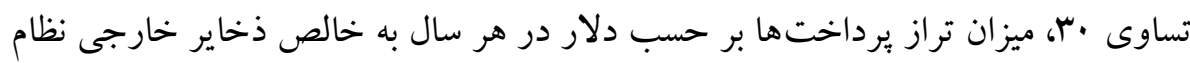

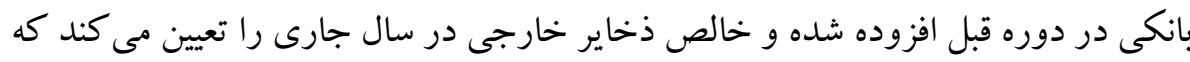

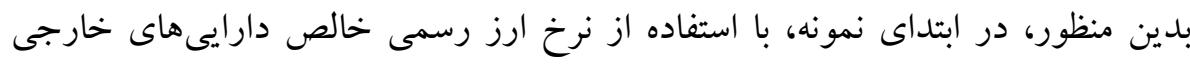

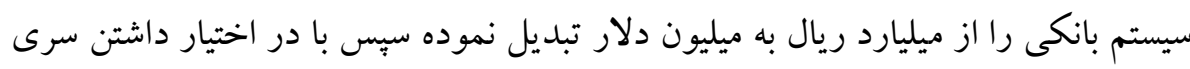

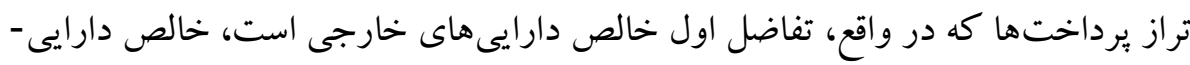

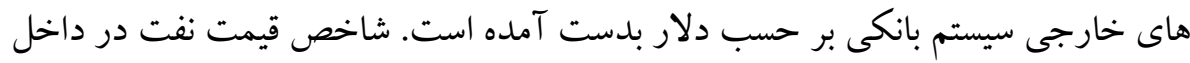

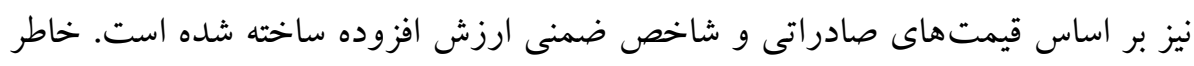

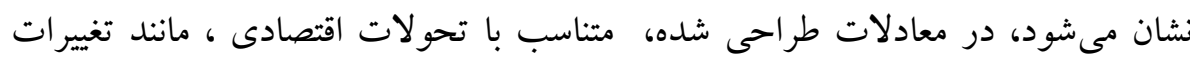
شديد نرخ ارز در سال الجها، از متغير مجازى استفاده شده است.

\section{ه-r. بر آورد مدل و قدرت توضيحدهندكى مدل}

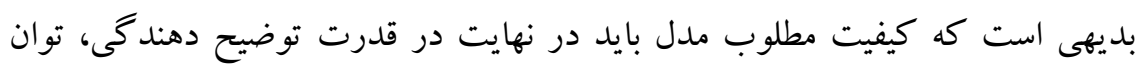

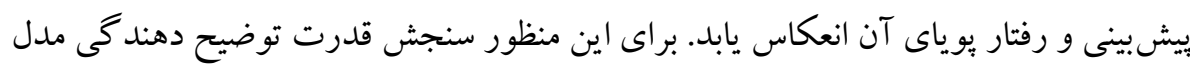

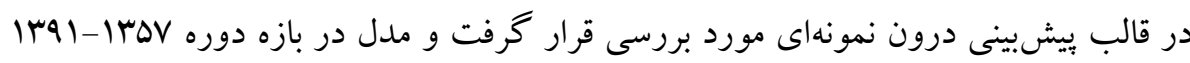

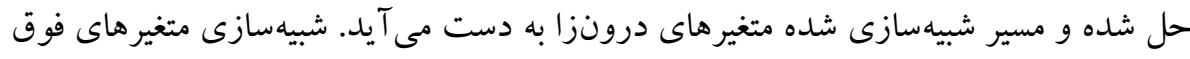

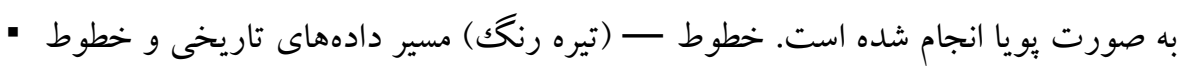

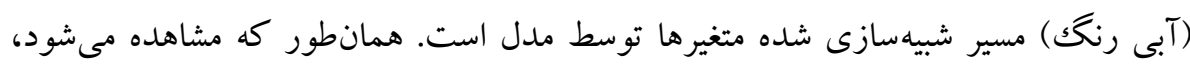

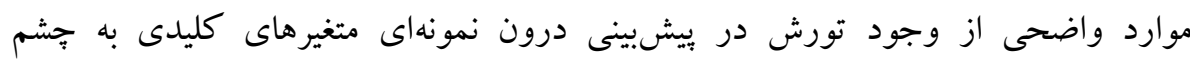


نمى خورد و مدل تو انسته است واقعيات را به ميزان رضايتبخشى به درستى ترسيم نمايد. در

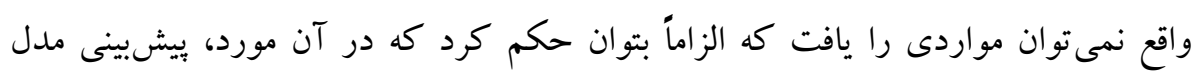

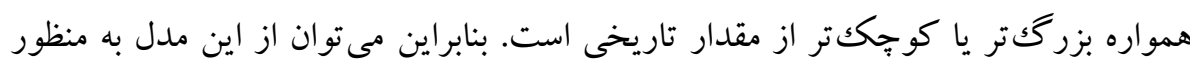
سناريوبردازى و تحليل سياستى استفاده كرد.
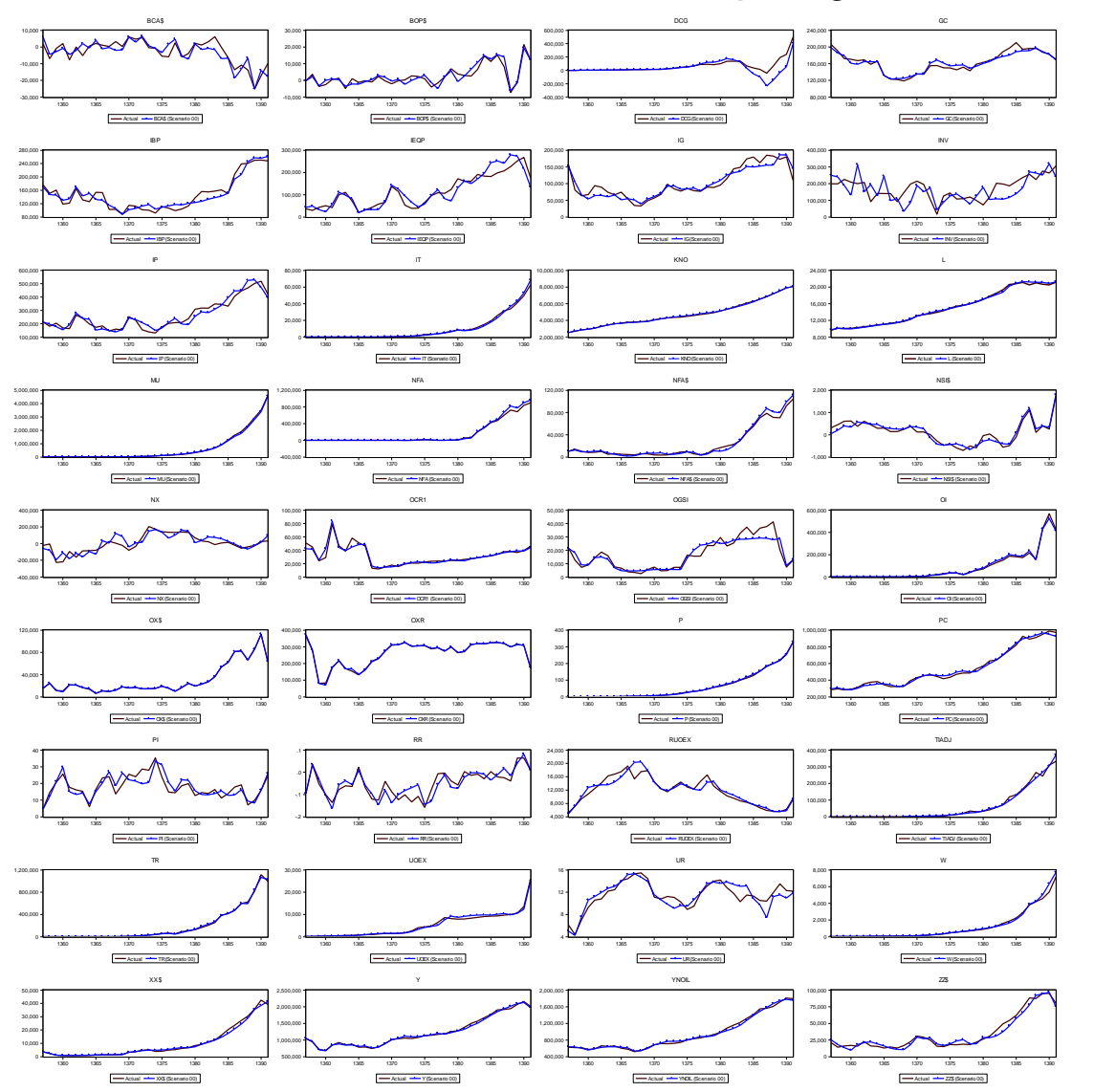

نمودار ا. يِيشينى درون نمونهاى مدل

مأخذ: يافتههاى تحقيق

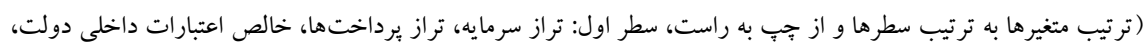

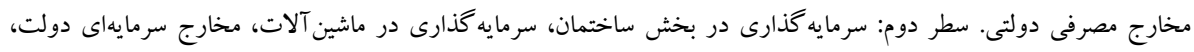

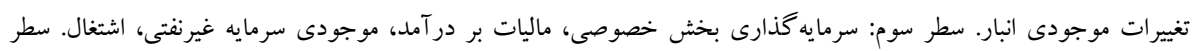

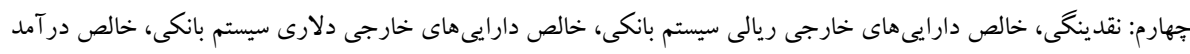

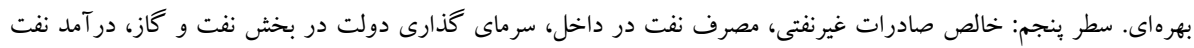

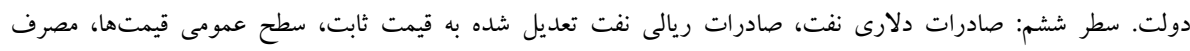

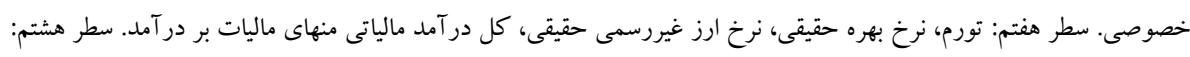

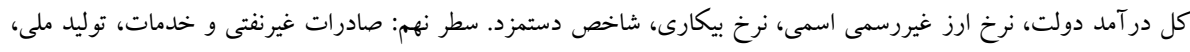


ه-" آ. تجزيه و تحليل نتايج تحقيق

با توجه به هدف اصلى تحقيق حاضر در اين بخش توضيحاتى در مورد نحوه ورود

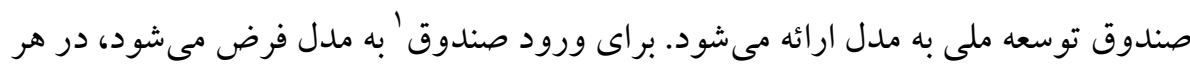

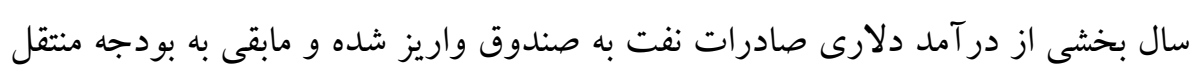

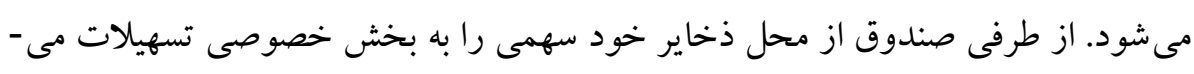

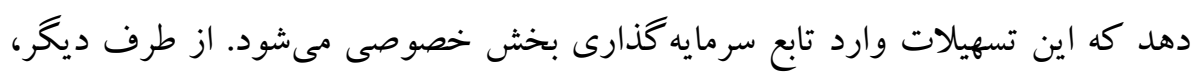

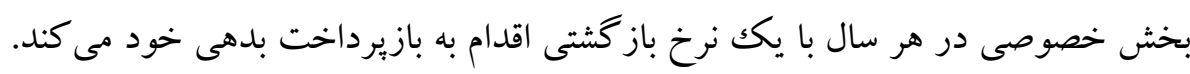

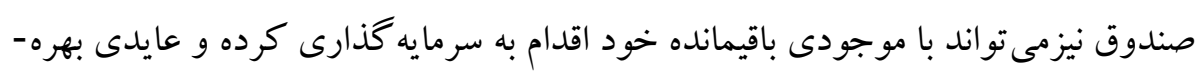
اى به دست آورد.

طراحى صندوق نيز به دو نوع صورت گرفته است. حالتى كه صندوق سهم ثابتى از

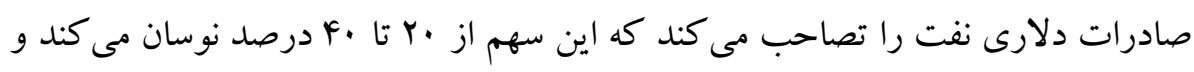

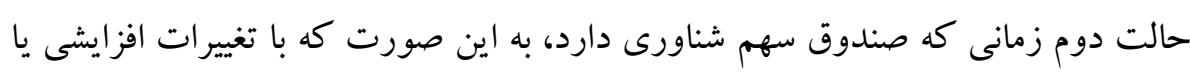
كاهش عايدىهاى دولت سهمى كه نصيب صندوق مى شود نيز متغير است. بايستى خاطر نشان كرد كه منظور از شناور كردن سهم صندوق توسعه ملى از در آمدهاى نفتى به معناى اتخاذ سياست ضدسيكلى در تخصيص درآمدهاى نفتى است. به عبارت ديخر در اين حالت توصيه مىشود زمانى كه اقتصاد در وضعيت ركود قرار دارد، سهم صندوق از در آمدهاى نفتى كاهش و زمانى كه اقتصاد در وضعيت رونق قرار دارد، سهم صندوق از در آمدهاى نفتى افزايش يابد. با عنايت به اين توضيحات در ادامه به بررسى سناريوهاى محتمل تحقيق در خصوص يته

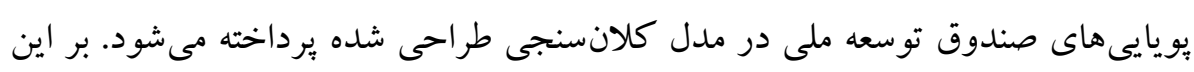
اساس سه سناريو به صورت سناريو وجود و عدم وجود صندوق توسعه ملى (يا سناريو

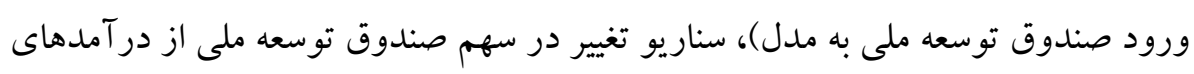
نفتى و سناريوى واكنش صندوق به شوكى موقت و دائمى نفت طراحى شده است كه در ادامه به بررسى و تحليل هر يكك از آنها برداخته مئى وشود. 
ه-r-1- ا. سناريو وجود و عدم وجود صندوق (ورود صندوق توسعه ملى به مدل)

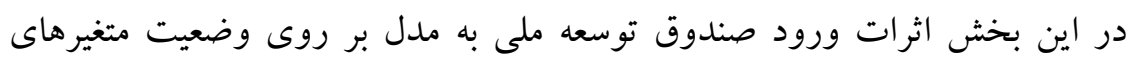

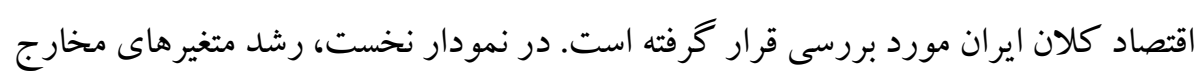

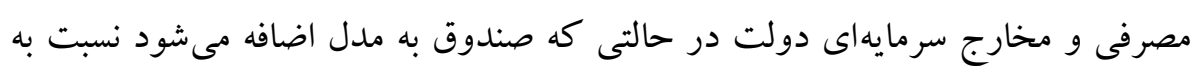
زمانى كه صندوق نباشد، به ترتيب با خطوط - ـ و قابل مشاهده است. در نمودار دوم

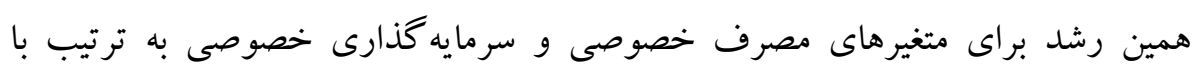

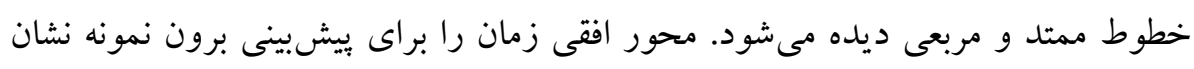

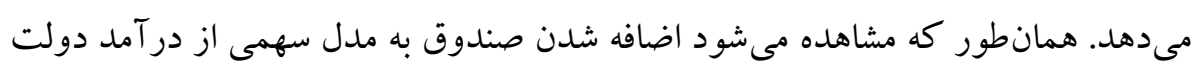

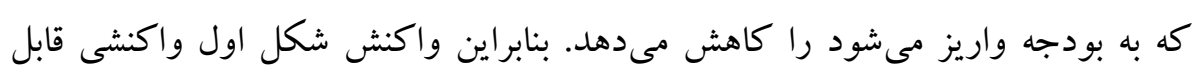
انتظار است. زيرا توان خرج كردن دولت با اين اقدام كاهش مى يابد. در شكل دوم دوم مشاهده

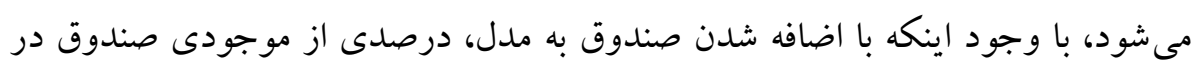

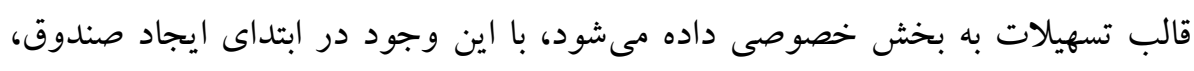

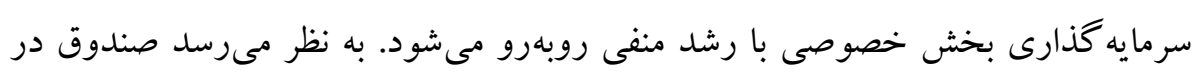

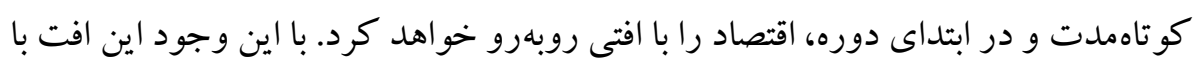

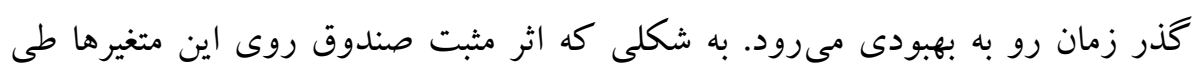

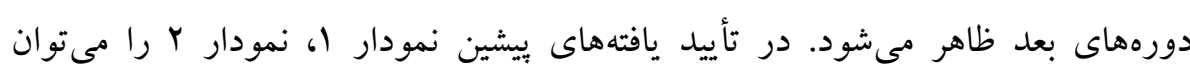
مشاهده كرد. در اين نمودار متغيرهاى مورد بررسى به ترتيب سطر اول از سمت جِّب توليد

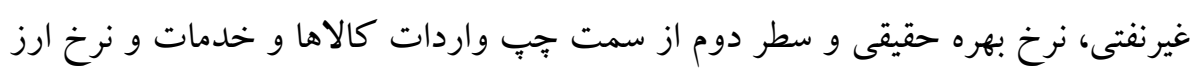

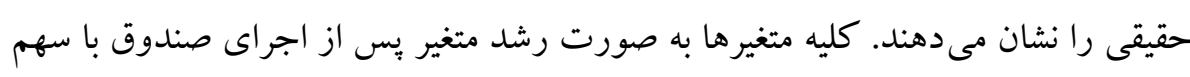
• r درصد نسبت به زمانى كه صندوق در مدل وجود ندارد، در نظر كرفته شدهاند. 


\section{طر احى يك مدل كلانسنجى بويا با لحاظ يويايىهاى صندوق توسعه ملى براى اقتصاد ايران}
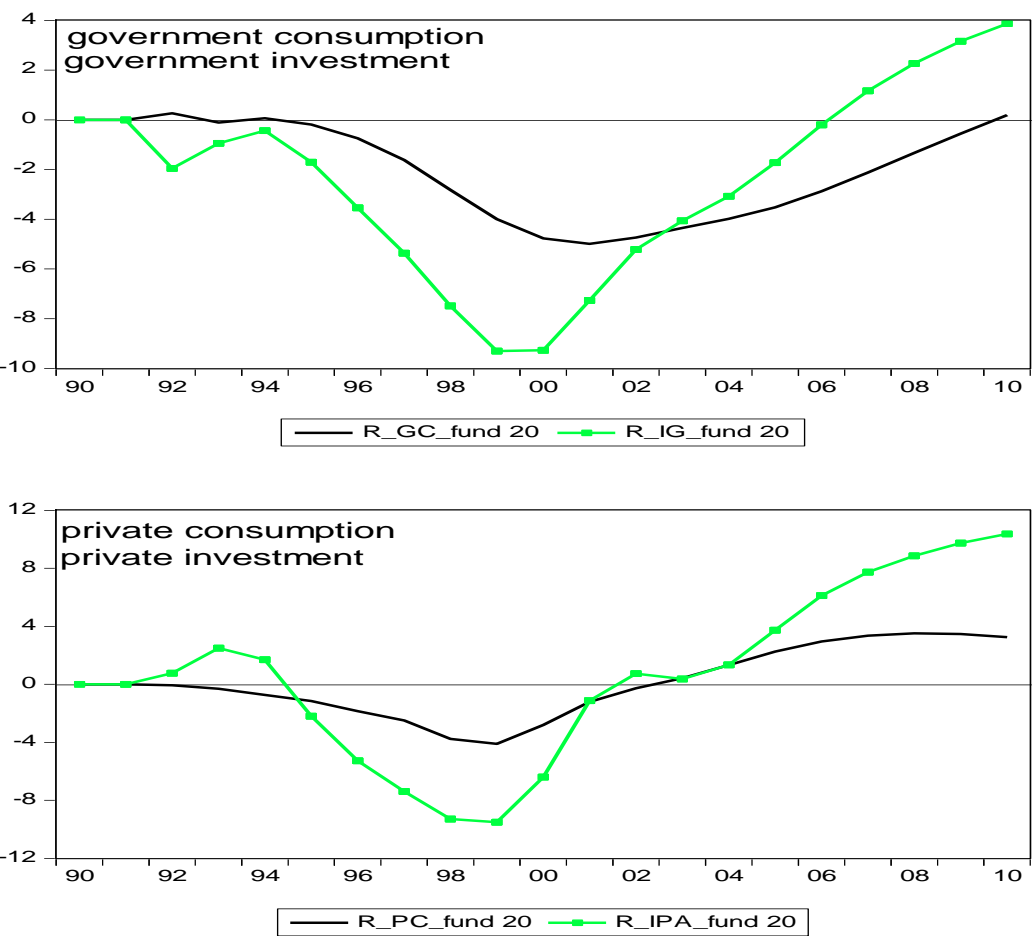

نمودار r. رشد متغير هاى كلان در حالت وجود صندوق نسبت به وضعيت اقتصاد بدون صندوق

$$
\text { بر اساس بيشبينى برون نمونه }
$$

مأخذ: يافته هاى تحقيق

بويايىهاى تابع عكس العمل متغير توليد غيرنفتى نسبت به واريز ·. د درصد از درآمدهاى نفتى به صندوق توسعه ملى را مىتوان جنين تفسير نمود كه، طى سالهاى

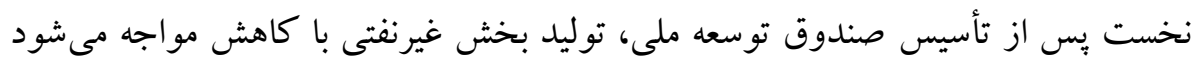

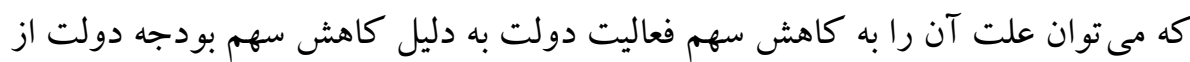
درآمدهاى نفتى نسبت داد كه منجر به كاهش توليد بخش غيرنفتى در اقتصاد شده است.

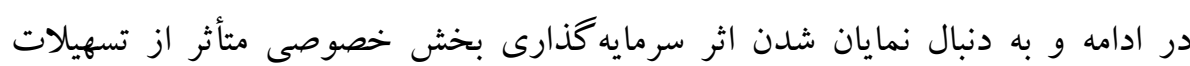
اعطايى از سوى صندوق توسعه ملى، مى توان شاهد افزايش توليد بخش غيرنفتى در اقتصاد 

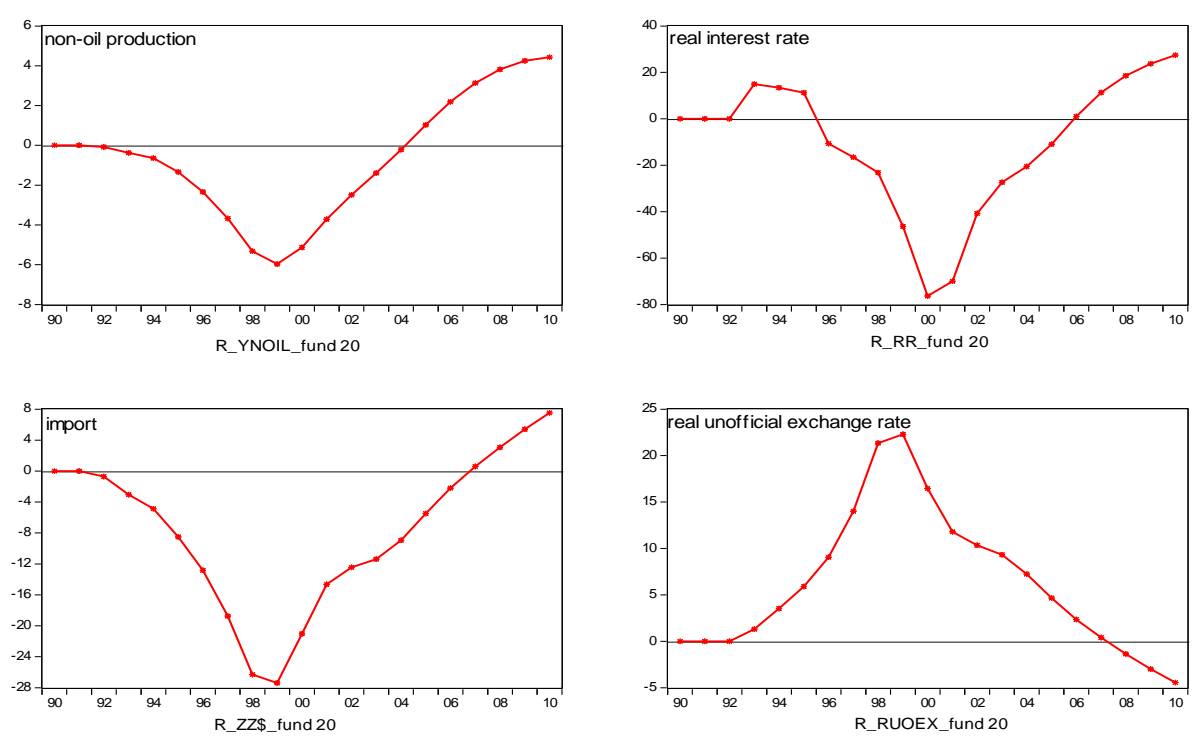

نمودار r. درصد رشد متغيرهاى اقتصاد كلان در حالت با صندوق (سهم بيست درصد) و اقتصاد بدون صندوق

مأخذ: يافته هاى تحقيق

ه-r-r-r- سناريو تغيير در سهم صندوق از درآمدهاى نفتى

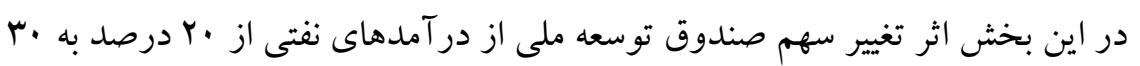

درصد و ·F درصد به تصوير كشيده شده است. خطوط - " •و • به ترتيب رشد متغيرها

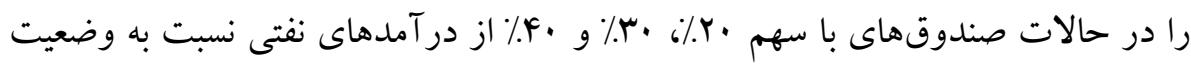
بدون صندوق پِايه نشان مى دهند. متغيرهاى سطر اول از سمت جٍِ به ترتيب توليد غيرنفتى و نرخ ارز غيررسمى و سطر دوم از سمت جِ به ترتيب تورم و خالص اعتبارات بخش دولتى مىباشند. همانطور كه مشاهده مىشود با افزايش سهم صندوق، افت اوليه توليد و در كنار آن در بلندمدت، افزايش توليد هر دو تشديد مىشود. تشديد اثرات با افزايش سهم صندوق، در هر سه متغير ديخر نيز به جشم مى خورد. مشاهده مىشود كه اثرات توليدى و تورمى صندوق برخلاف جهت هم حركت مى كنند. 


\section{طر احى يك مدل كلانسنجى يويا با لحاظ يويايىهاى صندوق توسعه ملى براى اقتصاد ايران}
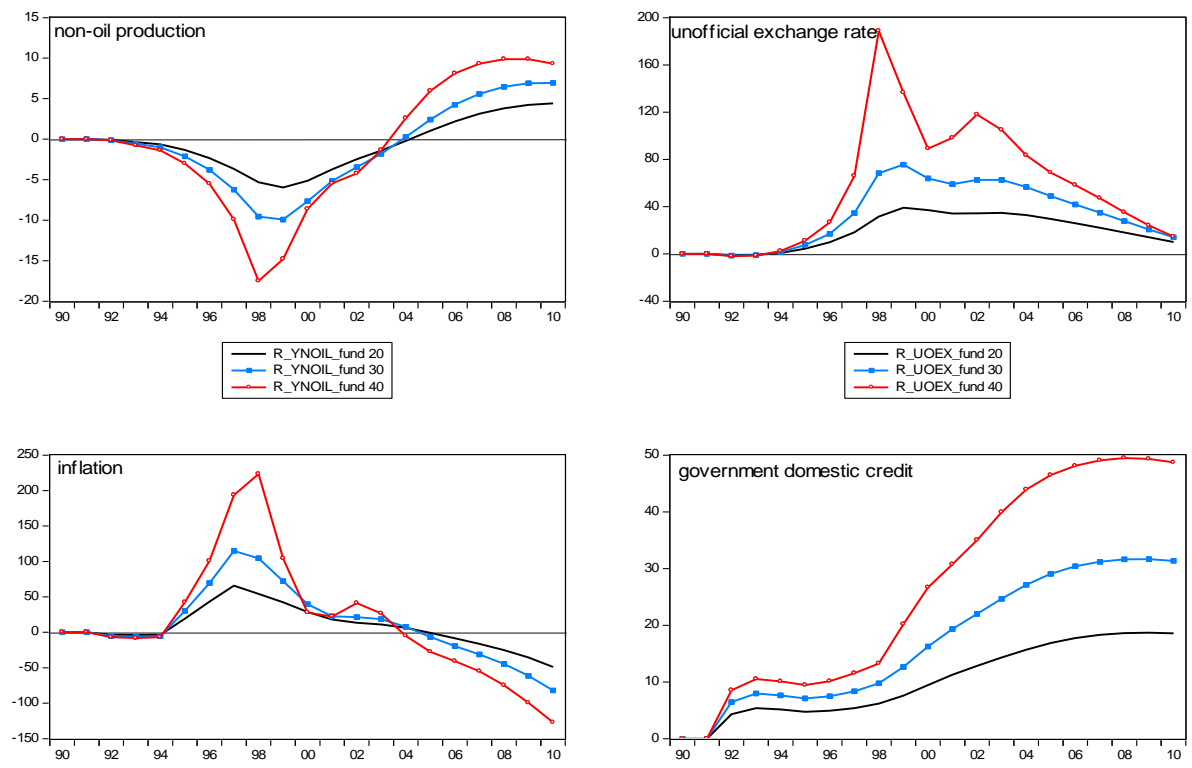

\begin{tabular}{l} 
RPPl fund 20 \\
\#-RPI fund 30 \\
\hline R_Pl_fund 40 \\
\hline
\end{tabular}

\begin{tabular}{l} 
E-R_DCG_fund 20 \\
三-R_DCG fund 30 \\
二-R_DCG_fund 40 \\
\hline
\end{tabular}

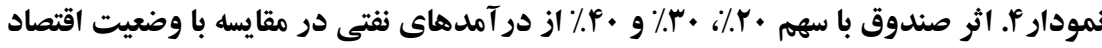

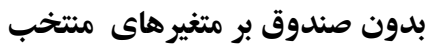

مأخذ: يافته هاى تحقيق

نمودار شماره F، موجودى صندوق را در سه سناريوى سهم ·r، ·r و ·F درصدى براى صندوق نشان مىدهد. مطابق انتظار، با افزايش سهم صندوق از درآمدهاى دلارى نفت، موجودى صندوق نيز در طول زمان افزايش مىيابد.

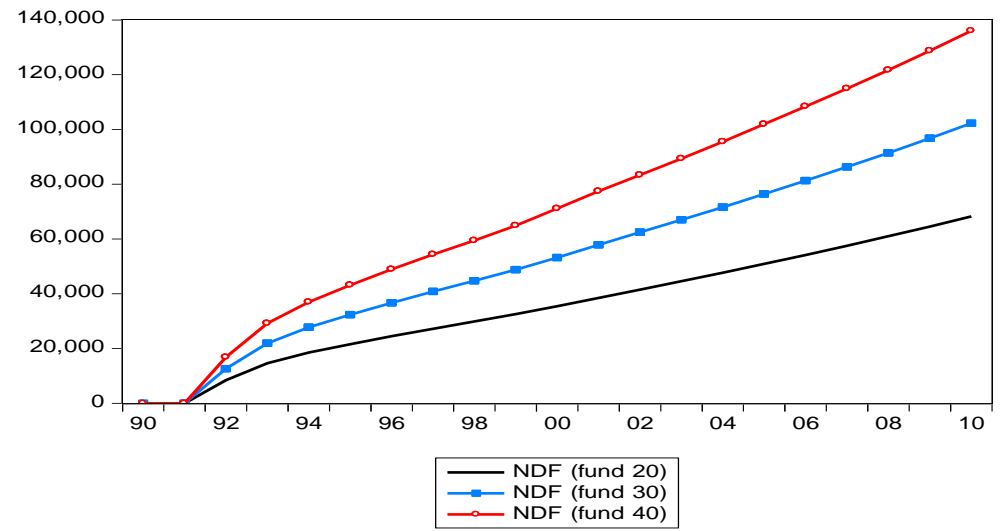

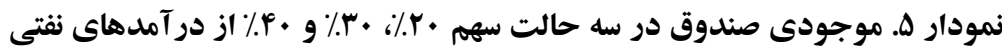
مأخذ: يافته هاى تحقيق 
در ادامه براى قوت بخشيدن به تحليل و جامعيت بيشتر براى در نظر گرفتن احتمالاتى

كه ممكن است در فضاى سياست گذارى رخ دهند، با تغيير تساوىهاى مدل، دو حالت جديد طراحى مىشود. حالت دوم مربوط به زمانى است كه در كنار تساوى نرخ ارز بازار سياه و رسمى يا به اصطلاح سيستم تكك نرخى (حالت اول)، تابع عكس العملى براى مخارج

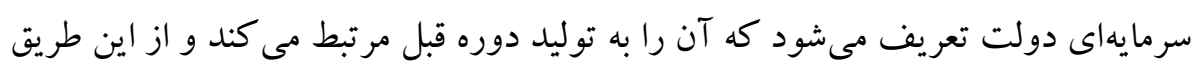
ماهيتى ضدسيكلى به بودجه داده مىشود. حالت سوم زمانى است كه امكان تغيير نرخ ارز رسمى داده نمىشود و حالت نرخ ارز ثابت ايجاد مىشود. تساوىهاى مربوط به سيستم

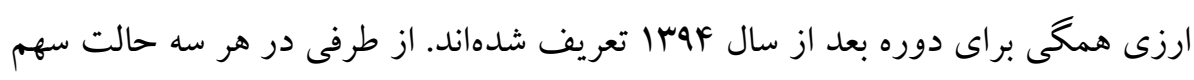

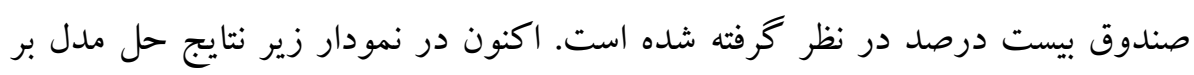
روى متغيرهاى منتخب بر اساس اين سه حالت ارائه مى گردد.

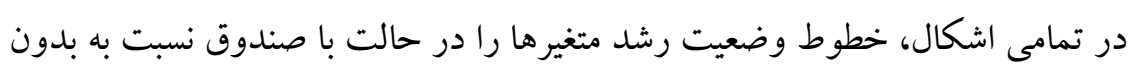
صندوق نشان مىدهند. خطوط - حالت اول، خطوط " حالت دوم و خطوط • حالت سوم مىباشند. همانطور كه مشاهده مىشود، اعمال محدوديت روى بودجه سرمايهاى

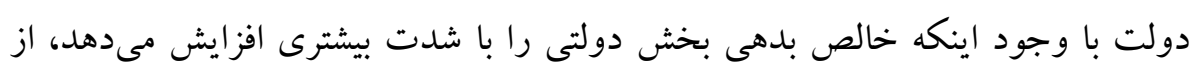

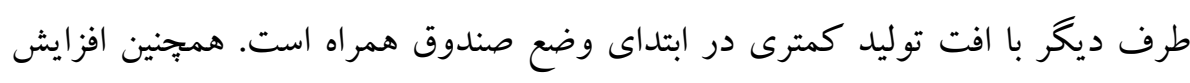
اوليه و كاهش نهايى تورم در اين حالت شديدتر است. لذا مىتوان از اين نمودارها

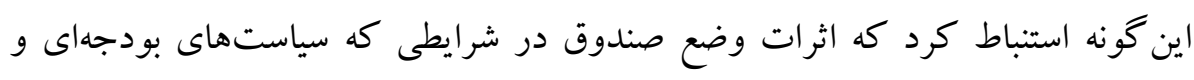
ارزى متفاوتى اتخاذ شوند، مى تواند نسبتاً متفاوت باشد. در نتيجه در كنار طراحى صنى صندوق

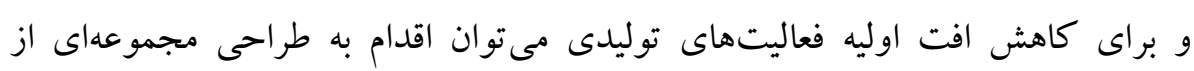

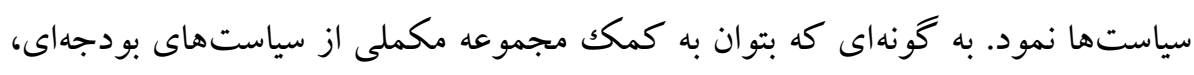
ارزى، مالى و نظارتى از شدت نوسانات كاست. 


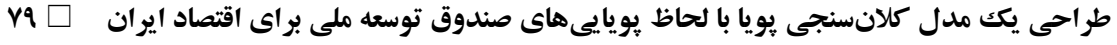
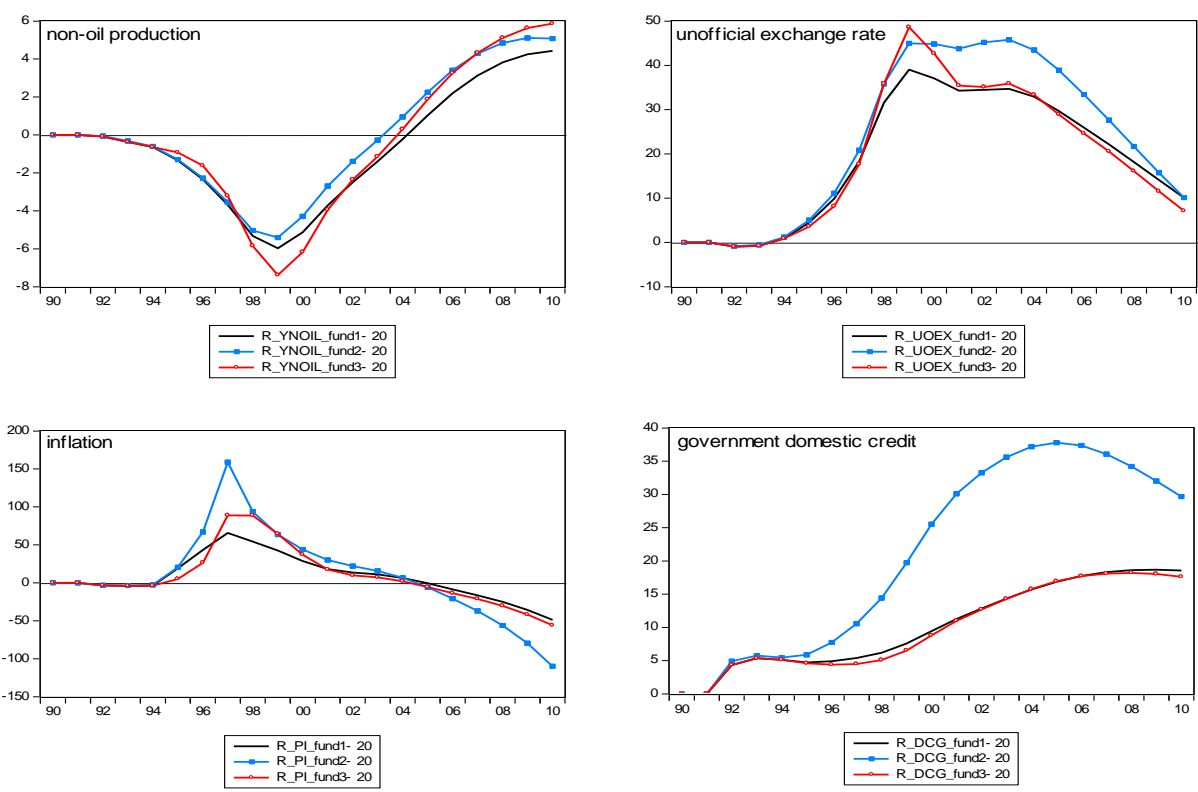

نمودارو. وضعيت متغيرهاى منتخب در سه سناريوى طراحى شده

مأخذ: يافته هاى تحقيق

\section{ه-r-r-r سناريو سهم شناور صندوق از در آمدهاى نفتى}

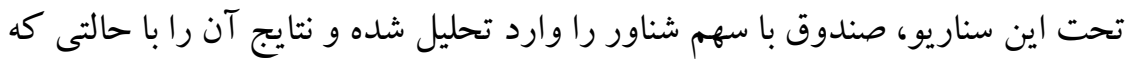
سهم صندوق از در آمدهاى دلارى صادرات نفت ثابت است، مورد مقايسه قرار مى گيرد. بر بر بـ اساس اطلاعات نمودار 9، خطوط - - وضعيت رشد متغيرها نسبت به حالت بدون صندوق در وضعيت صندوق بيست درصدى، خطوط •همين حالت را براى صندوق شناور و خطوط • در حالت صندوق بيست درصدى با اعمال قيد روى مخارج سرمايهاى دولت،

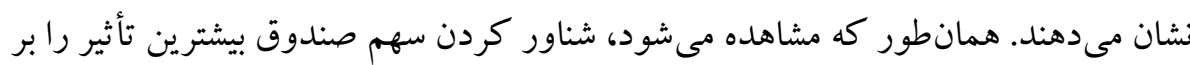
جلو گيرى از افت اوليه توليد پيس از طراحى صندوق دارد، از طرفى كمترين فشار اوليه تورمى نيز در اين حالت رخ مىدهد. كمترين نوسانات در نرخ ارز و خالص بدهى بخش

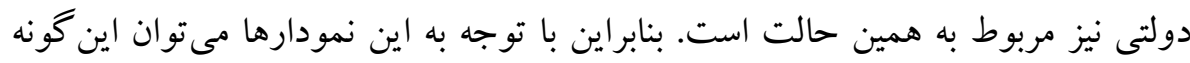

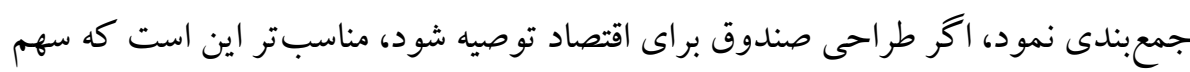

$$
\text { صندوق از در آمدهاى دلارى نفت به صورت شناور تنظيم شود. }
$$



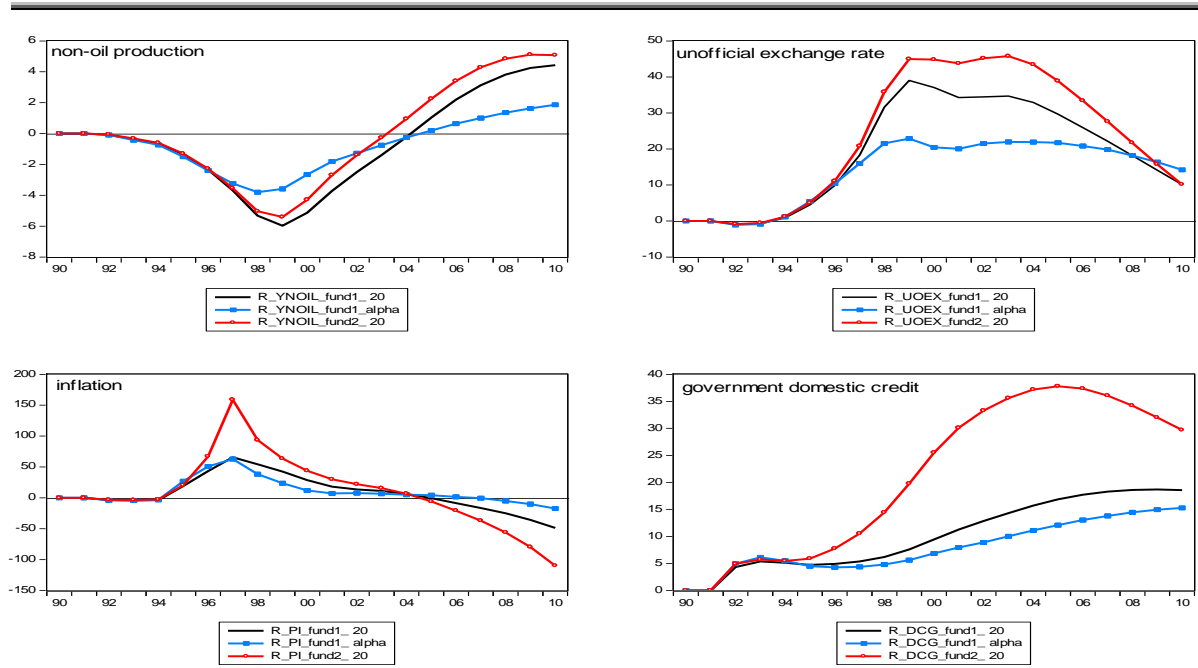

نمودار Y. وضعيت متغيرهاى منتخب در سه حالت

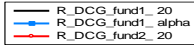

مأخذ: يافته هاى تحقيق

با توجه به توضيحات فوق مىتوان نتيجه گرفت كه تأسيس صندوق حداقل در كو تاهمدت آنطور كه انتظار مىرود، به بهبود متغيرهاى اقتصادى كمكك نخواهد به كرده بلكه آثار مثبت جنين سياستى در بلندمدت خود را نشان مىدهند. از طرفى در كوتاهمدت اين امكان وجود دارد كه با طراحى سياستهاى ارزى يا بودجهاى بتوان از افت اوليه سطح فعاليتهاى اقتصاد بر اثر وضع صندوق كاسته و بهبود عملكرد صندوق افزود. در كنار اين نكته، در طراحى صندوق جنانجه به جاى در نظر گرفتن سهم ثابتى از در آمدهاى دلارى نفت اين سهم متغير و شناور باشد، به كاهش بيامدهاى منفى كو تاهمدت كمكك مى شود.

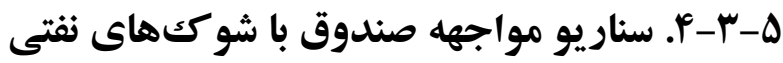

در اين بخش از تحليل، به ارزيابى نقش صندوق از منظر كنترل نوسانات در زمان وارد

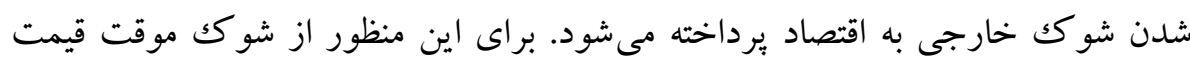

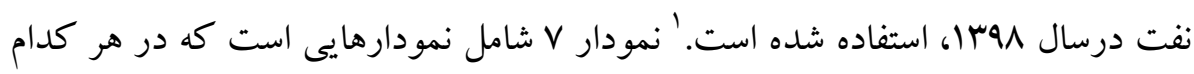
سه خط جدا گانه وجود دارد. خطوط - مربوط به زمانى است كه صندوق وجود ندارد.

ا ـ خاطر نشان مى شود، توابع واكنش در اين تحقيق، رشد متغيرها را نسبت به وضعيت بايـه خود آنها، يس از بروز شوك را نشان مىدهد. 
خطوط " مربوط به زمانى كه سهم صندوق بيست درصد در نظر گرفته مى شود و خطوط • مربوط به شرايطى كه سهم صندوق شناور در نظر گرفته مىشود. در هر مورد، رشد

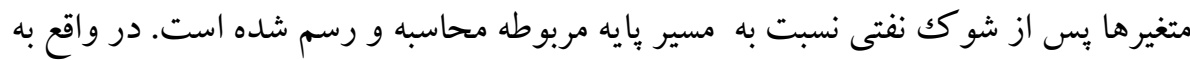
كمك اين نمودارها مىتوان عملكرد صندوق را در دو حالت سهم ثابت و شناور صندوق

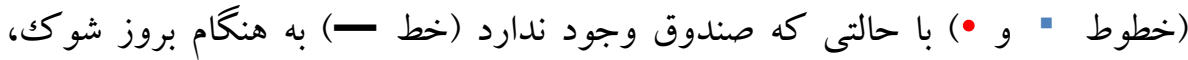
مقايسه كرد. همانطور كه مشاهده مىشود، با تداوم سازو كار فعلى صندوق توسعه ملى، زمانى كه شوكك نفتى (موقت) به اقتصاد وارد مى شود، وجود صندوق در كنترل نوسانات ناشى از شو كى تأثير جشمخيرى نمى تواند ايفا نمايد.

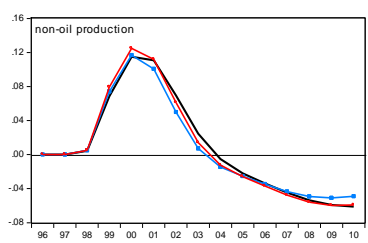

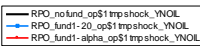

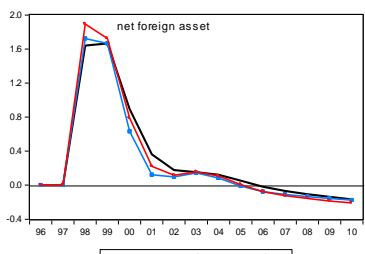

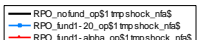

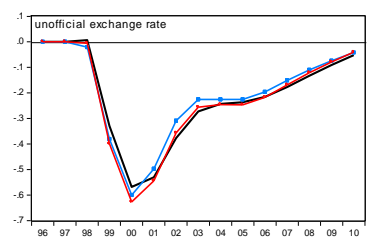

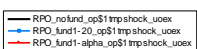

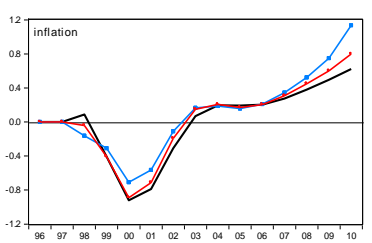

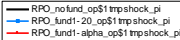
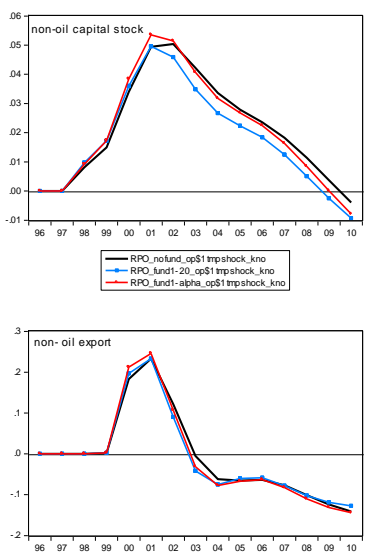

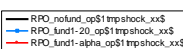

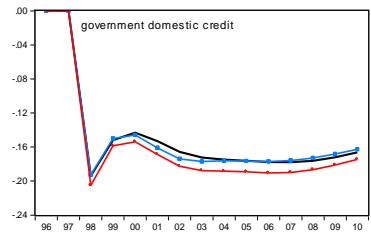

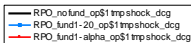
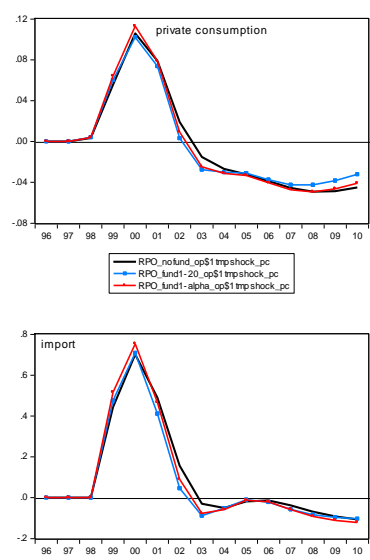

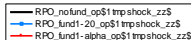

نمودار ^. شوك موقتى افزايش قيمت نفت و مقايسه عملكرد صندوق

مأخذ: يافته هاى تحقيق

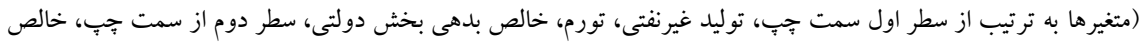

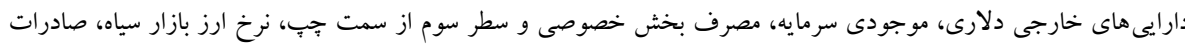


9. نتيجه كيرى و توصيههاى سياستى

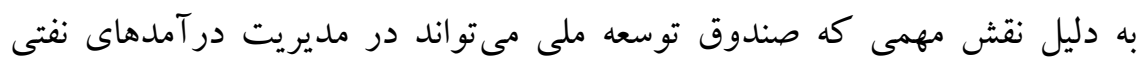

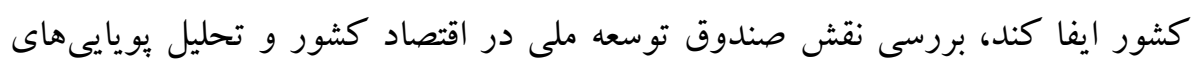

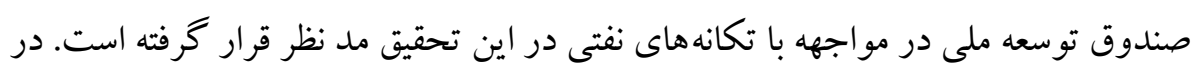
همين راستا هدف اصلى تحقيق حاضر مدلسازى صندوق توسعه ملى در اقتصاد ايران و

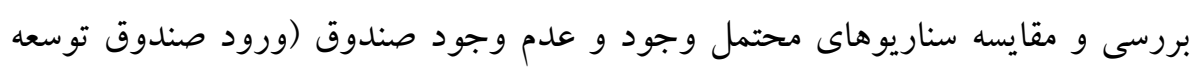

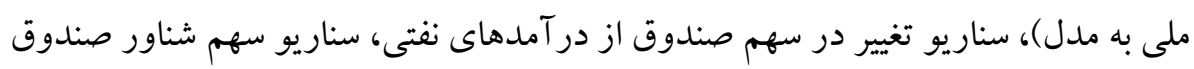

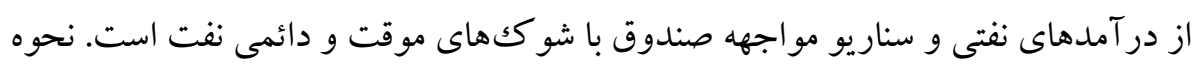

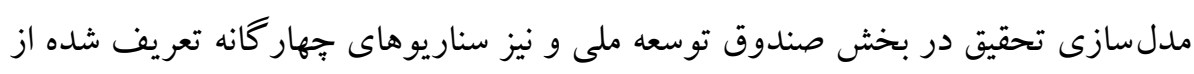

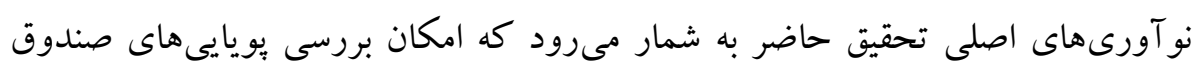
توسعه ملى را در اين تحقيق فراهم كرده است.

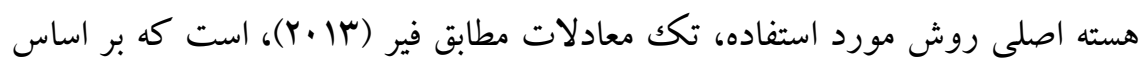

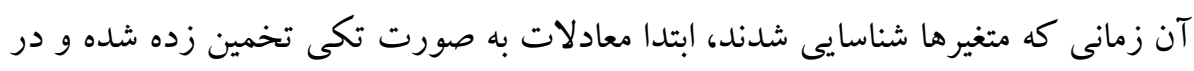

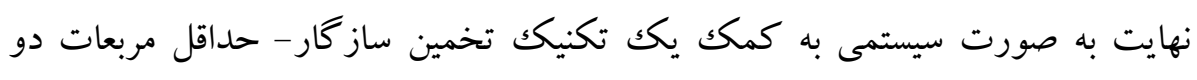

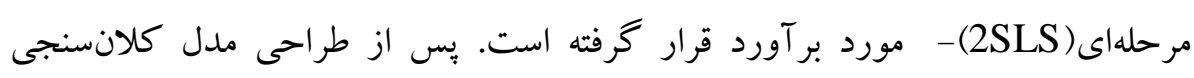

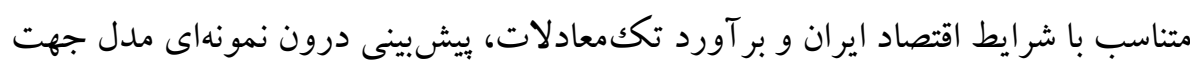

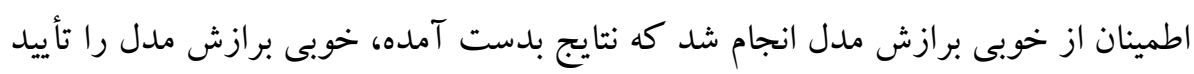
نمود. با عنايت به نتايج تجربى حاصل از تحقيق، خلاصه نتايج و توصيه هاى سياستى مبتنى

$$
\text { بر آن را مىتوان به صورت زير خلاصه كرد: }
$$

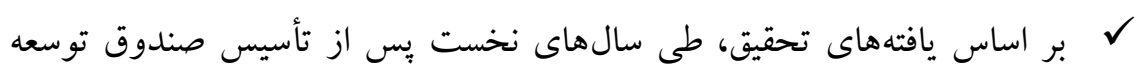

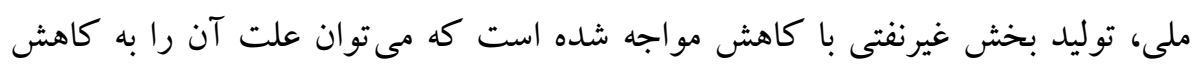
سهم فعاليت دولت به دليل كاهش سهم بودجه دولت از در آمدهاى نفتى و متناسب با با آن

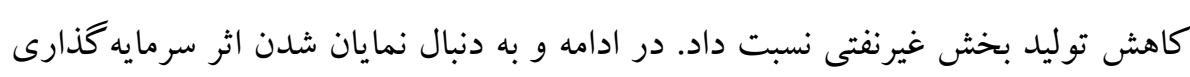
بخش خصوصى متأثر از تسهيلات اعطايى از سوى صندوق توسعه ملى، مى توان شاهد افزايش توليد بخش غيرنفتى در اقتصاد بود. 
ل با اضافه شدن صندوق به مدل، سهمى از درآمد دولت كه به بودجه واريز

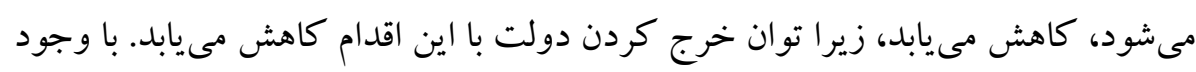

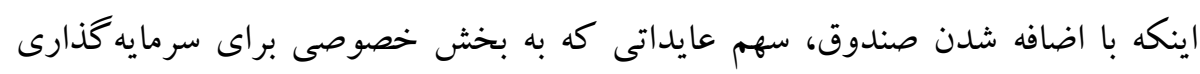

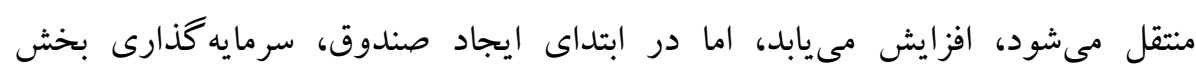

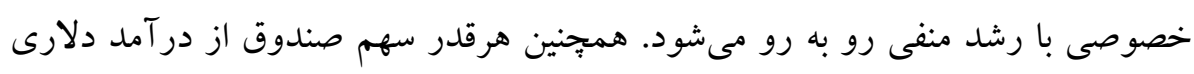

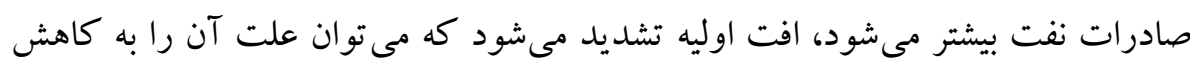
سهم فعاليت دولت به دليل كاهش سهم بودجه دولت از در آمدهاى نفتى نسبت داد كه

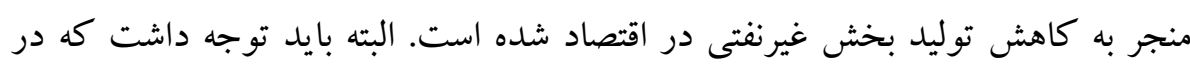

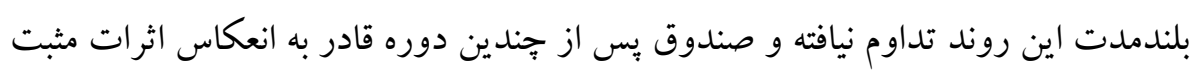
خود خواهد بود كه علت آن نمايان شدن اثر سرمايه گذارى بخش خصوص وصى متأثر از

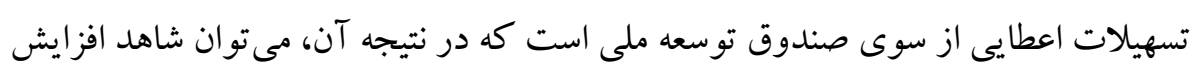
توليد بخش غيرنفتى در اقتصاد بود.

ل توصيه مىشود براى تعديل اين افت اوليه در كنار طراحى صندوق، دودئ دولت از

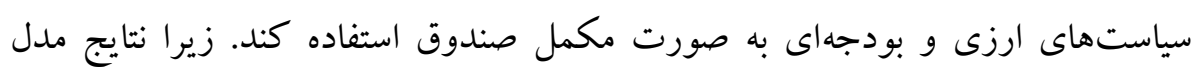
كلانسنجى نشان مىدهد، كاربست اين سياستها در تعديل اثرات منفى ابتداى دوره اضافه شدن صندوق مؤثر خو اهند بود.

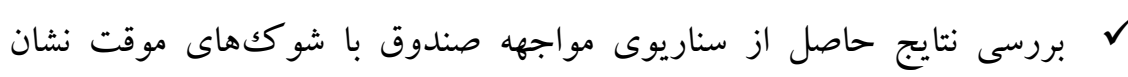
مىدهد، با تداوم سازو كار فعلى صندوق توسعه ملى، زمانى كه شوكى نفتى (موقت و و دائمى) به اقتصاد وارد مىشود، وجود صندوق در كنترل نوسانات ناشى از شوكى تأثير جشمخيرى نمى تواند ايفا نمايد.

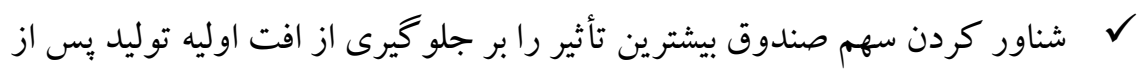

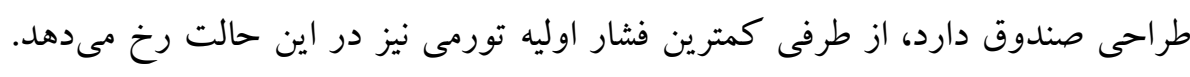
كمترين نوسانات در نرخ ارز و خالص بدهى بخش دولتى به سيستم بانكى نيز مربوط به به دارئ

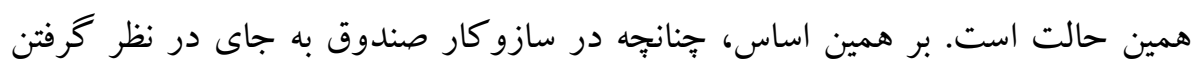

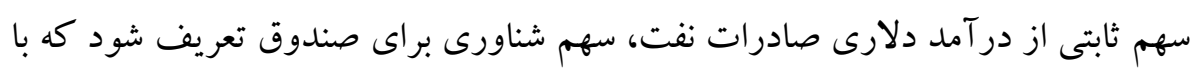
توجه به شرايط اقتصادى قابليت تغيير داشته باشد، نتايج مطلوبترى برى بر متغيرهاى كليدى برى 
مثل توليد و تورم حاصل مىشود. منظور از شناور كردن سهم صندوق توسعه ملى از درآمدهاى نفتى به معناى اتخاذ سياست ضدسيكلى در تخصيص تورد درد آمدهاى نفتى به صندوق توسعه ملى است. بنابراين توصيه اين تحقيق در راستاى بهبود سازو كار صندوق،

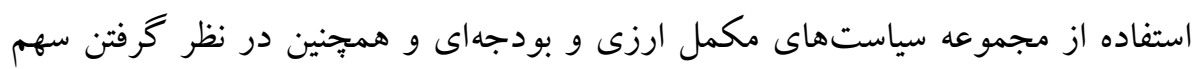
شناور صندوق از در آمدهاى نفتى است. 
- Abrishami, H., (1992), Preparation and Application of Macroeconometrics Models in Iran - A Comparative Study, Journal of Economic Research, Volume 31, Issue 46.

- Alleomran, R., Baradaranshoraka, H. (2008). A small continuous-Time macroeconometrics model of Iran (Structural Analysis). Iranian journal of management sciences (IAMS), 2(6), 235-263.

- Bahrami, J., (1998), Transfer of oil shocks in various foreign exchange regimes and the functioning of consolidation policies (Case Study: Iran), $\mathrm{PhD}$ Thesis, University of Tehran.

- Behboudi, D., (2008). The Role of the Exchange Reserve Account in the Stability of Government's Revenues in Iran (Using a CGE Model). Journal of Economic Research (Tahghighat- E- Eghtesadi), 43(1).

- Behboudi D, Motafkker Azad M A, Mamipour S. (2013), The Effects of Direct Distribution of Oil Revenues on GDP in Iran: A Dynamic General Equilibrium Approach. jemr.; 3 (10) :125-152

- Berg, Andrew, Rafael Portillo, Shu-Chun S. and Luis-Felipe Zanna, (2012), "Public Investment in Resource-Abundant Developing Countries" IMF Working Paper WP/12/274, International Monetary Fund.

- Burney, Nadeem A. \& Mohaddes, Kamiar \& Alawadhi, Ahmad \& AlMusallam, Marwa, (2018). "The dynamics and determinants of Kuwait's long-run economic growth," Economic Modelling, Elsevier, vol. 71(C), pages 289-304.

- Central Bank of Islamic Republic of Iran, (http://tsd.cbi.ir)

- Cherif, Reda, and Fuad Hasanov, (2012), "Oil Exporters' Dilemma: How Much to Save and How Much to Invest." IMF Working Paper WP/12/4, International Monetary Fund.

- Eifert, Gelb and Nils Tallroth, Managing Oil Wealth, Finance and Development, IMF, Vol. 40, No. 1, March 2003.

- Fair, R, C, (2013). "Macroeconometric Modeling". Harvard University Press, Business \& Economics. pp.2-32.

- Garshasbi A, (2016) Yusefi M. Assessment of International Sanctions on Iranian Macroeconomic Variables. jemr.; 7 (25) :129-182.

- Gylfason, Th, (2001). Nature, Power, and Growth, Scottish Journal of Political Economy, Vol 48, No5, pp.558-588.

- - Hansen, L. P. (1982), "Large Sample Properties of Generalized Method of Moments Estimators," Econometrica, 50, 1029-1054.

- Hosseininasab E, Abdullahi Haghi S, Naseri A, Agheli L. (2016), The Effects of Oil Boom and Oil Revenues Management on the Optimal Path of Iranian Macroeconomic Variables (Based on Dynamic Computable General Equilibrium). QJER.; 16 (2) :173-200.

- Islamic Parliament Research Center of The Islamic Republic Of IRAN, (2015), A Long Run Structural Macroeconometric Model for Iran, Economic Study (Macroeconomics and Modeling Group). 
- Islamic Parliament Research Center of The Islamic Republic Of IRAN, (2009), Macroeconomic management in oil exporting countries (Proceedings), ISBN: 978-964-8427-57-8

- Kader A., The Contribution of Oil Export to Economic Development A Study of Major Oil Exporting Countries, The American Economist, 1980, Vol. 20, pp. 46-51.

- Khiabani, N, (2003), A dynamic macroeconomic model for Iran: a new approach to econometrics, Monetary and Banking Research Center, ISBN: 964-6035-86-8.

- Kozminski, K., \& Baek, J. (2017). Can an oil-rich economy reduce its income inequality? Empirical evidence from Alaska's Permanent Fund Dividend. Energy Economics, 65, 98-104.

- Manzoor D, Taghipour A., (2016), A dynamic stochastic general equilibrium model for an oil exporting and small open economy: the case of Iran. Journal of Economic Research and Poilicies, 3.; 23 (75) :7-44

- Melina, Giovanni; Yang, Shu-Chun S. \& Zanna, Luis-Felipe (2014). "Debt Sustainility ,Public Investment and Natural Resources in Developing Countries: the DIGNAR International Monetary Fund, Washington I ,50 - Model," IMF Working paper, pp. 14 D.C.

- Noferesti, M, (2005). The Effect of Monetary and Foreign Currency Policies on the Iranian Economy in the Framework of a Large Macroeconometric Model. Journal of Economic Research (TahghighatE- Eghtesadi), 40(3).

- Sayadi, M., (2013), Comparative study of investment strategies and optimal management of the assets of the national wealth funds of the world, First National Conference in Petroleum and Economic Development, Tehran.

- Sayadi, M., Bahrami, J. (2015). Assessing the Effects of Oil Revenue Investment Policies on Macroeconomics Variables in Iran: The Stochastic Dynamic General Equilibrium Approach. Iranian Energy Economics, 4(16), 85-135. doi: 10.22054/jiee.2015.1895.

- Van der Ploeg, F., \& Venables, A. (2011). Natural Resource Wealth: The challenge of managing a windfall. The Economic Journal, 121(551), 130.

- www.ndf.ir 
ييوست ا. جداول متغيرهاى دورنزاو برونزاى مدل جدول ا. متغير هاى درونزاى مدرل مدل

\begin{tabular}{|c|c|c|}
\hline تعريف متغير & نام متغير & رديف \\
\hline 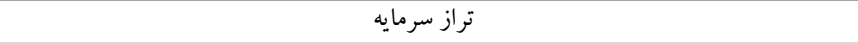 & bca $\$$ & 1 \\
\hline تراز كل (تغيير در ذخاير بين المللى)=تراز يرداختها (ميليون دلار) & bop\$ & r \\
\hline اعتبارات داخلى بخش دولت (ميليارد ريال) معادل خالص بدهى بخش دولتى به سيستم بانكى & $\operatorname{dcg}$ & $r$ \\
\hline هزينهاى مصرف نهايى بخش دولتى & gc & f \\
\hline سرمايه گذارى در بخش ساختمان & ibp & $\Delta$ \\
\hline سرمايه گذارى در ماشين آلات & ieqp & 9 \\
\hline تشكيل سرمايه ثابت ناخالص در ماشين آلات و ساختمان بخش دولتى & ig & $\checkmark$ \\
\hline تغييرات در موجودى انبار ت & inv & $\wedge$ \\
\hline تشكيل سرمايه ثابت ناخالص در ماشين آلات و ساختمان بخش خصوصى & ip & 9 \\
\hline ماليات بر درآمد م & it & 1. \\
\hline 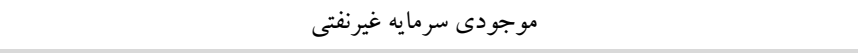 & kno & 11 \\
\hline اشتغال & 1 & ir \\
\hline نقدينگى & $\mathrm{mu}$ & ir \\
\hline خالص دارايىهاى خارجى سيستم بانكى(ميليارد ريال) & nfa & if \\
\hline 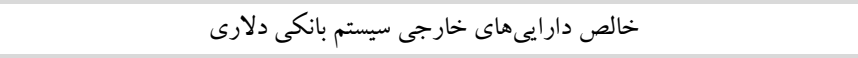 & nfa $\$$ & 10 \\
\hline تفاضل هزينه سرمايه گذارى خارجى و دريافت آن(خالص درآمد بهرهاى) به ميليون دلار & nsi\$ & 19 \\
\hline خالص صادرات غيرنفتى(خالص صادرات منهاى ارزش افزوده نفت) & $\mathrm{nx}$ & iv \\
\hline مصرف داخلى نفت & ocr 1 & 11 \\
\hline سرمايه گذارى دولت در نفت و كاز & ogsi & 19 \\
\hline در آمد ريالى نفت دولت & oi & r. \\
\hline صادرات دلارى نفت & ox\$ & M \\
\hline صادرات نفت تعديل شده به قيمت ثابت & oxr & rr \\
\hline سطح عمومى قيمتها & $\mathrm{p}$ & r \\
\hline هزينه هاى مصرفى خصوصى & $\mathrm{pc}$ & rF \\
\hline سرمايه گذارى بخش خصوصى & pi & $r \Delta$ \\
\hline نرخ بهره حقيقى & $\mathrm{rr}$ & rq \\
\hline 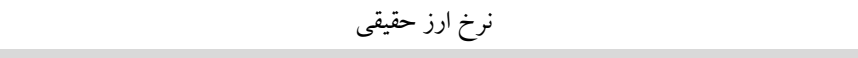 & ruoex & rV \\
\hline درآمد مالياتى كل دولت منهاى ماليات بر در آمد & tiadj & Үی \\
\hline كل درآمد دولت & $\operatorname{tr}$ & rq \\
\hline 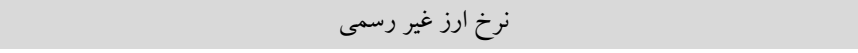 & uoex & r. \\
\hline نرخ بيكارى & ur & ו \\
\hline شاخص دستمزد & W & mr \\
\hline صادرات غيرنفتى به علاوه صادرات خدمات & $\mathrm{xx} \$$ & 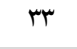 \\
\hline توليد ملى & $\mathrm{y}$ & MF \\
\hline توليد غيرنفتى & ynoil & ro \\
\hline واردات كالاها و خدمات & $\mathrm{Zz \$}$ & rq \\
\hline
\end{tabular}


جدول r. متغيرهاى برونزاى مدل

\begin{tabular}{|c|c|c|}
\hline تعريف متغير & 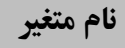 & 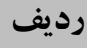 \\
\hline خالص اعتبارات بخش خصوصى & dcp & 1 \\
\hline ضريب استهلاكك & dep & r \\
\hline 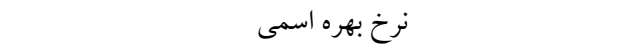 & ir & $r$ \\
\hline جمعيت فعال & laborf & r \\
\hline 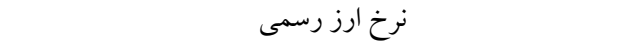 & oex & $\Delta$ \\
\hline قيمت دلارى نفت & op\$1 & 9 \\
\hline شاخص قيمت نفت در داخل & opil & $\mathrm{v}$ \\
\hline در آمد كل دولت منهاى درامد مالياتي و نفت & othr1 & $\wedge$ \\
\hline Add-factor & P_a & 9 \\
\hline جمعيت & pop & 1 . \\
\hline جز باقيمانده در تساوى تراز برداختها & u_bop\$ & 11 \\
\hline جز باقيمانده در تساوى خالص اعتبارات داخلى دولتى & u_dcg & ir \\
\hline جز باقيمانده در تساوى خالص دارايىهاى خارجى ريالى & u_nfa & ir \\
\hline جز باقيمانده در تساوى خالص صادرات & u_nx & if \\
\hline جز باقيمانده در تساوى در آمد نفت & u_oi & 10 \\
\hline Add-factor & uoex_a & 19 \\
\hline شاخص قيمت آمريكا & usp & IV \\
\hline نرخ بهره حقيقى اقتصاد آمريكا & usrr & 11 \\
\hline ارزش افزوده نفت & yoil & 19 \\
\hline \multicolumn{3}{|c|}{ توحيطى استفاده شده است. } \\
\hline
\end{tabular}




\title{
Designing a Dynamic Macroeconometric Model for the Iranian economy with Emphasizing on dynamics of the National Development Fund
}

\author{
Javid Bahrami ${ }^{1}$, Davoud Daneshjafari ${ }^{2}$ \\ Mohammad Sayadi ${ }^{3}$, Pegah Pasha ${ }^{4}$
}

Received: $2018 / 01 / 26$

Accepted: 2018/09/30

\begin{abstract}
Abstrtact
Oil Revenue Management (ORM) has always been one of the key challenges facing the oil rich developing countries. In this regard, the main objective of this paper is to provide a dynamic macroeconometric model adapted to the state of the Iranian economy. Also, the assessment of the dynamics of the National Development Fund (NDF) and its impact on macroeconomic variables are discussed. The results of the study, based on the out of sample and the four scenarios (the existence and absence of the NDF, the change in the share of the fund from oil revenues, the Fund's floating share of oil revenues, and the scenario of the fund exposure with temporary and permanent oil shocks) indicate that, The creation of a NDF in the short term will not improve the situation of macroeconomic variables, and the positive effects of such a policy will appear in the long run. The reason for this the private sector investment was time consuming and, consequently, the increase in non-oil sector production in the economy. Nevertheless, it is possible in the short term that by designing foreign exchange or budgetary policies, the initial downturn in the level of economic activity may be reduced by the stablization of the fund. Moreover, as in the mechanism of the fund, the floating share of oil revenues (adopting an anticyclical policy in allocating oil revenues to the fund) will help to reduce the negative consequences of shocks in the short run, because the lowest initial inflationary pressures, fluctuations in exchange rates and the net debt of the public sector occurs under this scenario.
\end{abstract}

Keywords: Macroeconometric Model, Simulation, National Development Fund JEL: E27, Q43, C51

1. Associate Professor of Economics, Allameh Tabatabei University,

Email: javid_bahrami@yahoo.com

2 . Assistant Professor of Economics, Allameh Tabatabei University,

Email: daneshjafari@gmail.com

3. Assistant Professor of Energy Economics, Kharazmi University, (Corresponding Author),Email: m.sayadi@khu.ac.ir

4. PhD Student of Economics, Allameh Tabatabei University,

Email: pasha.bamdad916@yahoo.com 